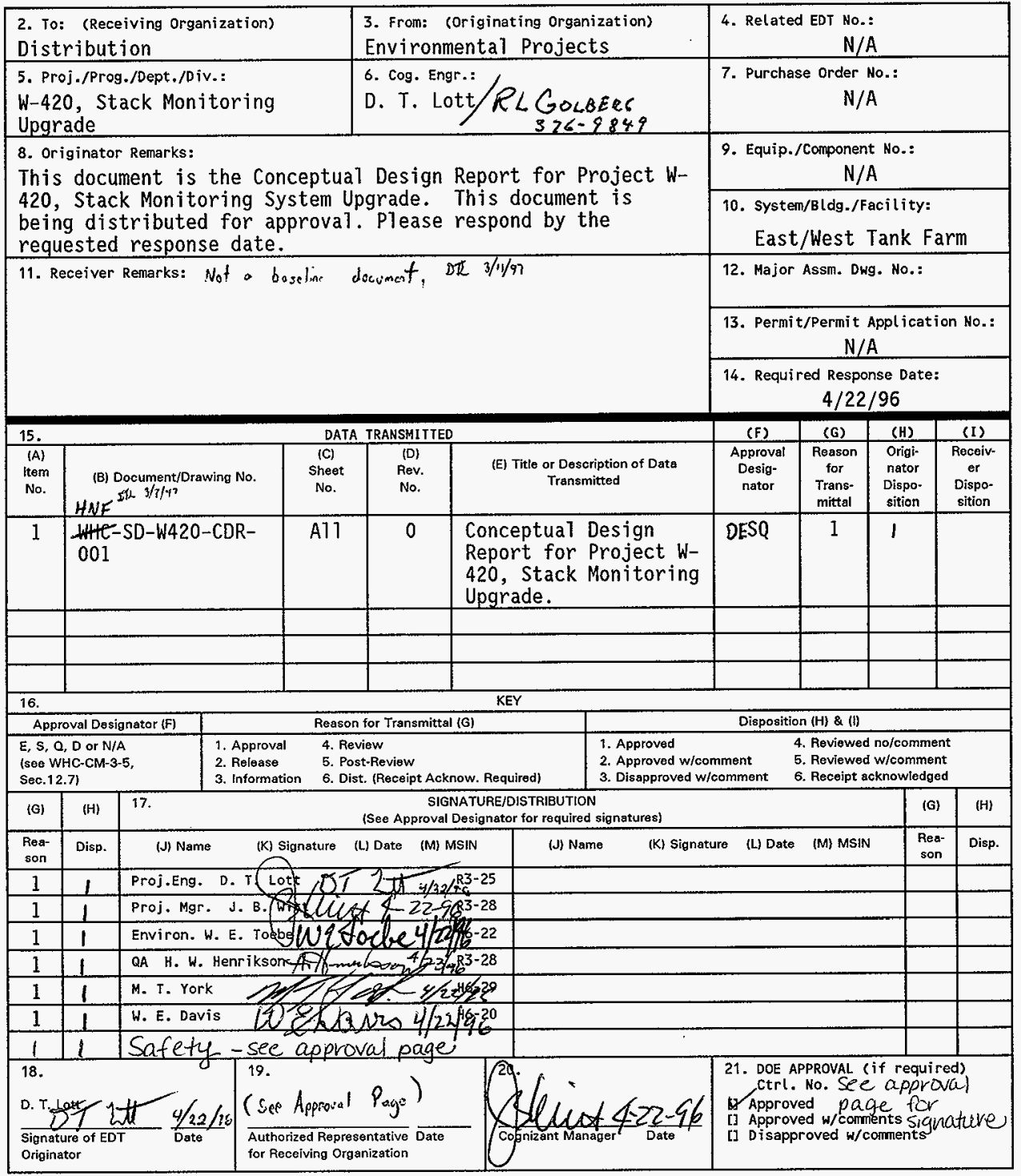




\section{Conceptual Design Report for Project W-420, Stack Monitoring Upgrade}

Darren T. Lott

Numatec Hanford Company, Richland, WA 99352

U.S. Department of Energy Contract DE-ACO6-96RL13200

EDT/ECN: 614748

Org Code: $8 \mathrm{C} 600$

B\&R Code: 39EW3120A
UC:

Charge Code: R4016

Tota1 Pages: 112113

aim $3 / 1197$

Key Words: Stack Monitoring Upgrades, GEMS, Gaseous Effluent Monitoring System, Project $W-420$, Exhaust Stacks, NESHAP

Abstract: This document provides the Conceptual Design for the upgrade of seven designated Tank Farm stacks to meet NESHAP Title 40, CFR, Part 61 , Sub-part $H$ requirements.

TRADEMARK DISCLAIMER. Reference herein to any specific commercial product, process, or service by trade name, tradenark, manufacturer, or otherwise, does not necessarily constitute or imply its endorsement, recomendation, or favoring by the United States Government or any agency thereof or its contractors or subcontractors.

Printed in the United States of America. To obtain copies of this document, contact: Document Control Services, P.0. Box 950, Mailstop H6-08, Richland WA 99352, Phone (509) 372-2420; Fax (509) 376-4989.
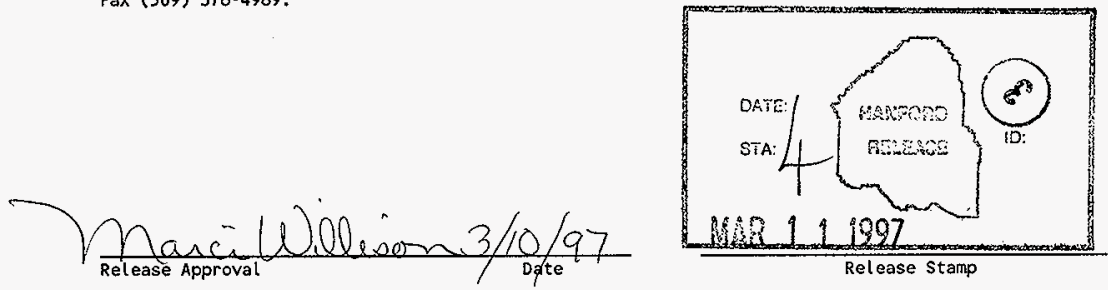
FNF-SD-W420-CDR-001, Rev, 0

\title{
CONCEPTUAL DESIGN REPORT STACK MONITORING SYSTEM UPGRADES PROJECT W-420
}

\author{
Prepared for \\ WESTINGHOUSE HANFORD COMPANY \\ Purchase Order MSJ-SBW-336070 \\ Report No. 961129-001 \\ Revision 0
}

September 1996

Prepared by

\section{ARES CORPORATION}

636 Jadwin Avenue Suite B

Richland, Washington 99352 


\title{
CONCEPTUAL DESIGN REPORT STACK MONITORING SYSTEM UPGRADES \\ PROJECT W-420
}

\author{
issued by \\ WESTINGHOUSE HANFORD COMPANY \\ for the
}

U.S. Department of Energy

Richland Operations Office

Richland, Washington

PREPARED BY: ARES Corporation

April 2, 1996

Date

\section{WESTINGHOUSE HANFORD COMPANY APPROVALS:}

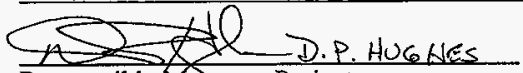

Responsible Manager, Projects

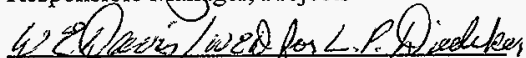

Manager, User/Sponsor Organization

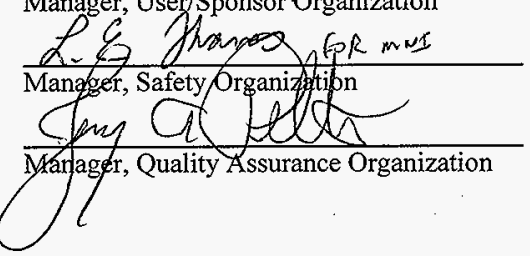

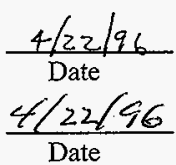

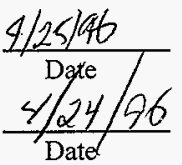

U.S. DEPARTMENT OF ENERGY APPROVAL:

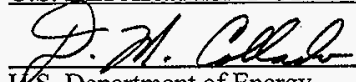

W.S. Department of Energy

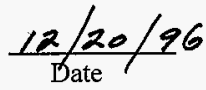




\section{CONCEPTUAL DESIGN REPORT \\ STACK MONITORING SYSTEM UPGRADES \\ PROJECT W-420}

Prepared for

\section{WESTINGHOUSE HANFORD COMPANY}

Purchase Order MSJ-SBW-336070

Report No. 961129-001

Revision 0

September 1996

Prepared by: Bruce D. Groth

Steven J. Weaver Approved by: $\frac{\text { Rabat } \& \text { Robert L. Fritz }}{O}$

Date: $10-10.96$ 
TABLE OF CONTENTS

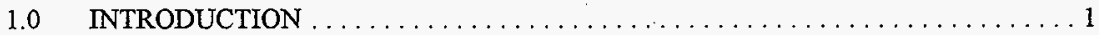

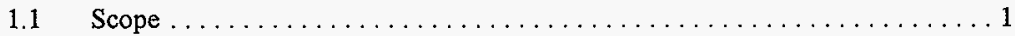

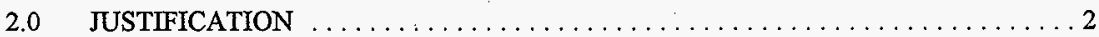

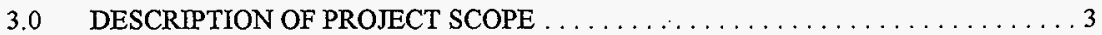

3.1 Gaseous Effluent Monitoring System $\ldots \ldots \ldots \ldots \ldots \ldots \ldots \ldots \ldots$

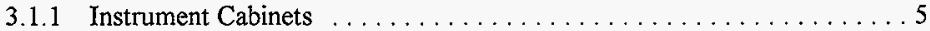

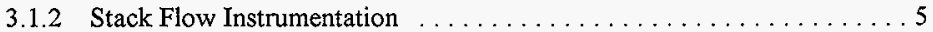

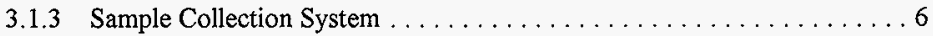

3.1 .4 Particulate Record Sampler ...................... 7

3.1.5 Particulate Beta-Gamma Continuous Monitor . . . . . . . . . . . 7

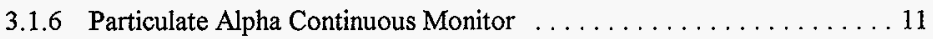

3.1 .7 Sample Flow Instrumentation $\ldots \ldots \ldots \ldots \ldots \ldots \ldots \ldots \ldots \ldots$

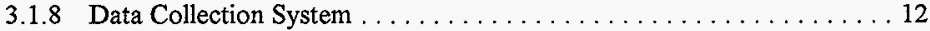

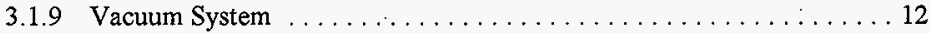

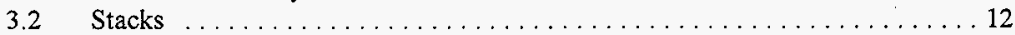

3.3 Utilities . . . . . . . . . . . . . . . . . . . . . . . . . . 14

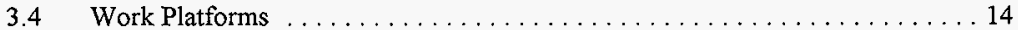

3.5 Detailed Installation Descriptions . . . . . . . . . . . . . . . . . 15

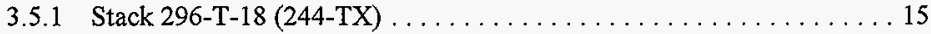

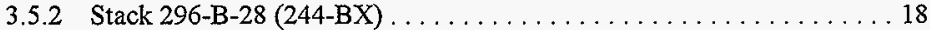

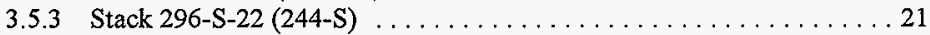

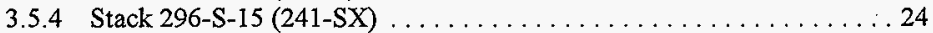

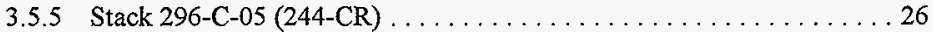

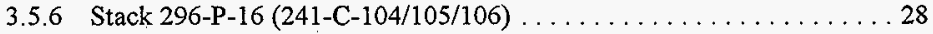

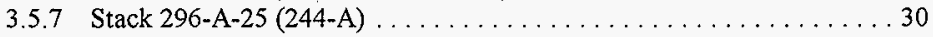

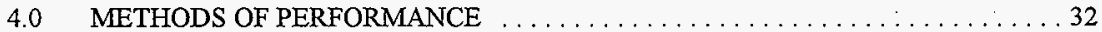

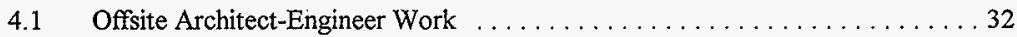

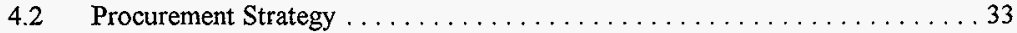

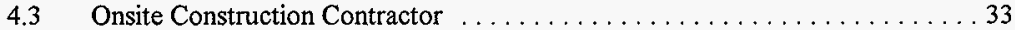

4.4 Work Planned for the Operating Contractor $\ldots \ldots \ldots \ldots \ldots \ldots \ldots \ldots \ldots \ldots$

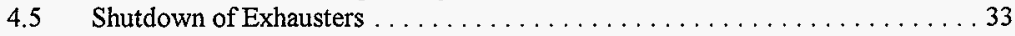

4.5.1 Stacks 296-A-25, 296-B-28, 296-C-05, 296-S-22, and 296-TX-18 . . . 34

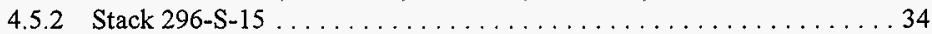

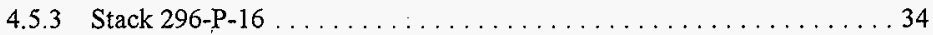




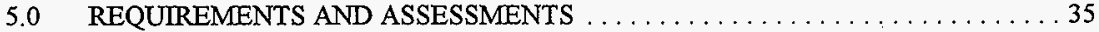

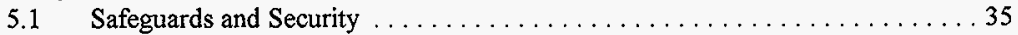

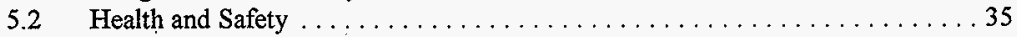

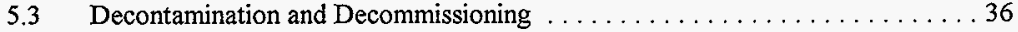

5.4 Maintenance and Operation Requirements ................... 36

5.5 Automatic Data Processing/Telecommunications $\ldots \ldots \ldots \ldots \ldots \ldots \ldots$

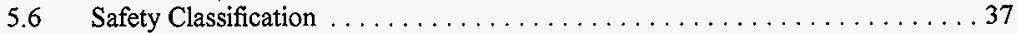

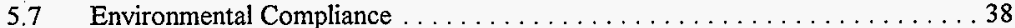

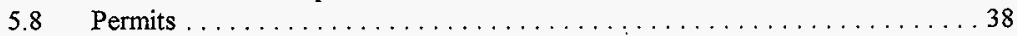

5.8.1 State and Federal Permits $\ldots \ldots \ldots \ldots \ldots \ldots \ldots \ldots \ldots \ldots \ldots$

5.8 .2 Hanford Site Permits . . . . . . . . . . . . . . . . . . . . 39

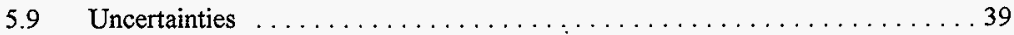

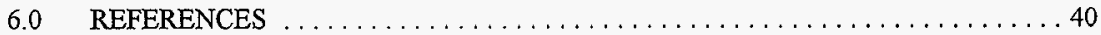

\section{APPENDICES}

Appendix A

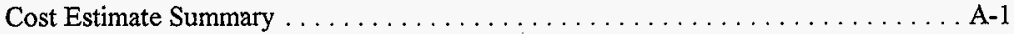

Appendix B

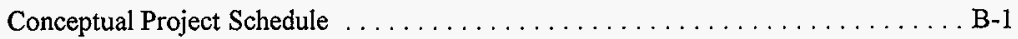

Appendix C

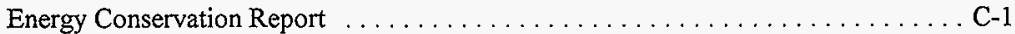

Appendix D

Economic Analysis and Life-Cycle Cost Analysis . . . . . . . . . . . . D-1 Appendix E

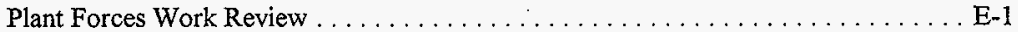

Appendix F

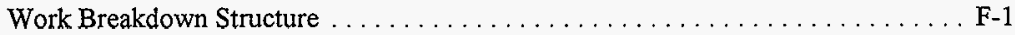

Appendix G

Outline Specifications $\therefore \ldots \ldots \ldots \ldots \ldots \ldots \ldots \ldots \ldots \ldots \ldots \ldots \ldots \ldots \ldots \ldots$

Appendix $\mathrm{H}$

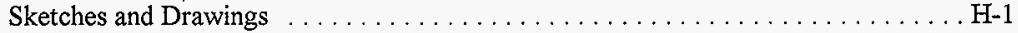
Appendix I

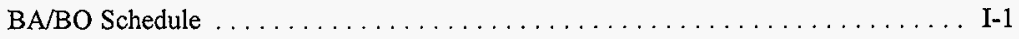




\section{TABLES}

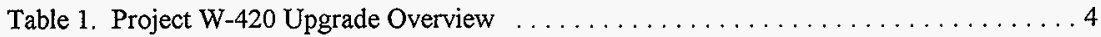

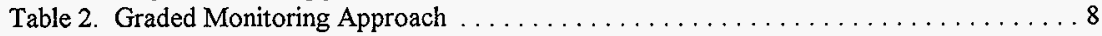

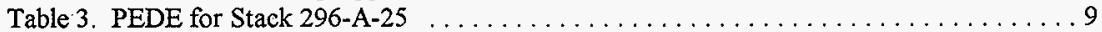

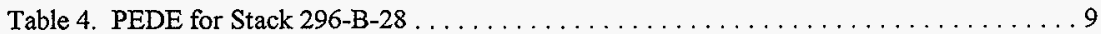

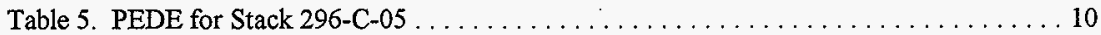

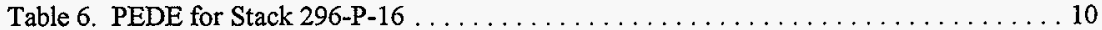

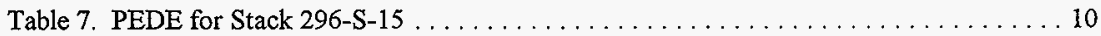

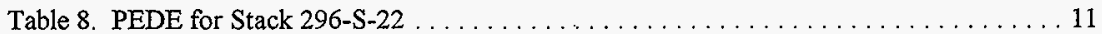

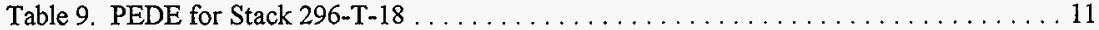

Table 10. Stack 296-T-18 Remote Alarms, Indications, and Interlocks (Existing) . . . . . . 18 


$\begin{array}{ll}\mathrm{cm} & \text { Centimeter } \\ \mathrm{ft} & \text { Foot } \\ \mathrm{cfm} & \text { Cubic feet per minute } \\ \mathrm{fpm} & \text { Feet per minute }\end{array}$

\section{ACRONYMS}

A-E

ANSI

ASHRAE

ASTM

CAM

CASS

CDR

DCRT

DOH

EDE

FONSI

GEMS

HPT

JSA

LCCA

NEPA

NESHAP

NOC

PEDE

SSC

SST

WHC

Architect-Engineer

American National Standards Institute

American Society of Heating, Refrigerating, and Air-Conditioning

Engineers

American Society for Testing and Materials

Continuous Air Monitor

Computer Automated Surveillance System

Conceptual Design Report

Double Contained Receiver Tank

Washington State Department of Health

Effective Dose Equivalent

Finding of No Significant Impact

Gaseous Effluent Monitoring System

Health Physics Technician

Job Safety Analysis

Life-Cycle Cost Analysis

National Environmental Policy Act

National Emission Standards for Hazardous Air Pollutants

Notice of Construction

Potential Effective Dose Equivalent

Systems, Structures, or Components

Single-Shell Tank

Westinghouse Hanford Company

\section{TRADEMARKS}

G2 ${ }^{\mathrm{TM}}$ software $\quad$ Registered trademark of Gensym Corporation, Cambridge, MA. 


\subsection{INTRODUCTION}

Project W-420, "Stack Monitoring System Upgrades," will upgrade seven 200 Area Tank Farm stacks to meet National Emission Standards for Hazardous Air Pollutants (NESHAP), Title 40, CFR, Part 61, Subpart H, requirements. Replacement Gaseous Effluent Monitoring Systems (GEMS) will be fabricated and installed to upgrade the exhaust monitoring capabilities in the Hanford Site 200 East and West Tank Farms. The facilities that will have their associated monitoring capabilities upgraded are listed below.

- $\quad$ Four Double Contained Receiver Tanks (DCRTs) which are small (approx. 25,000 gallon) tanks used for transferring liquid radioactive wastes. These facilities are designated as 244-A, 244-BX, 244-S, and 244-TX. They are normally maintained in an empty (except for the unpumpable heel) status when a transfer is in progress. These DCRTs will be used for saltwell pumping through 1999 and may be used for waste retrieval through 2024 . Upgrades to the exhaust system will support these missions.

- The 244-CR Vault is now used primarily as a receiver tank for transferring liquid radioactive wastes from the 241-C Tank Farm. There are four tanks in the vault of which two are isolated and inactive, one is used as a drain tank, and one is in active service. The 244-CR Vault will be used for saltwell pumping through 1999 and may be used for waste retrieval through 2018 . Upgrading the exhaust system will support this mission.

- The 241-SX Exhauster is commonly referred to as the sludge cooler as its function is to cool the solids left in the tanks in the 241-SX Tank Farm following saltwell pumping. As the radioactive waste decays, the heat generation rate slowly decreases and the system will not be required after 2015 . The possibility exists that the need for this system may be removed even earlier, depending on the results of waste analysis.

- The exhauster for Tanks 104-C, 105-C, and 106-C is used to maintain their temperature within specification. In 1998, Tank 106-C will have a separate exhauster installed and then the waste will be partially retrieved. The exhauster for Tanks 104-C and 105-C is expected to remain in operation through 2010.

\subsection{Scope}

Project W-420 will upgrade the monitoring systems on the following exhaust stacks:

- 296-A-25, 244-A DCRT,

- 296-B-28, 244-BX DCRT,

- 296-C-05, 244-CR Vault, 
- $\quad$ 296-S-22, 244-S DCRT,

- 296-T-18, 244-TX DCRT,

- 296-S-15, 241-SX Tank Farm, and

- 296-P-16, 241-104C/-105C/-106-C Single Shell Tank Exhauster Stack.

The efforts necessary to implement Project W-420's stack monitor upgrades will include:

- Preparation of procurement specifications,

- Procurement of new stack monitors and associated probes,

- Preparation of the installation design, including modification of the existing stacks as necessary,

- Removal and disposal of the existing stack monitors and any removed stack sections,

- Installation of the stack monitors, stack probes, and sample transport piping, including necessary modifications to the existing stacks,

- Installation of work platforms to provide for equipment monitoring and access to the sample probe locations for operations and maintenance workers, and

- Completion of electrical interfaces with existing alarms and interlocks.

Project W-420 is a 1999 Line Item Project with an estimated total project cost of $\$ 3,222,853$.

\subsection{JUSTIFICATION}

Stack monitoring requirements for radionuclides are based on the potential for radionuclide emissions for that release point. If it is determined that an exhaust stack has the potential (i.e., with no emission control device in place) to provide an Effective Dose Equivalent (EDE) of greater than $0.1 \mathrm{mrem} / \mathrm{yr}$ to any member of the general public, then monitoring must be performed in accordance with NESHAP (40 CFR 61, Subpart H, "National Emission Standards for Emissions of Radionuclides Other Than Radon From Department of Energy Facilities").

Compliance with NESHAP regulations required assessment and upgrade of those emission points which have the potential to exceed the specified limits. An assessment for each stack in the 200 Area Tank Farms was performed and the results shown in Westinghouse Hanford Company (WHC) document WHC-SD-WM-EMP-03 1, Tank Farm Stacks NESHAP Designation Determinations (Crummel 1996). This initial assessment was performed using conservative methods and determined that sixteen stacks have the potential to exceed the $0.1 \mathrm{mrem}$ limit. Those stacks that could exceed 0.1 mrem were considered "designated," and those that did not were considered "non-designated."

Revision 1 of the WHC-SD-WM-EMP-031 (Crummel 1996) applied less conservative methods 
and newly obtained information. As a result, five of the sixteen originally designated stacks were reassessed to be non-designated. In addition, one of the originally non-designated stacks was reassessed to be designated. The result was a net change in the total number of designated Tank Farm stacks to 12 .

Revision 2 of WHC-SD-WM-EMP-031 (Crummel 1996) incorporated assessments for three additional Tank Farm stacks not addressed in Revision 1. These three stacks were determined to be non-designated. Reassessment of five additional stacks was also performed in Revision 2. Of these stacks, two were determined to be non-designated (AY-AZ stacks 296-A-17 and 296-P26), two remained designated (SX Tank Farm stack 296-S-15 and the 244-S DCRT stack 296-S-22), and the fifth (244-A DCRT stack 296-A-25) was determined at its pre-revision 1 status of designated. The total number of designated Tank Farms stacks assessed in Revision 2, was, therefore, 11 .

Of these 11 designated stacks documented in WHC-SD-WM-EMP-03 1, Revision 2 (Crummel 1996), two of the stack monitoring systems have been determined to be compliant (296-A-22 and 296-U-11), one will be upgraded with a new generic effluent monitoring system currently under development (296-A-40), and one will undergo minor modification and a request made for equivalency (296-A-12). Subsequently, the seven stacks listed in the Section 1.1 of this report will require upgrades according to the requirements in NESHAP, Title 40, CFR, Part 61, Subpart H, via Project W-420.

\subsection{DESCRIPTION OF PROJECT SCOPE}

The Functional Design Criteria for Project W-420, Stack Monitoring Upgrade, WHC-SDW420-FDC-001 (Lott 1996) defines the design criteria to which the GEMS must conform. A summary of the work to be performed is shown in Table 1. 
Table 1. Project W-420 Upgrade Overview

\begin{tabular}{|c|c|c|c|c|c|c|c|}
\hline racility & $\begin{array}{l}\text { Remove } \\
\text { oxisting } \\
\text { Montor }\end{array}$ & $\begin{array}{l}\text { Renove } \\
\text { Enisting } \\
\text { Stak }\end{array}$ & 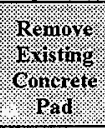 & Modincitions & $\begin{array}{l}\text { Wnstall } \\
\text { Concrote } \\
\text { pads }\end{array}$ & 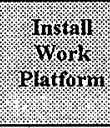 & Nonition \\
\hline $244-A$ & $Y$ & $\mathrm{Y}$ & $Y$ & $\mathrm{R}$ & $\mathrm{Y}$ & $Y$ & $Y$ \\
\hline 244-BX & $Y$ & $Y$ & $\mathrm{~N}$ & $\mathrm{R}$ & $\mathrm{Y}$ & $Y$ & $Y$ \\
\hline 244-CR & $\mathrm{Y}$ & $\mathrm{N}$ & $\mathrm{Y}$ & $M$ & $\mathrm{Y}$ & $Y$ & $\mathrm{Y}$ \\
\hline $244-\mathrm{S}$ & $Y$ & $Y$ & $\mathrm{~N}$ & $\mathrm{R}$ & $\mathrm{Y}$ & $Y$ & $\mathrm{Y}$ \\
\hline 244-TX & $Y$ & Y & $\mathrm{N}$ & $\mathrm{R}$ & $Y$ & $\mathrm{Y}$ & $Y$ \\
\hline $241-C$ & $Y$ & $Y$ & $\mathrm{~N}$ & $\mathrm{R}$ & $\mathrm{Y}$ & $Y$ & $\mathrm{Y}$ \\
\hline 241-SX & $Y$ & $Y$ & $\mathrm{Y}$ & $\mathrm{R}$ & $\mathrm{Y}$ & $Y$ & $Y$ \\
\hline
\end{tabular}

$Y=$ yes $\quad$ Notes: 1) $M=$ modify existing,

$\mathrm{N}=$ no $\quad$ 2) $\mathrm{R}=$ replace

\subsection{Gaseous Effuent Monitoring System}

A GEMS will be installed at each exhaust stack to monitor and trend the concentration of radioactive materials released to the environment. The system will extract a representative sample; measure and totalize stack velocity and flow rate; measure, control, and totalize sample flow rates; and monitor the sample flow to determine air emissions. Each system shall contain the following equipment as required for the individual stack:

- Instrument Cabinets,

- Stack Flow Instrumentation,

- Sample Collection System,

- Particulate Record Sampler,

- Particulate Beta-Gamma Continuous Monitor,

- Particulate Alpha Continuous Monitor,

- Sample Flow Instrumentation,

- Data Collection System, and

- Vacuum System.

Design of the air monitoring and sampling systems for Project $\mathrm{W}-420$ is based on specifications provided by WHC-S-0400, Procurement Specification for the Gaseous Effluent Monitoring System (White 1995). This specification establishes the requirements for design and fabrication of a generic GEMS and will be modified to meet stack-specific requirements for this project. The 
following provides a general overview of the equipment and details of the various components. In general, the GEMS consists of in-stack sample probes, three instrument cabinets that house associated electronics and sampling systems, and in-stack instrumentation (humidity, temperature, and flow).

\subsubsection{Instrument Cabinets}

The air sampling and monitoring system is provided in three separate cabinets: a sampler cabinet, an electronics cabinet, and a pump cabinet. The cabinets are weatherproof and maintain a controlled environment as required for equipment and instrumentation.

The electronics and pump cabinets contain the support equipment for the sampling system and are provided by the vendor on a 34 inch $(86 \mathrm{~cm})$ by 70 inch $(178 \mathrm{~cm})$ skid with a weather shield. The sampler cabinet contains the equipment to analyze the air sample taken from the stack and is mounted on a platform adjacent to the exhaust stack at the sample probe location. This location is based on locating the sampler cabinet as close to the sample source as practical to minimize the loss of sample particles in the sample transport line between the probe assembly and the record sampler. The electronics and pump cabinet skids are located as close as practical to the sampler cabinet.

The following data displays are provided on the local cabinets:

- Stack flow rate,

- Stack gas temperature,

- Individual sampler/monitor flow rate, and

- Other indications and readouts as determined appropriate by the vendor, with customer approval. An alarm for high radiation consisting of a ringing bell and rotating red beacon is located on top of the electronics cabinet.

\subsubsection{Stack Flow Instrumentation}

Airflow sensing probes are provided to monitor stack flow rate. The probes are mounted on removable flange assemblies to allow removal for inspection and maintenance. The sensing probes are positioned perpendicular to the direction of flow and are either selfaveraging pitot or thermal anemometer type probes. If a pitot-type probe is used to measure flow rate, a temperature probe is also installed in the stack to provide temperature information necessary to interpret the flow rate. Design of the airflow sensing probes and temperature probes (if required) will be performed by the GEMS vendor, based on the stack-specific requirements in the procurement specification. 
The airflow sensing probes are positioned in each stack in accordance with the appropriate 40 CFR 60, Appendix A method. Airflow sensing and sample probes are located in the same plane for Stacks 296-C-5, 296-S-15, and 296-P-16 as these stacks are greater than 12 inches in diameter. Stack velocity is measured downstream from the sample probes for Stacks 296-A-25, 296-T-18, 296-B-28, and 296-S-22 because these stacks are less than 12 inches in diameter and locating both probes in the same sample plane would block a significant portion of the cross section and could cause inaccurate measurements.

Calibration ports are necessary to allow periodic flow rate verification. The calibration ports are positioned in accordance with the appropriate 40 CFR 60, Appendix A method, to prevent encountering obstructions from other probes. Calibration ports will be provided on new Stacks 296-A-25, 296-S-15, 296-P-16, 296-B-28, 296-S-22, and 296-T18. For stack 296-C-05, modifications to the existing stack will be made to add the necessary calibration ports.

\subsubsection{Sample Collection System}

The transport piping and sample collection probes for sampling particulate radionuclides are designed and fabricated by the GEMS vendor in accordance with the requirements of document WHC-SD-EN-TI-288, Functional Requirements Document for Measuring Emissions of Airborne Radioactive Materials (Criddle 1994) and the appropriate procurement specification. The probes are mounted on removable flange assemblies to allow for inspection and maintenance.

Sample collection probes are positioned in each stack in accordance with American National Standards Institute (ANSI) N13.1 and 40 CFR 60, Methods 1 and 1A. The sample extraction location will be qualified according to the performance criteria specified in WHC-SD-SD-WM-TI-288 (Criddle 1994). Qualification of the sample location for the new stacks can be done by mocking up the stack in the shop and performing the test prior to delivery. For the stacks being modified, the test will need to be performed after stack modifications have been performed.

The sampler cabinets are mounted directly on the work platforms adjacent to the exhaust stacks. This design is utilized to minimize the loss of particulates in the sample lines by assuring sample lines are as short as practical, the number of bends are minimized, and horizontal runs of sample lines are avoided. The size of the transport line for each stack will be determined by the vendor. The sampler cabinet is heated to maintain the electronics at the proper operating temperature and to prevent condensation from forming in the sample lines. In the sampler cabinet, the sample flow stream is split and one stream flows to the record sampler and the other flows to the continuous in-line beta-gamma 
sample head. The flow rate of each sample stream is controlled separately.

The sample transport lines are recombined in the Sampler cabinet and routed to the pump cabinet where the vacuum pumping sources are located. Sample return piping is provided from the pump cabinet to return the extracted sample to the stack. The size of the return line for each stack will be determined during final design (normally $1 / 2$ inch).

Sample probe, sample transport piping, and sample return piping will be fabricated from type 316 stainless steel. All tubing is seamless construction with material composition per American Society for Testing and Materials (ASTM) A269.

\subsubsection{Particulate Record Sampler}

The particulate record sampler is located in the sampler cabinet. The particulate record sampler collects a sample of particles onto a standard 47 millimeter $(\mathrm{mm})$ membrane filter paper for future radionuclide analysis at a laboratory. A record sampler is required to meet the requirements of 40 CFR 61 Subpart $H$ which requires that "all radionuclides which could contribute greater than 10 percent of the potential effective dose equivalent for a release point shall be measured."

Performance of the particulate record sampler shall be verified and documented by (in order of preference): 1) a field acceptance test, 2) laboratory wind tunnel testing, or 3) the verified model (Criddle 1994). Performance requirements for the record sampler and sample probe are as specified in WHC-S-0400 (White 1995) and WHC-SD-W420-FDC001 (Lott 1996).

\subsubsection{Particulate Beta-Gamma Continuous Monitor}

The particulate beta-gamma continuous monitor in-line sample head is located in the sampler cabinet. The counting electronics are located in the electronics cabinet. A local alarm on top of the electronics cabinet is provided for stack high radiation. The alarm includes a ringing bell and rotating red beacon. Auxiliary contacts are provided for two remote indicators, if desired; one for high radiation and one for continuous air monitor (CAM) failure.

The criteria for the need of a continuous on-line beta-gamma monitor is the graded approach to the application of sampling and monitoring outlined in WHC-SD-WM-TI-288 (Criddle 1994). This graded approach is reproduced below in Table 2 where it can be seen that real-time monitoring is required for Potential Effective Dose Equivalents (PEDE) greater than $1.0 \mathrm{mrem} / \mathrm{yr}$. 
Table 2. Graded Monitoring Approach

\begin{tabular}{|c|c|c|}
\hline 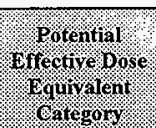 & Required Monitoring and Sampling Aralysis & 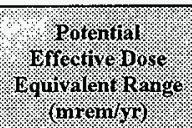 \\
\hline 1 & $\begin{array}{l}\text { Continuous extractive sampling for a record of emissions and in-line, } \\
\text { real-time monitoring with alarm capability; consideration of separate } \\
\text { accident monitoring system. }\end{array}$ & $>1.0$ \\
\hline 2 & $\begin{array}{l}\text { Continuous extractive sampling for record of emissions, with } \\
\text { retrospective, off-line periodic analysis. }\end{array}$ & $>0.1$ and $\leq 1$ \\
\hline 3 & Periodic confirmatory extractive sampling and off-line analysis. & $>0.001$ and $s 0.1$ \\
\hline 4 & $\begin{array}{l}\text { Annual administrative review of facility used to confirm absence of } \\
\text { radioactive materials in forms and quantities not conforming to prescribed } \\
\text { specifications and limits. }\end{array}$ & $\$ 0.0001$ \\
\hline
\end{tabular}

Six of the seven stacks within the scope of Project W-420 have PEDEs greater than 1.0 $\mathrm{mrem} / \mathrm{yr}$ of which the majority are beta-gamma emitters. For this reason, a continuous beta-gamma monitor is required for the following stacks: 296-A-25, 296-B-28, 296-C-05, 296-P-16, 296-S-15, and 296-S-22. However, to provide flexibility for process changes such as the use of the DCRTs for retrieval, a continuous beta-gamma monitor is also recommended for Stack 296-T-18. Tables 3 through 9 contain information from WHCSD-WM-EMP-031 (Crummel 1996) on the total PEDEs for the seven stacks and the individual radionuclides which provide greater than one percent of the total PEDE. 
Table 3. PEDE for Stack 296-A-25

\begin{tabular}{|c|c|c|c|}
\hline ( & . Emiter &.$\% \mathrm{ODDH}$ & 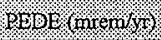 \\
\hline Cs-137 & alpha & $71.1 \%$ & 3.97 \\
\hline $\mathrm{Pu}-239 / 240$ & alpha & $23.5 \%$ & 1.31 \\
\hline Am-241 & alpha & $2.8 \%$ & 0.16 \\
\hline $\mathrm{Pu}-238$ & alpha & $1.1 \%$ & 0.06 \\
\hline Others $(<1 \%)$ & N/A & $1.5 \%$ & 0.08 \\
\hline Total & N/A & $100 \%$ & 5.58 \\
\hline
\end{tabular}

Table 4. PEDE for Stack 296-B-28

\begin{tabular}{|c|c|c|c|}
\hline Radienudlide & Enitter TYpe & $\%$ PEVE & 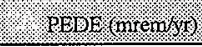 \\
\hline Cs-137 & beta-gamma & $37.6 \%$ & 0.975 \\
\hline Am-241 & alpha & $37.4 \%$ & 0.969 \\
\hline Pu-239/240 & alpha & $10.6 \%$ & 0.275 \\
\hline $\mathrm{Sr}-89 / 90$ & beta-gamma & $9.0 \%$ & 0.233 \\
\hline $1-129$ & beta-gamma & $4.3 \%$ & 0.111 \\
\hline Others $(<1 \%)$ & N/A & $1.1 \%$ & 0.027 \\
\hline Total & $N / A$ & $100 \%$ & 2.590 \\
\hline
\end{tabular}


Table 5. PEDE for Stack 296-C-05

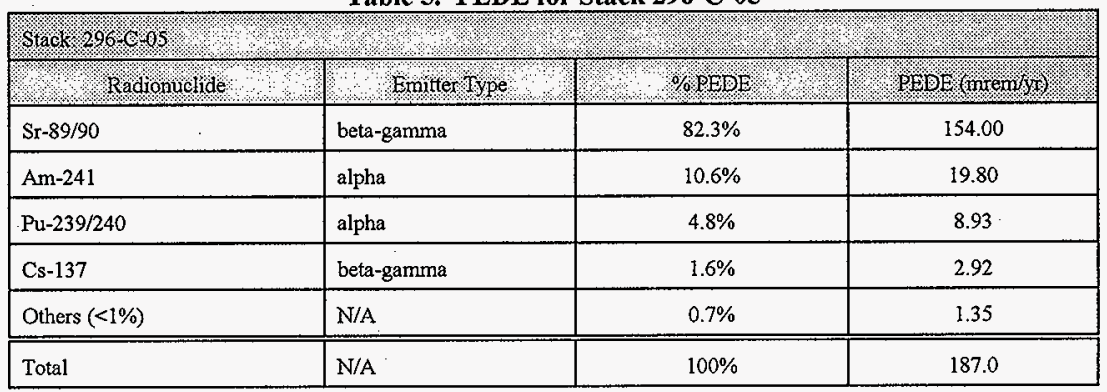

Table 6. PEDE for Stack 296-P-16

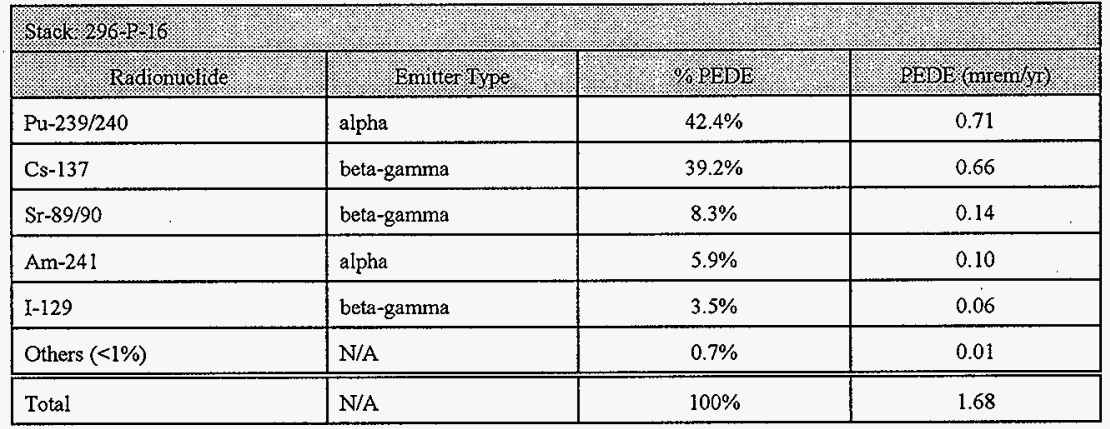

Table 7. PEDE for Stack 296-S-15

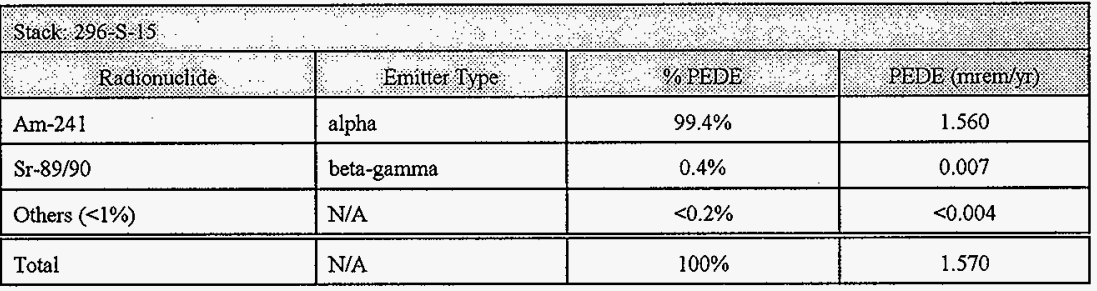


Table 8. PEDE for Stack 296-S-22

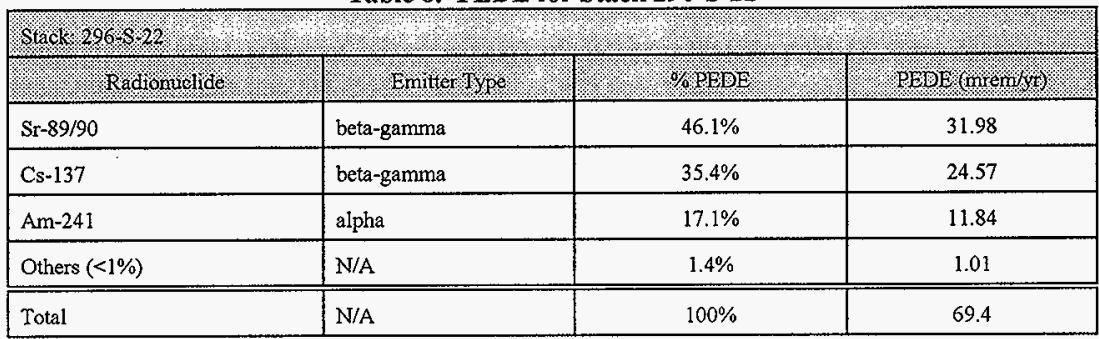

Table 9. PEDE for Stack 296-T-18

\begin{tabular}{|c|c|c|c|}
\hline$(\operatorname{siack} 206-1 / 8,4$ & ४ ২ & +2. & ४े? \\
\hline 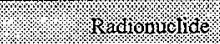 & 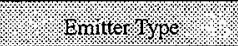 & $\%$ PEPE & 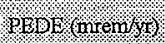 \\
\hline Pu-239/240 & aipha & $55.3 \%$ & 0.21 \\
\hline Cs- 137 & beta-gamma & $23.7 \%$ & 0.09 \\
\hline Am-241 & alpha & $21.0 \%$ & 0.08 \\
\hline Others $(<1 \%)$ & N/A & $<0.01 \%$ & $<0.009$ \\
\hline Total & N/A & $100 \%$ & 0.38 \\
\hline
\end{tabular}

\subsubsection{Particulate Alpha Continuous Monitor}

It is recommended (but not required) that continuous alpha monitors be used on those stacks where $>50$ percent of the PEDE comes from alpha emitting radionuclides. A continuous alpha monitor would prevent a large, predominantly alpha emitter, release from going undetected until the periodic record sample is analyzed. Reviewing Tables 3 through 9, stacks 296-S-15 and 296-T-18 would be recommended for continuous alpha monitors. Stacks $296-$ S-22 and 296-T-18 are presently monitored continuously for particulate alpha activity while the others are not. There are provisions for installation of alpha monitors in the GEMS.

\subsubsection{Sample Flow Instrumentation}

Instrumentation is provided to record and control the record sampler and continuous monitor flow rates, including provisions for totalizing the flow between filter changes. An 
adjustable alarm set point for sample low flow rate is provided. Auxiliary contacts are provided for remote indication, if desired, when sample flow rate deviates beyond required tolerances.

\subsubsection{Data Collection System}

The Data Collection System shall have a standardized communications interface with the existing host computer for the transfer, on command, of recorded values.

The Data Collection System shall record and store stack flow rate, stack temperature, stack relative humidity, record sampler flow rate, total stack flow, and total record sampler flow since the last filter change-out. The beta-gamma monitor shall have its flow rate and readings stored periodically. The data storage shall have a method of data transfer for archival purposes. The transfer media shall be PC compatible.

The Data Collection System shall have a method of transferring data during filter changeout. The record sampler flow readings and total flow, the stack flow readings and total flow, and the date and time of the starting and ending data points shall be the minimum information transferred. The transfer media shall be PC compatible.

\subsubsection{Vacuum System}

A vacuum system is located in the pump cabinet. The system provides a steady, nonpulsing, vacuum source over a range of operating conditions from the maximum and minimum design values of the samplers based on the required collection efficiency. Two vacuum pumps are provided for redundancy.

Each particulate sampling line has its own flow regulation. The vacuum supply to each sample line is adjustable and automatically regulated so that individual sample flow rates are maintained. Components can be isolated individually by isolation valves provided.

The individual vacuum exhaust lines are combined in to a single return manifold. The combined return manifold is connected by field piping to the stack downstream of sampling and velocity probes.

\subsection{Stacks}

An analysis was performed to determine the ability of the existing stacks to accept the required probes. The decision to use an existing stack configuration or to replace or modify a stack is based on the ability to provide satisfactory locations for sample and flow sensing probes. The 
locations for the sample extraction and flow sensing probes have been chosen in accordance with ANSI N13.1, the appropriate 40 CFR 60 Appendix A method, and WHC-SD-EN-TI-288 (Criddle 1994). An existing stack is used when the probe mounting location(s) satisfy the applicable criteria. New stack extensions, modifications to existing stacks, or replacement stacks are specified when the existing probe locations do not satisfy the applicable requirements. Appropriate modifications are described for each stack.

The locations for flow sensing probes were chosen to satisfy the requirements of the appropriate 40 CFR 60 method, Method 1 for stacks greater than 12 inches in diameter, and Method 1A for stacks less than 12 inches in diameter. Following installation in the field, an initial stack flow sensor verification test will be performed in accordance with 40 CFR 52 Appendix E. When practical, flow sensing probes are located in the same plane as the sample probes.

The locations for sample probes were chosen in accordance with the guidance of ANSI N13.1 and the requirements of the appropriate 40 CFR 60 Appendix A method. In general, these locations must not exhibit angular or cyclonic flow and must provide acceptable uniformity of contaminant mixing. Specific performance criteria for sample extraction locations is provided by WHC-SDEN-TI-288 (Criddle 1994).

Testing (shop or field) will be performed to qualify the sample extraction locations according to the performance criteria of WHC-SD-EN-TI-288 (Criddle 1994). The velocity profile at the sample location will be measured in accordance with 40 CFR 60 Appendix A, Method 1, Section 2.4, "Verification of the Absence of Cyclonic Flow." Satisfactory contaminant mixing will be demonstrated in accordance with the methods described in WHC-SD-EN-TI-288 (Criddle 1994), Section 3.3, "Methods for Qualifying the Sample Extraction Location."

An assumption has been made that locating sample probes in accordance with the ANSI N13.1 and 40 CFR 60 Appendix A will result in sample locations that satisfy performance criteria of WHC-SD-EN-TI-288 (Criddle 1994). The validity of this assumption will be demonstrated by shop or field testing. When the existing sample locations are in accordance with ANSI N13.1 and 40 CFR 60 Appendix A, the sample location will be qualified by field testing after performance of any additional stack modifications.

Several of the existing stack designs utilize flow straightening vanes because the stacks have tangential inlets which tend to induce swirling. An assumption has been made that flow straightening vanes will not be required with the new stack extensions. However, removable spool pieces are provided to allow installation of flow vanes if testing indicates unacceptable flow conditions at the sample extraction location.

As mentioned previously, the decision to replace or modify a stack is based on the ability of the 
stack to provide satisfactory probe locations. An assumption has been made that the existing stack heights provide adequate dilution and dispersion. It was not within the scope of Conceptual Design for Project W-420 to verify that existing stacks satisfy requirements for dilution and dispersion of contaminants. Therefore, the original stack height is used as the minimum height for new stack extensions. This should be confirmed early in Definitive Design or in a separate study.

Preliminary calculations indicate that several of the existing stacks have low stack discharge velocity that may result in extensive downwash along the stack. It is recommended that a separate study be performed prior to detailed design of new stack extensions to ensure the stack effluent escapes the air flow patterns surrounding adjacent buildings and provides adequate dilution and dispersion of contaminants to prevent an unacceptable situation when the effluent reaches the ground.

\subsection{Utilities}

Electrical power for the stack monitors will be provided from the same panel boards that supply the existing stack monitors. Existing conduit will be utilized to the maximum extent practical. All electrical materials and equipment shall be UL or FM tested, with labels attached, for the purpose intended, whenever such products are available. Installation methods shall be in accordance with manufacturer's instructions, NFPA 70, and with other applicable requirements. A 30 A, 120 VAC, single phase power supply is required for the stack monitors. The single feed connects with a power distribution panel in the pump cabinet supplied by the stack monitor vendor. Distribution from the pump cabinet to the sample cabinet and the electronics cabinet will be performed through short runs of galvanized rigid steel (or flexible seal tight) conduit.

\subsection{Work Platforms}

Work platforms are provided for routine access to the sample cabinets which are located next to the sample probe location. The work platforms shall have guardrails and toe boards that conform to 29 CFR 1910.23(c), and ladders that conform to 29 CFR 1910.27. Conceptual Design allows for a 60 degree pitch for the ladders. A safety chain will be provided at the access to the platform. 


\subsection{Detailed Installation Descriptions (By Facility)}

\subsubsection{Stack 296-T-18 (244-TX)}

- $\quad$ Stack

The existing sample and velocity probe locations for Stack 296-T-18 do not satisfy the criteria of 40 CFR 60 Appendix A Method 1A. Therefore, the existing 6-inch $(15 \mathrm{~cm})$ diameter, 11 foot $(3.4 \mathrm{~m})$ long stack and air straightening vane/pitot tube assembly (Air Monitor Fan-E) will be removed and replaced with a new stack. It is possible to only remove a portion of the stack and install a new extension, but this option would preclude conducting qualification testing in the shop, which is highly desirable over field testing from a cost perspective.

The discharge velocity for this stack with a nominal flow rate of $125 \mathrm{cfm}$ $\left(5.9 \times 10^{-2} \mathrm{~m}^{3} / \mathrm{s}\right)$ to $250 \mathrm{cfm}\left(1.2 \times 10^{-1} \mathrm{~m}^{3} / \mathrm{s}\right)$ is approximately $637 \mathrm{fpm}(3.2 \mathrm{~m} / \mathrm{s})$ to $1,273 \mathrm{fpm}(6.5 \mathrm{~m} / \mathrm{s})$. Discharge velocities in this range may cause extensive downwash which reduces the effective stack height. The new stack will, therefore, be 4 inches $(10 \mathrm{~cm})$ in diameter instead of 6 inches $(15 \mathrm{~cm})$ to increase discharge velocity and minimize the potential for downwash along the stack. A 4-inch (10 $\mathrm{cm})$ diameter increases velocity to approximately $1,436 \mathrm{fpm}(7.3 \mathrm{~m} / \mathrm{s})$ to $2,873 \mathrm{fpm}$ $(15 \mathrm{~m} / \mathrm{s})$, resulting in a stack to wind velocity ratio of .8 to 1.6 . A ratio of 1.5 is recommended to keep stack downwash to a minimum (ASHRAE Fundamentals Handbook).

The new stack will be constructed of 4 inch $(10 \mathrm{~cm})$ carbon steel pipe with the sample probe located at the 6.42 feet $(2 \mathrm{~m})$ height, and the velocity probe located at the 9.08 feet $(2.8 \mathrm{~m})$ height. Total stack height will be 11 feet $(3.4 \mathrm{~m})$. The new stack includes a spool piece section to allow installation of a flow straightening vane if necessary, a 3 inch $(7.6 \mathrm{~cm})$ flange connection for the sample probe at the 6.42 feet $(2 \mathrm{~m})$ height, a 1 inch $(2.5 \mathrm{~cm})$ sample return connection located 15 inches $(38 \mathrm{~cm})$ from the top of the stack, and 1 -inch $(2.5 \mathrm{~cm})$ connections for mounting temperature, humidity, and velocity probes at the 9.08 feet $(2.8 \mathrm{~m})$ height. Two, 1 inch $(2.5 \mathrm{~cm})$ calibration ports will also be installed below the sample probe location and below the velocity probe location. 


\section{- Concrete}

New equipment pads will be provided for the electronics and pump cabinets and for the work platform that will be installed. The cabinet pad will be approximately 6.5 feet $(2 \mathrm{~m})$ by 3.5 feet $(1.1 \mathrm{~m}), 6$ inches $(15 \mathrm{~cm})$ thick, and located 3 feet $(0.9$ $\mathrm{m}$ ) off the west side of the existing instrumentation building. The skid containing the electronics cabinet and pump cabinet will be mounted to this new pad with ten concrete anchors $[5 / 8$ inch $(1.6 \mathrm{~cm})$ diameter bolts]. The second pad will be approximately 7 feet $(2.1 \mathrm{~m})$ by 3 feet $(0.9 \mathrm{~m})$ and will be located immediately to the west of the existing ventilation equipment pad. Two legs and the ladder of the work platform will be anchored to the new pad and the other two legs will be anchored to the existing pad. Refer to Sketches W420-244TX-SK1 and -SK2.

\section{- Excavation}

Excavation will be required for placement of new equipment support pads. There will be no excavation work for electrical and instrumentation conduits. Existing conduit and trenches will be used.

\section{- Utilities}

Power will be supplied from Panel Board DP-TX-001 located in the motor control center in the instrument building. The existing 15A single-pole breaker in circuit 18 will be replaced with a $30 \mathrm{~A}$ single-pole breaker to provide power to the cabinet. Circuits 20, 22, and 24 in the Panel Board will become spares. The conductor used will be 3 conductor, 10 AWG, THHN, or THWN copper wire. The wire will be run in new $3 / 4$ inch $(1.9 \mathrm{~cm})$ galvanized rigid steel conduit run along the outside of the instrument building to the stack monitor pump cabinet. Refer to Sketch W420-244TX-SK3.

- Work Platform

A work platform approximately 3 feet. $(0.9 \mathrm{~m})$ high, will be installed to allow for routine access to the sampler cabinet. The platform dimensions are to be approximately 4.17 feet $(1.3 \mathrm{~m})$ by 3.33 feet $(1 \mathrm{~m})$ and will be constructed of square tubular steel, angle iron, metal deck grating, and a pitched ladder with handrails. Steel safety rails with a safety chain will be provided.

- Modifications to Existing Equipment 
Installation of the new air sampling and monitoring system will require modification of alarms, indications, and interlocks associated with the existing air monitoring system. Alarms, indicators, and recorders will be disconnected, removed, and/or relabeled. Alarms and indications to the Computer Automated Surveillance System (CASS) will be disconnected and the CASS reconfigured. Contacts for exhaust fan shutdown interlocks will be disconnected and jumpered. Alarms, indications, and interlocks associated with Stack 296-T-18 (244-TX) are identified by Table 10 .

Alarms and indications for the new air sampling and monitoring systems will be provided locally on the instrument cabinets. Auxiliary contacts are provided for remote indication, if desired, when sample flow rate deviates beyond required tolerances and for two remote indications--one for high radiation and one for CAM failure.

\section{- Disposal of Equipment/Material}

Installation of the new monitoring system and stack extension will require removal and disposal of the following equipment and material:

- the exhaust unit enclosure assembly,

- $\quad 12$ feet $(3.7 \mathrm{~m})$ of $1 / 2$ inch $(1.3 \mathrm{~cm})$ sample piping,

- $\quad 12$ feet $(3.7 \mathrm{~m})$ of 1 inch $(2.5 \mathrm{~cm})$ sample return piping,

- $\quad 11$ feet $(1.2 \mathrm{~m})$ section of 6-inch $(15 \mathrm{~cm})$ diameter exhaust stack, an air straightening vane/pitot tube assembly (Air Monitor Fan-E), and

- three isokinetic sample probes/flange assemblies.

The stack, sample probes, sample transport piping, and portions of the exhaust unit enclosures have the potential for low levels of radioactive contamination. This material will be appropriately packaged and shipped to the Low-Level Disposal Site for burial.

Excavation for the new equipment pad will require disposal of approximately $27 \mathrm{ft}^{3}$ $\left(0.8 \mathrm{~m}^{3}\right)$ of potentially contaminated dirt. 
Table 10. Stack 296-T-18 Remote Alarms, Indications, and Interlocks (Existing)

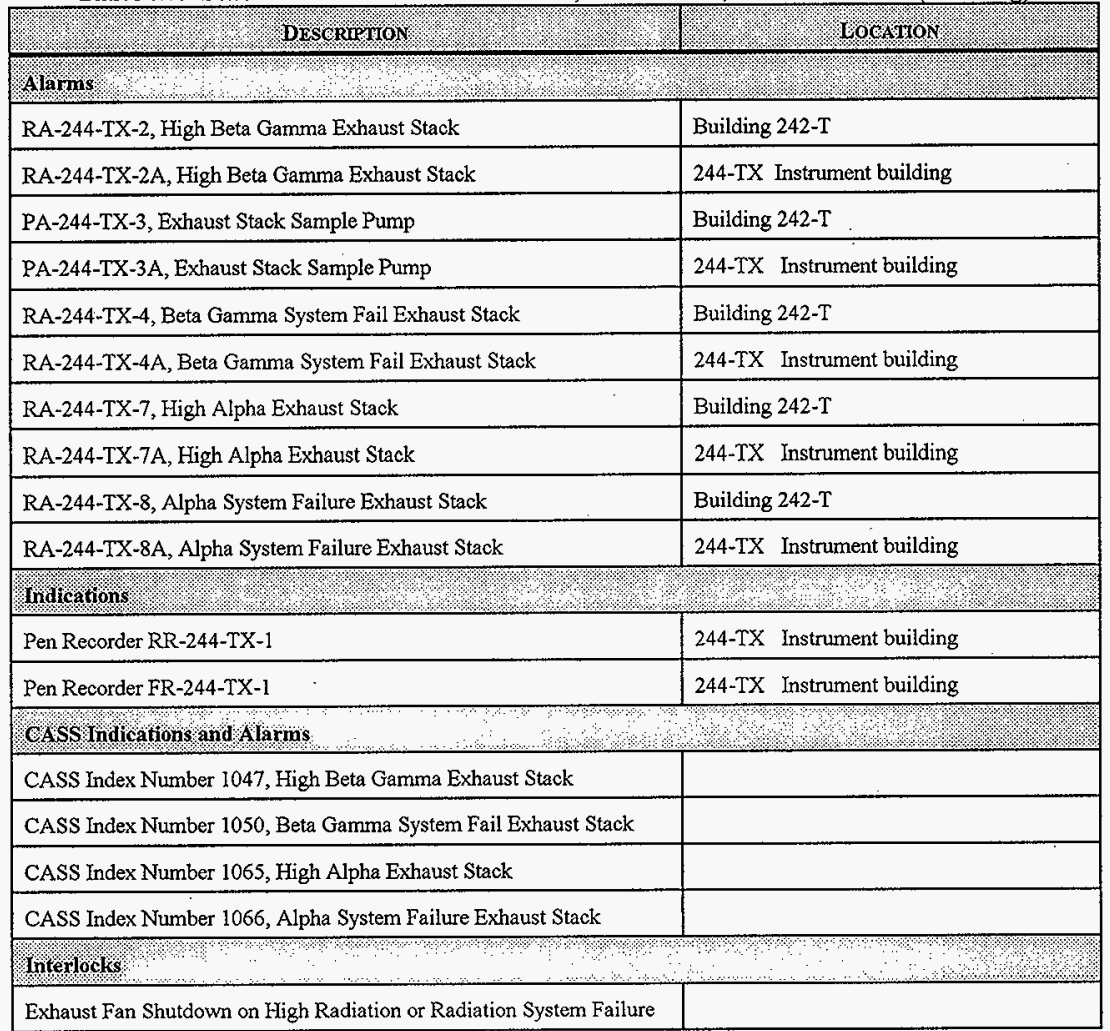

\subsubsection{Stack 296-B-28 (244-BX)}

- Stack

The existing sample and velocity probe locations for Stack 296-B-28 do not satisfy the criteria of 40 CFR 60 Appendix A, Method 1A. Therefore, the existing 6-inch 
$(15 \mathrm{~cm})$ diameter, 11 foot $(3.4 \mathrm{~m})$ long stack and air straightening vane/pitot tube assembly (Air Monitor Fan-E) will be removed and replaced with a new stack. It is possible to only remove a portion of the stack and install a new extension, but this option would preclude conducting qualification testing in the shop, which is highly desired over field testing.

The discharge velocity for this stack with a nominal flow rate of $125 \mathrm{cfm}$ $\left(5.9 \times 10^{-2} \mathrm{~m}^{3} / \mathrm{s}\right)$ to $250 \mathrm{cfm}\left(1.2 \times 10^{-1} \mathrm{~m}^{3} / \mathrm{s}\right)$ is approximately $637 \mathrm{fpm}(3.2 \mathrm{~m} / \mathrm{s})$ to $1,273 \mathrm{fpm}(6.5 \mathrm{~m} / \mathrm{s})$. Discharge velocities in this range may cause extensive downwash which reduces the effective stack height. The new stack will, therefore, be 4 inches $(10 \mathrm{~cm})$ in diameter instead of 6 inches $(15 \mathrm{~cm})$ to increase discharge velocity and minimize the potential for downwash along the stack. A 4-inch (10 $\mathrm{cm})$ diameter increases velocity to approximately $1,436 \mathrm{fpm}(7.3 \mathrm{~m} / \mathrm{s})$ to $2,873 \mathrm{fpm}$ $(15 \mathrm{~m} / \mathrm{s})$, resulting in a stack to wind velocity ratio of .8 to 1.6 . A ratio of 1.5 is recommended to keep stack downwash to a minimum (ASHRAE Fundamentals Handbook).

The new stack will be constructed of 4 inch $(10 \mathrm{~cm})$ carbon steel pipe with the sample probe located at the 6.42 feet $(2 \mathrm{~m})$ height, and the velocity probe located at the 9.08 feet $(2.8 \mathrm{~m})$ height. Total stack height will be 11 feet $(3.4 \mathrm{~m})$. The new stack includes a spool piece section to allow installation of a flow straightening vane if necessary, a 3 inch $(7.6 \mathrm{~cm})$ flange connection for the sample probe at the 6.42 feet $(2 \mathrm{~m})$ height, a 1 inch $(2.5 \mathrm{~cm})$ sample return connection located 15 inches $(38 \mathrm{~cm})$ from the top of the stack, and 1 -inch $(2.5 \mathrm{~cm})$ connections for mounting temperature, humidity, and velocity probes at the 9.08 feet $(2.8 \mathrm{~m})$ height. Two, 1 inch $(2.5 \mathrm{~cm})$ calibration ports will also be installed below the sample probe location and below the velocity probe location.

\section{- Concrete}

New equipment pads will be provided for the electronics and pump cabinets and for the work platform that will be installed. The cabinet pad will be approximately 6.5 feet $(2 \mathrm{~m})$ by 3.5 feet $(1.1 \mathrm{~m}), 6$ inches $(15 \mathrm{~cm})$ thick, and located 3 feet $(0.9$ $\mathrm{m})$ off the north side of the existing instrumentation building. The skid containing the electronics cabinet and pump cabinet will be mounted to this new pad with ten concrete anchors [ $5 / 8$ inch $(1.6 \mathrm{~cm})$ diameter bolts]. The second pad will be approximately 7 feet $(2.1 \mathrm{~m})$ by 3 feet $(0.9 \mathrm{~m})$ and will be located immediately to the north of the existing ventilation equipment pad. Two legs and the ladder of the work platform will be anchored to the new pad and the other two legs will be anchored to the existing pad. 


\section{- Excavation}

Excavation will be required for placement of new equipment support pads. There will be no excavation work for electrical and instrumentation conduits. Existing conduit and trenches will be used.

\section{- Utilities}

Power will be supplied from Panel Board DP-BX-001 located in the motor control center in the instrument building. The existing $15 \mathrm{~A}$ single pole breaker in circuit 18 will be replaced with a $30 \mathrm{~A}$ single pole breaker to provide power to the cabinet. Circuits 15,17, 20, and 24 in the Panel Board will become spares. The conductor used will be 3 conductor, $10 \mathrm{AWG}$, THHN, or THWN copper wire. The wire will be run in new $3 / 4$ inch $(1.9 \mathrm{~cm})$ galvanized rigid steel conduit run along the outside of the instrument building to the stack monitor pump cabinet.

\section{- Work Platform}

A work platform approximately 3 feet $(0.9 \mathrm{~m})$ high will be installed to allow for routine access to the sampler cabinet. The platform dimensions are to be approximately 4.17 feet $(1.3 \mathrm{~m})$ by 3.33 feet $(1 \mathrm{~m})$ and will be constructed of square tubular steel, angle iron, metal deck grating, and a ladder with handrails Steel safety rails with a safety chain will be provided.

\section{- Modifications to Existing Equipment}

Alarms, indications, and interlocks associated with the existing GEMS will be replaced with alarms and indications provided locally on the new instrument cabinets. The alarms, indicators, and recorders that will be disconnected, removed, and/or relabeled are similar to those identified for Stack 296-T-18 (Table $10)$.

\section{- Disposal of Equipment/Material}

Installation of the new monitoring system and stack extension will require removal and disposal of the following equipment and material:

- the exhaust unit enclosure assembly,

- 8 feet $(2.4 \mathrm{~m})$ of $1 \frac{1}{2}$ inch $(1.3 \mathrm{~cm})$ sample piping, 
- $\quad 12$ feet $(3.7 \mathrm{~m})$ of 1 inch $(2.5 \mathrm{~cm})$ sample return piping,

- $\quad 11$ feet $(1.2 \mathrm{~m})$ section of 6-inch $(15 \mathrm{~cm})$ diameter exhaust stack,

- $\quad$ an air straightening vane/pitot tube assembly (Air Monitor Fan-E), and

- two isokinetic sample probes/flange assemblies.

The stack section, sample probes, sample transport piping, and portions of the exhaust unit enclosures have the potential for low levels of radioactive contamination. Excavation for the new equipment pad will require disposal of approximately $27 \mathrm{ft}^{3}\left(0.8 \mathrm{~m}^{3}\right)$ of potentially contaminated dirt. This material will be appropriately packaged and sent to the Low-Level Waste Disposal Site for burial.

\subsubsection{Stack 296-S-22 (244-S)}

\section{- $\quad$ Stack}

The existing sample and velocity probe locations for Stack 296-S-22 do not satisfy the criteria of 40 CFR 60, Appendix A, Method 1A. Therefore, the existing 6-inch $(15 \mathrm{~cm})$ diameter, 11 foot $(3.4 \mathrm{~m})$ long stack and air straightening vane/pitot tube assembly (Air Monitor Fan-E) will be removed and replaced with a new stack. It is possible to only remove a portion of the stack and install a new extension, but this option would preclude conducting qualification testing in the shop, which is highly desired over field testing.

The discharge velocity for this stack with a nominal flow rate of $125 \mathrm{cfm}$ $\left(5.9 \times 10^{-2} \mathrm{~m}^{3} / \mathrm{s}\right)$ to $250 \mathrm{cfm}\left(1.2 \times 10^{-1} \mathrm{~m}^{3} / \mathrm{s}\right)$ is approximately $637 \mathrm{fpm}(3.2 \mathrm{~m} / \mathrm{s})$ to $1,273 \mathrm{fpm}(6.5 \mathrm{~m} / \mathrm{s})$. Discharge velocities in this range may cause extensive downwash which reduces the effective stack height. The new stack will, therefore, be 4 inches $(10 \mathrm{~cm})$ in diameter instead of 6 inches $(15 \mathrm{~cm})$ to increase discharge velocity and minimize the potential for downwash along the stack. A 4-inch (10 $\mathrm{cm})$ diameter increases velocity to approximately $1,436 \mathrm{fpm}(7.3 \mathrm{~m} / \mathrm{s})$ to $2,873 \mathrm{fpm}$ $(15 \mathrm{~m} / \mathrm{s})$, resulting in a stack to wind velocity ratio of .8 to 1.6 . A ratio of 1.5 is recommended to keep stack downwash to a minimum (ASHRAE Fundamentals Handbook).

The new stack will be constructed of 4 inch $(10 \mathrm{~cm})$ carbon steel pipe with the sample probe located at the 6.42 feet $(2 \mathrm{~m})$ height, and the velocity probe located at the 9.08 feet $(2.8 \mathrm{~m})$ height. Total stack height will be 11 feet $(3.4 \mathrm{~m})$. The new stack includes a spool piece section to allow installation of a flow straightening vane if necessary, a 3 inch $(7.6 \mathrm{~cm})$ flange connection for the sample 
probe at the 6.42 feet $(2 \mathrm{~m})$ height, a 1 inch $(2.5 \mathrm{~cm})$ sample return connection located 15 inches $(38 \mathrm{~cm})$ from the top of the stack, and 1-inch $(2.5 \mathrm{~cm})$ connections for mounting temperature, humidity, and velocity probes at the 9.08 feet $(2.8 \mathrm{~m})$ height. Two, 1 inch $(2.5 \mathrm{~cm})$ calibration ports will also be installed below the sample probe location and below the velocity probe location.

\section{- Concrete}

One new equipment pad approximately 7 feet $(2.1 \mathrm{~m})$ by 5 feet $(1.5 \mathrm{~m})$ and 6 inches $(15 \mathrm{~cm})$ thick will be located immediately to the west of the existing ventilation equipment pad. Two legs and the ladder of the work platform will be anchored to the new pad and the other two legs will be anchored to the existing pad. The skid containing the electronics cabinet and pump cabinet will be mounted to the existing ventilation equipment pad with ten concrete anchors $[5 / 8$ inch (1.6 $\mathrm{cm})$ diameter bolts].

\section{- Excavation}

Excavation will be required for placement of the new equipment support pad. There will be no excavation work for electrical and instrumentation conduits. Existing conduit and trenches will be used.

\section{- Utilities}

Power will be supplied from Panel Board "B" located in the motor control center in the instrument building. The existing 15A single-pole breaker in circuit 17 will be replaced with a $30 \mathrm{~A}$ single-pole breaker to provide power to the cabinet. Circuits 18,19, and 20 in the Panel Board will become spares. The conductor used will be 3 conductor, $10 \mathrm{AWG}$, THHN, or THWN copper wire. The wire will be run in existing conduit P-20 to the extent possible, and in new $3 / 4$ inch $(1.9 \mathrm{~cm})$ galvanized rigid steel conduit run along the outside of the instrument building to the stack monitor pump cabinet. 


\section{- Work Platform}

A work platform approximately 3 -feet $(0.9 \mathrm{~m})$ high will be installed to allow for routine access to the sampler cabinet. The platform dimensions are to be approximately 4.17 feet $(1.3 \mathrm{~m})$ by 3.33 feet $(1 \mathrm{~m})$ and will be constructed of square tubular steel, angle iron, metal deck grating, and a ladder with handrails. Steel safety rails with a safety chain will be provided.

- Modifications to Existing Equipment

Alarms, indications, and interlocks associated with the existing GEMS will be replaced with alarms and indications provided locally on the new instrument cabinets. The alarms, indicators, and recorders that will be disconnected, removed, and/or relabeled are similar to those identified for Stack 296-T-18 (Table 10)

\section{- Disposal of Equipment/Material}

Installation of the new monitoring system and stack extension will require removal and disposal of the following equipment:

- $\quad$ the exhaust unit enclosure assembly,

- $\quad 12$ feet $(3.7 \mathrm{~m})^{\prime}$ of $1 / 2$ inch $(1.3 \mathrm{~cm})$ sample piping,

- $\quad 12$ feet $(3.7 \mathrm{~m})$ of 1 inch $(2.5 \mathrm{~cm})$ sample return piping,

- $\quad 11$ foot $(1.2 \mathrm{~m})$ section of 6-inch $(15 \mathrm{~cm})$ diameter exhaust stack,

- $\quad$ an air straightening vane/pitot tube assembly (Air Monitor Fan-E), and

- $\quad$ three isokinetic sample probes/flange assemblies.

The stack section, sample probes, sample transport piping, and portions of the exhaust unit enclosures have the potential for low levels of radioactive contamination. Excavation for the new equipment pad will require disposal of approximately $27 \mathrm{ft}^{3}\left(0.8 \mathrm{~m}^{3}\right)$ of potentially contaminated dirt. This material will be appropriately packaged and sent to the Low-Level Waste Disposal Site for burial. 


\subsubsection{Stack 296-S-15 (241-SX)}

\section{- $\quad$ Stack}

The existing Stack 296-S-15 will be removed and replaced because the sample and velocity probe locations do not satisfy the criteria of 40 CFR 60 Appendix A, Method 1. The existing 42-inch $(107 \mathrm{~cm})$ diameter, 15 -foot $(4.6 \mathrm{~m})$ stack is replaced with a 20 -inch $(51 \mathrm{~cm})$ diameter, 20 -foot $(6.1 \mathrm{~m})$ stack. The original stack was designed for a flow rate of $22,650 \mathrm{cfm}\left(10.7 \mathrm{~m}^{3} / \mathrm{s}\right)$ which is greater than the present design flow rate of $6,100 \mathrm{cfm}\left(2.9 \mathrm{~m}^{3} / \mathrm{s}\right)$. The existing stack size and flow rate provide a stack velocity of approximately $634 \mathrm{fpm}(3.2 \mathrm{~m} / \mathrm{s})$ and a stack to wind velocity ratio of 0.36 [wind velocity $20 \mathrm{mph}$ or $1,760 \mathrm{fpm}(8.9 \mathrm{~m} / \mathrm{s})$ ] which is inadequate to prevent extensive stack downwash. The new stack diameter of 20 inches $(51 \mathrm{~cm})$ increases discharge velocity to $2,800 \mathrm{fpm}(14 \mathrm{~m} / \mathrm{s})$ and the stack to wind velocity ratio to 1.6. A ratio of 1.5 is recommended to keep stack downwash to a minimum (ASHRAE Fundamentals Handbook).

Replacement of the existing stack will require replacement of the existing ventilation ducting from the expansion joint on the discharges of both fans. The sample probe inlet and velocity probe will be located at the 17 foot $(5.2 \mathrm{~m})$ height which was chosen to satisfy 40 CFR 60 Appendix A, Method 1 criteria. The new stack includes separate flanges for mounting the sample and velocity probes and a spool piece section to allow installation of a flow straightening vane if necessary. At the 18 foot $(5.5 \mathrm{~m})$ height, 1-inch $(2.5 \mathrm{~cm})$ connections for mounting temperature, humidity, and return lines are located. Two, 1 inch $(2.5 \mathrm{~cm})$ calibration ports will also be installed below the sample/velocity probe location. Note that the actual location of the sample probe flange will depend on the final probe design which positions the probe inlet somewhere below the flange.

\section{- Concrete}

A new equipment pad will be provided for the electronics and pump cabinets. The pad will be approximately 15 feet $(4.6 \mathrm{~m})$ by 5 feet $(1.5 \mathrm{~m}), 6$ inches thick, and located directly east of the ventilation equipment pad. The existing stack monitor pad will be removed. The skid containing the electronics cabinet and pump cabinet will be mounted to this new pad with ten concrete anchors $[5 / 8$ inch $(1.6 \mathrm{~cm})$ diameter bolts]. Two legs of the work platform will be anchored to the new pad and the other two legs will be anchored to the existing pad. The ladder will be anchored to a small concrete footing. 


\section{- Excavation}

Excavation will be required for placement of new equipment support pads. There will be no excavation work for electrical and instrumentation conduits. Existing conduit and trenches will be used.

\section{- Utilities}

Power will be supplied from Panel Board "B" located in the 271-SX instrument building. The existing 30A double pole breaker in circuits 6 and 8 will be replaced with a $30 \mathrm{~A}$ single pole breaker in circuit 6 to provide power to the cabinet. Circuit 8 in the Panel Board will become a spare. The conductor used will be 3 conductor, $10 \mathrm{AWG}, \mathrm{THHN}$, or THWN copper wire. The wire will be run in to the extent practical in existing conduit run P-1 from the Panel Board to the stack monitor. New above ground galvanized rigid steel conduit will be installed for the short run from the termination of the existing conduit to the pump cabinet.

\section{- Work Platform}

A work platform approximately 12.67 feet $(3.9 \mathrm{~m})$ high will be installed to allow for routine access to the sampler cabinet. The platform dimensions are to be approximately $4.17(1.3 \mathrm{~m})$ by 4.83 feet $(1.5 \mathrm{~m})$ and will be constructed of square tubular steel, angle iron, metal deck grating, and a ladder with handrails. Steel safety rails with a safety chain will be provided.

\section{- Modifications to Existing Equipment}

Alarms, indications, and interlocks associated with the existing GEMS will be replaced with alarms and indications provided locally on the new instrument cabinets. The alarms, indicators, and recorders that will be disconnected, removed, and/or relabeled are similar to those identified for Stack 296-T-18 (Table $10)$.

\section{- Disposal of Equipment/Material}

Installation of the new monitoring system and stack will require removal and disposal of the following equipment and material:

- the exhaust unit enclosure assembly, 
- $\quad 5$ feet $(1.5 \mathrm{~m})$ of $3 / 4$ inch $(1.9 \mathrm{~cm})$ sample piping,

- $\quad 5$ feet $(1.5 \mathrm{~m})$ of $1 / 4$ inch $(0.6 \mathrm{~cm})$ sample return piping,

- $\quad 15$ feet $(4.6 \mathrm{~m})$ of 42 -inch $(107 \mathrm{~cm})$ diameter exhaust stack,

- a small portion of the exhaust duct, and

- $\quad$ one isokinetic sample probe/flange assembly.

The stack, sample probes, sample transport piping, and portions of the exhaust unit enclosures have the potential for low levels of radioactive contamination. Removal of the existing stack monitor pad and excavation for the new pad will require disposal of approximately $42 \mathrm{ft}^{3}\left(1.2 \mathrm{~m}^{3}\right)$ of potentially contaminated dirt and concrete. This material will be appropriately packaged and sent to the Low-Level Waste Disposal Site for burial.

\subsubsection{Stack 296-C-05 (244-CR)}

- $\quad$ Stack

The location of the existing stack monitor probe assembly in Stack 296-C-05 satisfies the criteria of 40 CFR 60 , Appendix A, Method 1 for sampling and velocity measurement location. Therefore, the new monitoring system will utilize the existing stack and probe mounting flange. The velocity probe will utilize the existing flange while a new flange is provided to locate the sampler probe inlet in the same plane as the velocity probe. The centerline of the velocity probe flange is located at a height of 17 feet $(5.2 \mathrm{~m})$ in an 18-inch $(46 \mathrm{~cm})$ diameter stack which provides greater than 7 duct diameters downstream from nearest flow disturbance (stack inlet). Note that the actual location of the sample probe flange will depend on the final probe design which positions the probe inlet somewhere below the flange.

The existing pitot tube and flow switch located on the stack at a height of 6 feet $(1.8 \mathrm{~m})$ will be removed and the hole plugged. Modifications to the stack will be made to provide calibration ports and a connection for the sample return line.

\section{- Concrete}

A new equipment pad will be provided for the electronics and pump cabinets. The pad will be approximately 8 feet $(2.4 \mathrm{~m})$ by 12 feet $(3.6 \mathrm{~m}), 6$ inches $(15 \mathrm{~cm})$ thick, and located directly adjacent to the existing stack. The existing stack monitor pad will be removed. The skid containing the electronics cabinet and pump cabinet will be mounted to this new pad with ten concrete anchors $[5 / 8$ inch $1.6 \mathrm{~cm}$ ) diameter 
bolts]. All four legs of the work platform will be anchored to the new equipment $\mathrm{pad}$, and a small concrete footing will be installed to anchor the platform ladder.

\section{- Excavation}

Excavation will be required for placement of new equipment support pads. There will be no excavation work for electrical and instrumentation conduits. Existing conduit and trenches will be used.

\section{- Utilities}

Power will be supplied from Lighting Panel "LA" located in the 271-CR instrument building. The existing $15 \mathrm{~A}$ double-pole breaker in circuits 11 and 13 will be replaced with a $30 \mathrm{~A}$ single-pole breaker in circuit 11 to provide power to the cabinet. Circuit 13 in the Panel Board will become a spare. The conductor used will be 3 conductor, $10 \mathrm{AWG}$, THHN, or THWN copper wire. The wire will be run in existing conduit run P-1 from the Panel Board to the stack monitor pump cabinet.

\section{- Work Platform}

A work platform approximately 12.67 feet $(3.9 \mathrm{~m})$ high will be installed to allow for routine access to the sampler cabinet. The platform dimensions are to be approximately 4.17 feet $(1.3 \mathrm{~m})$ by 4.83 feet $(1.5 \mathrm{~m})$ and will be constructed of square tubular steel, angle iron, metal deck grating, and a ladder with handrails. Steel safety rails with a safety chain will be provided.

\section{- Modifications to Existing Equipment}

Alarms, indications, and interlocks associated with the existing GEMS will be replaced with alarms and indications provided locally on the new instrument cabinets. The alarms, indicators, and recorders that will be disconnected, removed, and/or relabeled are similar to those identified for Stack 296-T-18 (Table $10)$. 


\section{- Disposal of Equipment/Material}

Installation of the new monitoring system will require removal and disposal of the following equipment and materials:

- the exhaust unit enclosure assembly,

- $\quad 24$ feet $(7.3 \mathrm{~m})$ of $3 / 4$ inch $(1.9 \mathrm{~cm})$ sample piping,

- 6 feet $(1.8 \mathrm{~m})$ of steel pipe support, an airflow switch,

- 6 feet $(1.8 \mathrm{~m})$ of $1 / 2$ inch $(1.3 \mathrm{~cm})$ flex conduit with 14 AWG wire, and

- $\quad$ one isokinetic sample probe/flange assembly.

The sample probe, sample transport piping, and portions of the exhaust unit enclosures have the potential for low levels of radioactive contamination. Removal of the existing stack monitor pad and excavation for the new pad will require disposal of approximately $42 \mathrm{ft}^{3}\left(1.2 \mathrm{~m}^{3}\right)$ of potentially contaminated dirt and concrete. This material will be appropriately packaged and sent to the Low-Level Waste Disposal Site for burial.

\subsubsection{Stack 296-P-16 (241-C-104/105/106)}

\section{- $\quad$ Stack}

The location of the existing stack monitor probe assembly in Stack 296-P-16 satisfies the criteria of 40 CFR 60 , Appendix A, Method 1 for sampling and velocity measurement location. However, the stack is small enough that it would be most cost effective to replace the stack entirely rather than to try and add additional instrument ports in the field. The centerline of the sample probe flange is located at a height of approximately 7 feet $(2.1 \mathrm{~m})$ in a 16-inch $(41 \mathrm{~cm})$ stack which is 5.25 duct diameters downstream from the nearest flow disturbance (stack inlet) and 2.25 diameters upstream from the nearest flow disturbance (stack outlet). Design changes to the stack will be made to provide calibration ports and a connection for the sample return line. The existing stack is fabricated from 11 gauge carbon steel sheet metal which will be used for the replacement stack. Note that the actual location of the sample probe flange will depend on the final probe design which positions the probe inlet somewhere below the flange. 


\section{- Concrete}

A new concrete pad will be provided for the electronics and pump cabinets skid. The pad will be approximately 6.5 feet $(2 \mathrm{~m})$ by $3.5(1.1 \mathrm{~m})$ feet and located directly adjacent to the existing exhaust unit.

\section{- Excavation}

Excavation will be required for placement of new equipment support pads. There will be no excavation work for electrical and instrumentation conduits. Existing conduit and trenches will be used.

\section{- Utilities}

Power will be supplied from the existing stack monitor disconnect switch on the exhauster skid. The existing 20A fuses will be replaced with a 30A fuses, or the disconnect switch will be replaced if needed (pending field verification of model and availability of fuses). Line AS- 1 and the neutral line AS-N will be run to the stack monitor, while line AS-2 will be removed. Lines HT-1 and HT-N for exhauster heat trace will remain the same. The conductor used will be 3 conductor, $10 \mathrm{AWG}$, THHN, or THWN copper wire. New above ground galvanized rigid steel conduit will be installed for the short run from the existing disconnect switch to the pump cabinet.

\section{- Work Platform}

A work platform approximately 6.17 feet $(1.9 \mathrm{~m})$ high will be installed to allow for routine access to the sampler cabinet. The platform dimensions are to be approximately 4.17 feet $(1.3 \mathrm{~m})$ by 4.83 feet $(1.5 \mathrm{~m})$ and will be constructed of square tubular steel, angle iron, metal deck grating, and a ladder with handrails. Steel safety rails with a safety chain will be provided. The platform will be mounted with the front two legs on the mobile exhauster skid, the back two legs on the existing concrete pad, and a small concrete footing off the existing pad for anchoring the ladder.

\section{- Modifications to Existing Equipment}

Alarms, indications, and interlocks associated with the existing GEMS will be replaced with alarms and indications provided locally on the new instrument 
cabinets. The alarms, indicators, and recorders that will be disconnected, removed, and/or relabeled are similar to those identified for Stack 296-T-18 (Table $10)$.

\section{- Disposal of Equipment/Material}

Installation of the new monitoring system will require removal and disposal of the following equipment:

- the exhaust unit enclosure assembly,

- $\quad 5$ feet $(1.5 \mathrm{~m})$ of $3 / 4$ inch $(1.9 \mathrm{~cm})$ sample piping,

- $\quad 5$ feet $(1.5 \mathrm{~m})$ of $1 / 4$ inch $(.64 \mathrm{~cm})$ sample piping,

- $\quad 10$ feet $(3 \mathrm{~m})$ of 1 inch $(2.5 \mathrm{~cm})$ sample return piping,

- $\quad$ one isokinetic sample probe/flange assembly, and

- $\quad 10$ feet $(3 \mathrm{~m})$ of $16-$ inch $(41 \mathrm{~cm})$ diameter exhaust stack.

The stack sample probe, sample transport piping, and portions of the exhaust unit enclosures have the potential for low levels of radioactive contamination.

Excavation for the new equipment pad will require disposal of approximately $27 \mathrm{ft}^{3}$ $\left(0.8 \mathrm{~m}^{3}\right)$ of potentially contaminated dirt. This material will be appropriately packaged and sent to the Low-Level Waste Disposal Site for burial.

\subsubsection{Stack 296-A-25 (244-A)}

\section{- $\quad$ Stack}

The existing sample and velocity probe locations for Stack 296-A-25 do not satisfy the criteria of 40 CFR 60 Appendix A, Method 1A. The existing stack is a single piece, 4-inch $(10 \mathrm{~cm})$ diameter, 9.5 foot $(2.9 \mathrm{~m})$ tall construction with a velocity probe at the 5 foot $(1.5 \mathrm{~m})$ level, and a sample probe at the 8 foot $(2.4 \mathrm{~m})$ level.

A new stack will be constructed of 4 inch $(10 \mathrm{~cm})$ carbon steel pipe with the sample probe located at the 6.42 feet $(2 \mathrm{~m})$ height, and the velocity probe located at the 9.08 feet $(2.8 \mathrm{~m})$ height. Total stack height will increase to 11 feet $(3.4 \mathrm{~m})$. The new stack includes a spool piece section to allow installation of a flow straightening vane if necessary, a 3 -inch $(7.6 \mathrm{~cm})$ flange connection for the sample probe at the 6.42 feet $(2 \mathrm{~m})$ height; a 1 inch $(2.5 \mathrm{~cm})$ sample return connection located 15 inches $(38 \mathrm{~cm})$ from the top of the stack, and 1-inch $(2.5 \mathrm{~cm})$ connections for mounting temperature, humidity, and velocity probes at the 9.08 $(2.8 \mathrm{~m})$ height. Two, 1 inch $(2.5 \mathrm{~cm})$ calibration ports will also be installed below 
the sample probe location and below the velocity probe location.

\section{- Concrete}

One new equipment pad approximately 5 feet $(1.5 \mathrm{~m})$ by 12 feet $(3.7 \mathrm{~m}), 6$ inches $(15 \mathrm{~cm})$ thick, will be located adjacent to the existing ventilation equipment pad. Two legs and the ladder of the work platform will be anchored to the new pad and the other two legs will be anchored to the existing pad. The skid containing the electronics cabinet and pump cabinet will be mounted to this new equipment pad with ten concrete anchors $[5 / 8$ inch $(1.6 \mathrm{~cm})$ diameter bolts].

\section{- Excavation}

Excavation will be required for placement of new equipment support pads. There will be no excavation work for electrical and instrumentation conduits. Existing conduit and trenches will be used.

- Utilities

Power will be supplied from Panel Board ' $A$ ' located in the instrument building. The existing 30A two-pole breaker in circuits 17 and 19 will be replaced with a $30 \mathrm{~A}$ single-pole breaker in circuit 17 to provide power to the cabinet. Circuit 19 in the Panel Board will become a spare. The conductor used will be 3 conductor, 10 AWG, THHN, or THWN copper wire. The wire will be run in new $3 / 4$ inch $(1.9 \mathrm{~cm})$ galvanized rigid steel conduit run along the outside of the instrument building to the stack monitor pump cabinet.

- Work Platform

A work platform approximately 3 feet $(0.9 \mathrm{~m})$ high will be installed to allow for routine access to the sampler cabinet. The platform dimensions are to be approximately 4.33 feet $(1.3 \mathrm{~m})$ by 3.33 feet $(1 \mathrm{~m})$ and will be constructed of square tubular steel, angle iron, metal deck grating, and a ladder with handrails. Steel safety rails with a safety chain will be provided. The platform will be mounted on the mobile exhauster skid with a small concrete footing to be added off the skid for anchoring the ladder.

- Modifications to Existing Equipment 
Alarms, indications, and interlocks associated with the existing GEMS will be replaced with alarms and indications provided locally on the new instrument cabinets. The alarms, indicators, and recorders that will be disconnected, removed, and/or relabeled are similar to those identified for Stack 296-T-18 (Table $10)$.

\section{- Disposal of Equipment/Material}

Installation of the new monitoring system and stack will require removal and disposal of the following equipment:

- the exhaust unit enclosure assembly,

- $\quad 12$ feet $(3.7 \mathrm{~m})$ of $1 / 2$ inch $(1.3 \mathrm{~cm})$ sample piping,

- $\quad 12$ feet $(3.7 \mathrm{~m})$ of 1 inch $(2.5 \mathrm{~cm})$ sample return piping,

- $\quad 9.5$ feet $(2.9 \mathrm{~m})$ of 4-inch $(10 \mathrm{~cm})$ diameter exhaust stack, and

- $\quad$ one isokinetic sample probe/flange assemblies.

The stack, sample probe, sample transport piping, and portions of the exhaust unit enclosures have the potential for low levels of radioactive contamination. Removal of the existing stack monitor pad and excavation for the new pad will require disposal of approximately $27 \mathrm{ft}^{3}\left(0.8 \mathrm{~m}^{3}\right)$ of potentially contaminated dirt and concrete.

\subsection{METHODS OF PERFORMANCE}

\subsection{Offsite Architect-Engineer Work}

An offsite Architect-Engineer (A-E) will provide the Definitive Design engineering during construction and may participate in vendor site qualification testing for this project. The offsite A-E will provide assistance during installation, startup, and performance of post-installation testing, including the initial stack flow sensor verification in accordance with 40 CFR 52, Appendix E. 


\subsection{Procurement Strategy}

The operating contractor will prepare the procurement specification for the GEMS and provide procurement services for the entire project. The existing Procurement Specification WHC-S0400 (White 1995), will be modified as necessary and used for procurement of the new systems. This specification was used to procure a monitoring system for Stack 296-A-40. The GEMS vendor will be responsible for design and fabrication of all sampling and monitoring equipment including the sample probes. In some cases the GEMS vendor will provide the new stack or another vendor may be used.

For Stacks 296-A-25, 296-B-28, 296-P-16, 296-S-15, 296-S-22, and 296-T-18 that are to be completely replaced, the offsite A-E will prepare drawings and procurement specifications for the operations contractor to procure the new stacks.

\subsection{Onsite Construction Contractor}

The onsite construction contractor will remove the existing air monitoring systems and stack sections. The onsite construction contractor will perform site installation of the new GEMS, including installation of new stack sections, installation of sampler, electronics, and pump cabinets, field installation of wiring and piping between major subassemblies, field connection of electrical service and signal lines, and installation of maintenance access platforms. Modifications to existing stacks will be performed as required by design media.

\subsection{Work Planned for the Operating Contractor}

The operating contractor will provide overall project management during design, procurement, and construction of the project, will provide safety support, permitting support, procurement services, and operations support during installation. The operating contractor will perform all startup testing including the initial stack flow sensor verification test. Operations support will include such actions as isolating and tagging out existing equipment, new electrical and sampling line tie-ins, Health Physics Technician (HPT) support, Quality Assurance support, etc. Disposal of solid waste will also be supported by the operating contractor.

\subsection{Shutdown of Exhausters}

Each exhauster in this study can be shut down for varying lengths of time for the installation of the new stacks and GEMS. It has been assumed that all the exhausters will be able to be shut down for a sufficient time without the need for installing a temporary ventilation system. Current allowed shutdown conditions are shown below. 


\subsubsection{Stacks 296-A-25, 296-B-28, 296-C-05, 296-S-22, and 296-TX-18}

The ventilation systems on the DCRTs and 244-CR are required to be in operation for either of two conditions per the Operating Specifications for the Saltwell Receiver Vessels, OSD-T-151-00011 (WHC 1994): 1) Waste material surface temperature is $\geq$ 140 degrees $F$, and 2) Transfer waste into the tank is $\geq 140$ degrees $F$. The conditions in the facilities routinely allow shutdown of the ventilation systems for several weeks at a time in the DCRTs.

\subsubsection{Stack 296-S-15}

Stack 296-S-15 is associated with cooling of single-shell tanks (SSTs) in the 241-SX Tank Farm. In accordance with the Operating Safety Document for Single-Shell Tanks, OSDT-151-00013 (WHC 1996a), active ventilation can be shutdown if:

- All tank risers and pits except the exhauster connections are sealed prior to planned shutdown, and

- $\quad$ SST Process Engineering shall determine the maximum time any tank on an active ventilation system can have the ventilation system off the line on a case-by-case basis. During this shutdown time, the passive HEPA breather filters shall be operating.

According to the manager of the tank farm cognizant engineering organization (Kison 1996), the SX Exhauster could be down for several weeks without exceeding a temperature or hydrogen limit. Further studies and process tests have been proposed by this organization to more accurately determine the shutdown time allowed.

\subsubsection{Stack 296-P-16}

The 296-P-16 stack is associated with the cooling of SSTs 104, 105 and 106-C in the 241C Tank Farm. In accordance with the Operating Safety Document for Single-Shell Tanks, OSD-T-151-00013 (WHC 1996a), active ventilation can be shutdown if:

- All tank risers and pits except the exhauster connections are sealed prior to planned shutdown, and

- $\quad$ SST Process Engineering shall determine the maximum time the any tank in an active ventilation system can have the ventilation system off the line on a case-bycase basis. During this shutdown time, the passive HEPA breather filters shall be operating. 
According to the cognizant engineer of the 241-C Tank Farm (Jones 1996), the exhauster could probably be down for several weeks without exceeding a temperature or hydrogen limit. The exhauster was shutdown for a process test on Tank 106-C for approximately one year, but some undesired temperature excursions did occur. Tank 106-C contains the majority of the heat content of the three tanks and is scheduled to have its own exhauster installed for waste retrieval in 1998 under Project W-320. Waste retrieval or installation of a new exhauster for Tank 106-C would allow the 104/105-C exhauster to be shutdown for a longer time period.

\subsection{REQUIREMENTS AND ASSESSMENTS}

\subsection{Safeguards and Security}

Upgrades by Project W-420 will be performed within the security fences of the 200 East and 200 West Areas. Existing safeguards and security measures will not be impacted by this project and new measures beyond current practice are not required.

\subsection{Health and Safety}

Removal of the existing air monitoring systems and stack extensions has the potential to expose workers to low levels of radiation and loose surface contamination. General area radiation levels and loose surface and airborne contamination levels will be determined by the HPT. Appropriate work practices, administrative measures, and controls will be implemented based on the requirements of the Hanford Site Radiological Control Manual (DOE 1993).

Routine construction hazards will exist during performance of this project. Removal and replacement of the stack extensions will require the use of a crane. Hazards may include dropping of a stack extension caused by crane failure, operator error, or rigging failure. In some cases, work will be performed greater than 6 feet $(1.8 \mathrm{~m})$ above the ground. In this case, appropriate fall prevention devices and procedures will be used.

Hazards associated with construction activities will be considered and mitigated to the extent practical. The contractor industrial safety and health program will be used to control industrial work hazards. All reasonable precautions will be taken to protect the safety and health of personnel including regular safety inspections by safety personnel and management. A Job Safety Analysis (JSA) will be prepared to identify all possible hazards and means to mitigate potential accidents. The JSA will be prepared in accordance with WHC-CM-1-10, Safety Manual (WHC 1995a) and Tank Farm Health and Safety Plan (WHCb). All site and contractor health and safety programs will comply with 10 CFR 1910, Occupational Safety and Health, and 10 CFR 
1926, Construction Safety.

\subsection{Decontamination and Decommissioning}

The existing air monitoring systems at each of the seven stacks will be removed and disposed of appropriately. The sample probes, sample transport piping, and portions of the exhaust unit enclosures have the potential for low levels of radioactive contamination. Stack emission records shall be reviewed to determine the level of contamination that may be present. Portions of the system, such as the cabinets, are not likely to be contaminated and may be able to be disposed of as normal industrial waste.

The project will provide for temporary storage, packaging, transportation, and disposal of solid low-level waste. It is expected that minimal decontamination will be required. The specific equipment and material that will be removed for disposal from each location is identified in Section 3.5 .

\subsection{Maintenance and Operation Requirements}

The sampler cabinet will be accessed on a routine basis for change out of record sampler filter papers. Filter paper change out will occur either on a monthly or every two weeks schedule. Typical time to change out the filter, download data, and perform routine checks will be approximately one hour.

The sample probe will be accessed on a recommended six-month schedule for inspection per WHC-SD-WM-TI-288 (Criddle 1994). However, the Conceptual Design Report (CDR) authors believe this recommendation can be relaxed once some experience is gained with the system. The non-erosive and non-corrosive nature of the stack offgasses will cause minimal, if any, degradation of the sampling probe.

The air monitoring and sampling systems will be designed to provide adequate space for removal and replácement of individual instruments and equipment. Components will be selected and installed to minimize the maintenance effort. System design will allow adjustments, maintenance, calibration, and testing to be performed to the greatest extent possible with standard tools and test equipment.

The vendor will identify the necessary standard tools and test equipment and provide any required special tools unique to the vendor's equipment. The vendor will also provide a description of recommended spare parts and instructions for operation, calibration, and maintenance of the new systems. 


\subsection{Automatic Data Processing/Telecommunications}

WHC-S-0400 (White 1995) calls for the seller to propose various data logging systems for use in the GEMS and to obtain buyer approval for the final choice. The buyer will then verify compatibility of the logging system with the existing host computer system. The existing host computer system uses the Gensym $\mathrm{G} 2^{\mathrm{TM}}$ software to communicate to external systems. The data logging system will have a standardized method of communicating with a host computer (i.e., RS232-C, RS-485, RS-449, etc.) for the transfer, on command, of recorded data values.

The data logging system will record the following information:

- Stack volumetric flow rate, and total flow,

- Volumetric flow rate and total flow for the record sampler and continuous monitor sample streams,

- Temperature of sample transport lines prior to entering the record sampler or continuous monitor,

- Stack gas temperature,

- Continuous monitor reading, and

- $\quad$ Stack gas relative humidity.

Project W-420 will not provide any telecommunications systems or devices.

\subsection{Safety Classification}

Safety classifications are identified for those Systems, Structures, or Components (SSCs) important to safety or environmental protection so that appropriate efforts will be placed on design, procurement, construction, testing, operation, maintenance, and modifications. Safety classification of SSCs are established in accordance with WHC manual WHC-CM-4-46, Safety Analysis Manual, section 9.0 (WHC 1996b) through analysis of the consequences of failure of the system, structure or component. WHC-SD-W420-FDC-001 (Lott 1996) states that the overall GEMS design shall be Safety Class 3 and that during Definitive Design, portions may be evaluated as Safety Class 2. The existing Safety Equipment Lists (WHC 1993a and WHC 1993b) for the double-shell tanks (including DCRTs) and the SSTs defines all stack monitors in this project as Safety Class 2. However, the most recent revision of Section 9.0 of WHC-CM-4-46 (WHC 1996b) no longer contains the same designations for Safety Class 1, 2, 3, or 4. Instead three designations are now used to define Safety Class, Safety Significant, and General Service SSCs.

Guidelines for assignment of the safety designation are found in Table 1, Section 9.0 of WHCCM-4-46 (WHC 1996b). Using these guidelines, the GEMS will most likely be designated as Safety Significant because it does not prevent or mitigate offsite public exposure in excess of 500 
mrem EDE which would require a safety class designation, but it does monitor the release of radioactive material to the environment after accidents where the monitor's output can initiate operator actions to place the operating process in a safe condition. A review of the design requirements in the safety analysis manual for this safety class reveals no requirements beyond those contained in the FDC. The stacks will be designated as General Service.

\subsection{Environmental Compliance}

The design, procurement, construction, and acceptance of Project W-420 will be governed by the applicable Federal, State, local, and site codes and regulations current at the time. The purpose of Project W-420 is to bring the stack monitoring into compliance with 40 CFR 61 Subpart $\mathrm{H}$ for identified stacks.

For National Environmental Policy Act (NEPA) purposes, installation of the GEMS is covered by the Waste Tanks Safety Program Environmental Assessment for which a Finding of No Significant Impact (FONSI) was signed on February 25, 1994 (Swan 1995).

\section{$5.8 \quad$ Permits}

Applicable Federal, State, and Hanford Site permits are discussed. All permits will be prepared and submitted to the appropriate regulatory agency by the Operations contractor (WHC).

\subsubsection{State and Federal Permits}

The following State and Federal permits may be required for Project W-420. This information was obtained from an Environmental Requirements Checklist (Swan 1995) conducted by WHC. If the checklist determined that a certain permit is not required, then it is not listed here.

\section{- $\quad$ Notice of Construction - WAC 246-247-060}

If modification to an existing emission source could cause an increase in the rate of emissions of radionuclides, then a Notice of Construction (NOC) is required by the Washington State Department of Health (DOH). There is no potential for increased emissions associated with installation of the new GEMS. However, a courtesy notice to the $\mathrm{DOH}$ is recommended. 
- Dangerous Waste Permit - WAC 173-303, 40 CFR 264, 265, and 270

Management of dangerous waste generated during project activities is required in accordance with the general provisions of WAC 173-303-200. Suspect waste materials, such as equipment or rags, should be managed as dangerous waste until confirmed by sampling and analysis. Waste designation can be based on process knowledge or from the results of sample and analysis. A review copy of the Project W-420 design package will be sent to the appropriate WHC organization for review and possible inclusion in the Site-Wide Hanford Facility RCRA Permit.

\subsubsection{Hanford Site Permits}

\section{- Excavation Permits}

An excavation permit for each area of work will be required prior to the start of construction. The permit will describe the area to be excavated, the allowed method(s) of excavation, and the necessary precautions to be taken.

\subsection{Uncertainties}

- Other upgrades planned under Project W-314, "Tank Farm Upgrades," for the facilities in this CDR are uncertain at this time and, therefore, future interfaces and avoidance of interferences must be closely monitored.

- The existing stack flow profiles had not been characterized at the time of this CDR. In order for detailed design to proceed, stack flow profiles should be taken to assure that sample and velocity probes will be able to be located appropriately.

- The future need for the 241-SX Exhauster is uncertain. If the exhauster is shut down, then a GEMS will not be installed.

- The vendor design of the GEMS has not been finalized and changes in configuration could affect the equipment layouts proposed in this CDR.

- In stacks with a diameter of 18 inches or more, it may be necessary to use two velocity probes perpendicular to each other in order to measure the flow velocity with the required accuracy. This is dependent upon the flow profile determined from stack characterization prior to detailed design.

- Currently, 244-BX and 244-S are in radiological buffer areas and, therefore, have fewer 
radiological control requirements than the other locations which are in contamination areas. If this situation changes, the cost of construction at 244-BX and 244-S could go up and the cost estimate would need to be adjusted.

- Exhauster shutdown times for the 296-P-16 and 296-S-15 stacks needs to be confirmed.

- Currently the design of the GEMS contains no air conditioning units for the cabinets. Some reviewers have questioned whether they will be needed. If air conditioning units are added and this in turn causes the power requirements to be increased, then the current electrical power supplies may be inadequate. In addition, the addition of air conditioning units would increase the cost of an individual GEMS unit.

In all cases, appropriate contingency has been provided to cover these uncertainties.

\subsection{REFERENCES}

ANSI N13.1-1969 (R1983), Guide to Sampling Radioactive Materials in Nuclear Facilities, American National Standards Institute.

ASHRAE, 1985, ASHRAE Handbook Fundamentals, American Society of Heating, Refrigeration, and Air-Conditioning Engineers.

Criddle, J.D., 1994, Functional Requirements Document for Measuring Emissions of Airborne Radioactive Materials, WHC-SD-WM-TI-288, rev. 0, Westinghouse Hanford Company, Richland, Washington.

Crummel, G.M., 1996, Tank Farm Stacks NESHAP Designation Determination, WHC-SD-WMEMP-031, rev. 2, Westinghouse Hanford Company, Richland, Washington.

DOE 1993, Hanford Site Radiological Control Manual, HSRCM-1, U.S., Department of Energy, Richland, Washington

DOE 6430.1A, General Design Criteria, U.S. Department of Energy, Washington, D.C.

Jones, J.M., 1996, 104/105/106-C and 244-CR Exhauster Shutdown Times, Record of Conversation, 96RL0308, ARES Corporation, Richland, Washington.

Kison, P.F., 1996, 241-SX Exhauster Shutdown Times, Record of Conversation, 96RL0307, ARES Corporation, Richland, Washington. 
Lott, D.T., 1996, Functional Design Criteria for Project W-420, Stack Monitoring Upgrade, WHC-SD-W420-FDC-001, draft, Westinghouse Hanford Company, Richland, Washington.

Swan, R.J., 1995, Environmental Requirements Checklist for the Gaseous Effluent Monitoring Systems, Internal Memo 01810-95-RJS-042, Westinghouse Hanford Company, Richland, Washington.

White, W.F., 1995, Procurement Specification for the Gaseous Effluent Monitoring System, WHC-S-0400, rev. 0, Westinghouse Hanford Company, Richland, Washington.

WHC, 1993a, Double Shell Tank Interim Safety Equipment List, WHC-SD-WM-SEL-026, rev. 1, Westinghouse Hanford Company, Richland, Washington.

WHC, 1993b, Single-Shell Tank Interim Safety Equipment List, WHC-SD-WM-SEL-027, rev, 0, Westinghouse Hanford Company, Richland, Washington.

WHC, 1994, Operating Specifications for the Saltwell Receiver Vessels, OSD-T-151-00011, rev. C-3, Westinghouse Hanford Company, Richland, Washington.

WHC, 1995a, Safety Manual, WHC-CM-1-10, Westinghouse Hanford Company, Richland, Washington.

WHC, 1995b, Tank Farm Health and Safety Plan, WHC-SD-WM-HSP-002, rev. 2, Westinghouse Hanford Company, Richland, Washington.

WHC, 1996a, Operating Specifications for Single-Shell Waste Storage Tanks, OSD-T-15100013, rev. B-8 Westinghouse Hanford Company, Richland, Washington.

WHC, 1996b, Safety Analysis Manual, WHC-CM-4-46, Westinghouse Hanford Company, Richland, Washington.

\subsection{Code of Federal Regulations (CFR)}

10 CFR 1910, Occupational Health and Safety

10 CFR 1926, Construction Safety

40 CFR 52 Appendix E, Performance Specifications and Specification Test Procedures for Monitoring Systems for Effluent Stream Gas Volumetric Flow Rate 


\begin{tabular}{lr} 
CONCEPTUAL DESIGN REPORT - STACK MONITORING SYSTEM & HNF-SD-W420-CDR-001, Rev. 0 \\
UPGRADES - PROJECT W-420 - Report No. 961129-001, Rev. 0 & September 1996 \\
\hline
\end{tabular}

40 CFR 60 Appendix A, Test Methods

40 CFR 61 Subpart H, National Emission Standards for Emissions of Radionuclides Other Than Radon from Department of Energy Facilities

\subsection{Drawings}

\begin{tabular}{|c|c|c|c|c|}
\hline \multirow[t]{3}{*}{$296-S-15$} & H-2-35835 & $\mathrm{H}-2-35834$ & $\mathrm{H}-2-35047$ & $\mathrm{H}-2-35832$ \\
\hline & H-2-35836 & H-2-74913 & $\mathrm{H}-2-46157$ & $\mathrm{H}-2-70613$ \\
\hline & H-2-95250 & H-2-90866 & H-2-74913 & \\
\hline \multirow[t]{3}{*}{ 296-B-28 } & H-2-73797 & H-2-73809 & H-2-73810 & H-14-03001 \\
\hline & H-2-73838 & H-2-73839 & H-2-73819 & H-2-73835 \\
\hline & H-2-73794 & $\mathrm{H}-2-73734$ & & \\
\hline \multirow[t]{2}{*}{$296-S-22$} & $\mathrm{H}-2-71047$ & $\mathrm{H}-2-71050$ & H-2-46785 & $\mathrm{H}-2-71093$ \\
\hline & $\mathrm{H}-2.71048$ & H-2-71092 & $\mathrm{H}-2-71090$ & $\mathrm{H}-2-73794$ \\
\hline \multirow[t]{2}{*}{$296-T-18$} & $\mathrm{H}-2-73796$ & $\mathrm{H}-2-73812$ & $\mathrm{H}-2-73818$ & $\mathrm{H}-2-73816$ \\
\hline & $\mathrm{H}-2-73838$ & H-2-73839 & $\mathrm{H}-2-73734$ & $\mathrm{H}-2-73794$ \\
\hline \multirow[t]{4}{*}{ 296-C-05 } & $\mathrm{H}-2-92519$ & $\mathrm{H}-2-41277$ & H-2-41928 & $\mathrm{H}-2-41930$ \\
\hline & $\mathrm{H}-2-92523$ & $\mathrm{H}-2-41781$ & $\mathrm{H}-2-41788$ & H-2-41789 \\
\hline & H-2-95308 & H-2-95309 & $\mathrm{H}-2-95310$ & $\mathrm{H}-2-95311$ \\
\hline & $\mathrm{H}-2-73794$ & & & \\
\hline \multirow[t]{5}{*}{ 296-P-16 } & H-2-35769 & H-2-36035 & H-2-93797 & $\mathrm{H}-2-95267$ \\
\hline & H-14-020113 & H-2-73957 & H-2-73948 & $\mathrm{H}-2-91116$ \\
\hline & H-2-95268 & $\mathrm{H}-2-95269$ & H-2-35544 & H-2-72195 \\
\hline & H-14-100290 & $\mathrm{H}-14-030013$ & H-2-34793 & H-2-93801 \\
\hline & $\mathrm{H}-2-73794$ & & & \\
\hline
\end{tabular}


296-A-25

$\begin{array}{llll}\text { H-2-38209 } & \text { H-2-38208 } & \text { H-2-38206 } & \text { H-2-95298 } \\ \text { H-2-95299 } & \text { H-2-92517 } & \text { H-2-38215 } & \text { H-2-71048 } \\ \text { H-2-71090 } & \text { H-2-73794 } & & \end{array}$


Appendix A

Cost Estimate Summary 


\section{Project $W-420$}

Stack Monitoring System Upgrades

Project Cost Summary

\begin{tabular}{|l|l|r|r|r|r|}
\hline $\begin{array}{l}\text { Cost } \\
\text { Code }\end{array}$ & Description & $\begin{array}{c}\text { Escalated } \\
\text { Total Cost }\end{array}$ & $\begin{array}{c}\% \\
\text { Contingency }\end{array}$ & $\begin{array}{c}\text { Total } \\
\text { Contingency }\end{array}$ & Total Dollars \\
\hline 000 & Engineering & $\$ 633,489$ & $26.2 \%$ & $\$ 166,022$ & $\$ 799,511$ \\
\hline 460 & Improvements to Land & $\$ 0$ & $0.0 \%$ & $\$ 0$ & $\$ 0$ \\
\hline 501 & Buildings & $\$ 0$ & $0.0 \%$ & $\$ 0$ & $\$ 0$ \\
\hline 550 & Other Structures & $\$ 0$ & $0.0 \%$ & $\$ 0$ & $\$ 0$ \\
\hline 600 & Utilities & $\$ 0$ & $0.0 \%$ & $\$ 0$ & $\$ 0$ \\
\hline 700 & Special Equip/Process Systems & $\$ 1,331,907$ & $30.0 \%$ & $\$ 399,572$ & $\$ 1,731,479$ \\
\hline \multirow{2}{*}{ Total Estimated Construction Cost } & & & & \\
\hline \multirow{2}{*}{ Other Project Costs } & $\$ 1,965,396$ & $28.8 \%$ & $\$ 565,594$ & $\$ 2,530,990$ \\
\hline \multirow{2}{*}{ Total Project Cost } & & & & \\
\hline \multicolumn{2}{|l|}{} & $\$ 551,290$ & $25.5 \%$ & $\$ 140,572$ & $\$ 691,863$ \\
\hline
\end{tabular}




\section{Project W-420 \\ Stack Monitor System Upgrades \\ General Notes}

1. General labor rates for onsite work are based on WHC rates utilized for previous coneceptual designs and are as follows:
a) Project Manager $\$ 76 / \mathrm{hr}$
b) Project Engineer $\$ 73 / \mathrm{hr}$
c) Design Engineer $\$ 73 / \mathrm{hr}$
d) Designer $\$ 61 / \mathrm{hr}$
e) Operators/HPTs $\$ 32 / \mathrm{hr}$
f) Site Construction $\$ 32 / \mathrm{hr}$
g) Admin. $\$ 28 / \mathrm{hr}$

2. Overhead and profit rates for offsite procurement was figured at $18 \%$ for materials (incl. sales tax) and and $53 \%$ for labor (based upon R.S. Means and past site practices).

3. LLW disposal burial rates used were $\$ 36.01$ per cubic foot (per phoncon with Rene Pedraza of WHC).

4. R.S. Means was used as a basis for determining construction labor hours and for procurement of manufactured equipment. Where experience indicated variations due to site specific circumstances, the changes were incorporated.

5. Escalation is based upon 3.2 percent annual inflation, and calculated to the midpoint of major activities.

6. A factor of $35 \%$ was employed to account for special work requirements associated with radiation work areas.

7. Documents used:

WHC-SD-W420-FDC-001, draft.

WHC-SD-W420-CDR-001, draft.

8. Material Prices

Unit costs represent current prices for specified material. Vendor information was obtained for the stack monitor.

9. Onsite construction forces general requirements, technical services, and craft overhead costs are included as a composite percentage based on the ICF-KH estimating factor, rev. 1, FY95, dated 1/18/94. The total composite percentage applied to onsite construction forces labor, for this project is $71 \%$ for shop work and $111 \%$ for field work, which is reflected in the Overhead/Profit column of the estimate detail. 


\section{Project $W-420$ \\ Stack Monitoring System Upgrades}

Project Summary by WBS

\begin{tabular}{|c|c|c|c|c|c|c|c|c|}
\hline & & $\begin{array}{l}\text { Estimate } \\
\text { Subtotal }\end{array}$ & \multicolumn{2}{|c|}{ Escalation } & \multirow[t]{2}{*}{ Subtotal } & \multicolumn{2}{|c|}{ Contingency } & Total Dollars \\
\hline WBS & Activity & & $\%$ & Total & & $\%$ & Total & \\
\hline 1.1 & Design & $\$ 475,742$ & $9.3 \%$ & $\$ 44,244$ & $\$ 519,986$ & $27.0 \%$ & $\$ 140,396$ & $\$ 660,383$ \\
\hline 1.2 & Procurement & $\$ 639,250$ & $9.9 \%$ & $\$ 63,286$ & $\$ 702,535$ & $30.0 \%$ & $\$ 210,761$ & $\$ 913,296$ \\
\hline 1.3 & Construction & $\$ 561,939$ & $12.0 \%$ & $\$ 67,433$ & $\$ 629,371$ & $30.0 \%$ & $\$ 188,811$ & $\$ 818,183$ \\
\hline 1.4 & Project Management & $\$ 235,672$ & $6.5 \%$ & $\$ 15,319$ & $\$ 250,991$ & $25.0 \%$ & $\$ 62,748$ & $\$ 313,738$ \\
\hline 1.5 & Other Project Costs & $\$ 366,846$ & $12.8 \%$ & $\$ 46,956$ & $\$ 413,802$ & $25.0 \%$ & $\$ 103,451$ & $\$ 517,253$ \\
\hline TOTAL & & $\$ 2,279,449$ & $10.4 \%$ & $\$ 237,237$ & $\$ 2,516,686$ & $28.1 \%$ & $\$ 706,167$ & $\$ 3,222,853$ \\
\hline
\end{tabular}

Notes:

1) Design contingency was set at $27 \%$ due to the lack of existing drawing details and the possibility of vendor changes in the monitor design.

2) Procurement contingency was set at $30 \%$ even with a quote from the vendor due to lack of stack flow characteristics and the possiblity of future design changes.

3) Construction contingency was set at $30 \%$ due to unknown subsurface interferences and small working quarters.

4) Project management contingency was set at $25 \%$ as the project duration and project personnel are fairly well defined. 


\section{Project W-420}

Stack Monitoring System Upgrades

Estimate Details for Conceptual Design Activities

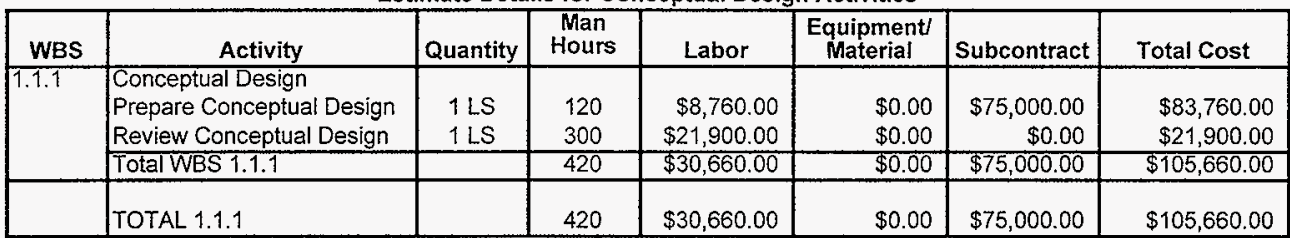

Notes: Conceptual Design estimate is per proposal from ARES Corp. 


\section{Project $\mathbf{W}-420$}

Stack Monitoring System Upgrades

Estimate Details for Detailed Design Activities (296-A-25)

\begin{tabular}{|c|c|c|c|c|c|c|c|}
\hline WBS & Activity & Quantity & $\begin{array}{l}\text { Man } \\
\text { Hours } \\
\end{array}$ & Labor & $\begin{array}{l}\text { Equipment/ } \\
\text { Material }\end{array}$ & $\begin{array}{c}\text { Overhead } \\
\text { Profit }\end{array}$ & Total Cost \\
\hline \multirow[t]{6}{*}{1.1 .2 .1 .1} & Drawings & & & & & & \\
\hline & Site Plan & $1 \mathrm{LS}$ & 80 & $\$ 4,880.00$ & $\$ 0.00$ & $\$ 0.00$ & $\$ 4,880.00$ \\
\hline & Stack drawing & $1 \mathrm{LS}$ & 80 & $\$ 4,880.00$ & $\$ 0.00$ & $\$ 0.00$ & $\$ 4,880.00$ \\
\hline & Electrical drawings & $1 \mathrm{LS}$ & 80 & $\$ 4,880.00$ & $\$ 0.00$ & $\$ 0.00$ & $\$ 4,880.00$ \\
\hline & Work Platform & $1 \mathrm{LS}$ & 80 & $\$ 4,880.00$ & $\$ 0.00$ & $\$ 0.00$ & $\$ 4,880.00$ \\
\hline & Total WBS 1.1.2.1.1 & & 320 & $\$ 19,520.00$ & $\$ 0.00$ & $\$ 0.00$ & $\$ 19,520.00$ \\
\hline \multirow[t]{4}{*}{1.1 .2 .1 .2} & Design Calculations & & & & & & \\
\hline & Preliminary Stack Calcs & $1 \mathrm{LS}$ & 40 & $\$ 2,920.00$ & $\$ 0.00$ & $\$ 0.00$ & $\$ 2,920.00$ \\
\hline & Platform Calcs & $1 \mathrm{LS}$ & 30 & $\$ 2,190.00$ & $\$ 0.00$ & $\$ 0.00$ & $\$ 2,190.00$ \\
\hline & Total WBS 1.1.2.1.2 & & 70 & $\$ 5,110.00$ & $\$ 0.00$ & $\$ 0.00$ & $\$ 5,110.00$ \\
\hline \multirow{6}{*}{1.1 .2 .1 .3} & Specifications & & & & & & \\
\hline & Stack Monitor Data Sheet & $1 \mathrm{LS}$ & 10 & $\$ 730.00$ & $\$ 0.00$ & $\$ 0.00$ & $\$ 730.00$ \\
\hline & Stack Specification & $1 \mathrm{LS}$ & 40 & $\$ 2,920.00$ & $\$ 0.00$ & $\$ 0.00$ & $\$ 2,920.00$ \\
\hline & Platform Specification & $1 \mathrm{LS}$ & 30 & $\$ 2,190.00$ & $\$ 0.00$ & $\$ 0.00$ & $\$ 2,190.00$ \\
\hline & Total WBS 1.1.2.1.3 & & 80 & $\$ 5,840.00$ & $\$ 0.00$ & $\$ 0.00$ & $\$ 5,840.00$ \\
\hline & TOTAL 1.1.2.1 & & 470 & $\$ 30,470.00$ & $\$ 0.00$ & $\$ 0.00$ & $\$ 30,470.00$ \\
\hline
\end{tabular}


HNF-SD-W420-CDR-001, Rev. 0

\section{Project W-420}

Stack Monitoring System Upgrades

Estimate Details for Detailed Design Activities (296-B-28)

\begin{tabular}{|c|c|c|c|c|c|c|c|}
\hline WBS & Activity & Quantity & $\begin{array}{l}\text { Man } \\
\text { Hours }\end{array}$ & Labor & $\begin{array}{c}\text { Equipment/ } \\
\text { Material }\end{array}$ & $\begin{array}{c}\text { Overhead } \\
\text { Profit }\end{array}$ & Total Cost \\
\hline \multirow[t]{5}{*}{1.1 .2 .2 .1} & Drawings & & 80 & $\$ 488000$ & $\$ 000$ & $\$ 000$ & $\$ 488000$ \\
\hline & $\begin{array}{l}\text { Site Plan } \\
\text { Stack drawing }\end{array}$ & $\begin{array}{l}1 \mathrm{LS} \\
1 \mathrm{LS}\end{array}$ & 80 & $\begin{array}{l}\$ 4,880.00 \\
\$ 4,880.00\end{array}$ & $\begin{array}{l}\$ 0.00 \\
\$ 0.00\end{array}$ & $\begin{array}{l}\$ 0.00 \\
\$ 0.00\end{array}$ & $\begin{array}{l}\$ 4,880.00 \\
\$ 4,880.00\end{array}$ \\
\hline & Electrical drawings & $1 \mathrm{LS}$ & 80 & $\$ 4,880.00$ & $\$ 0.00$ & $\$ 0.00$ & $\$ 4,880.00$ \\
\hline & Work Platform & $1 \mathrm{LS}$ & 80 & $\$ 4,880.00$ & $\$ 0.00$ & $\$ 0.00$ & $\$ 4,880.00$ \\
\hline & TotalWBS 1.1.2.2.1 & & 320 & $\$ 19,520.00$ & $\$ 0.00$ & $\$ 0.00$ & $\$ 19,520.00$ \\
\hline \multirow[t]{4}{*}{1.1 .2 .2 .2} & Design Calculations & & & & & & \\
\hline & Preliminary Stack Calcs & $1 \mathrm{LS}$ & 40 & $\$ 2,920.00$ & $\$ 0.00$ & $\$ 0.00$ & $\$ 2,920.00$ \\
\hline & Platform Calcs & $1 \mathrm{LS}$ & 30 & $\$ 2,190.00$ & $\$ 0.00$ & $\$ 0.00$ & $\$ 2,190.00$ \\
\hline & Total WBS 1.1.2.2.2 & & 70 & $\$ 5,110.00$ & $\$ 0.00$ & $\$ 0.00$ & $\$ 5,110.00$ \\
\hline \multirow[t]{5}{*}{1.1 .2 .2 .3} & Speciffcations & & & & & & \\
\hline & Stack Monitor Data Sheet & $1 \mathrm{LS}$ & 10 & $\$ 730.00$ & $\$ 0.00$ & $\$ 0.00$ & $\$ 730.00$ \\
\hline & Stack Specification & $1 \mathrm{LS}$ & 40 & $\$ 2,920.00$ & $\$ 0.00$ & $\$ 0.00$ & $\$ 2,920.00$ \\
\hline & Platform Specification & $1 \mathrm{LS}$ & 30 & $\$ 2,190.00$ & $\$ 0.00$ & $\$ 0.00$ & $\$ 2,190.00$ \\
\hline & Total WBS 1.1.2.2.3 & & 80 & $\$ 5,840,00$ & $\$ 0.00$ & $\$ 0.00$ & $\$ 5,840.00$ \\
\hline & TOTAL 1.1.2.2 & & 470 & $\$ 30,470.00$ & $\$ 0.00$ & $\$ 0.00$ & $\$ 30,470.00$ \\
\hline
\end{tabular}


HNF-SD-W420-CDR-001, Rev. 0

\section{Project W-420}

Stack Monitoring System Upgrades

Estimate Details for Detailed Design Activities (296-S-22)

\begin{tabular}{|c|c|c|c|c|c|c|c|}
\hline WBS & Activity & Quantity & $\begin{array}{l}\text { Man } \\
\text { Hours }\end{array}$ & Labor & $\begin{array}{l}\text { Equipment/ } \\
\text { Material }\end{array}$ & $\begin{array}{l}\text { Overhead } \\
\text { Profit }\end{array}$ & Total Cost \\
\hline \multirow[t]{6}{*}{1.1 .2 .3 .1} & Drawings & & & & & & \\
\hline & Site Plan & $1 \mathrm{LS}$ & 80 & $\$ 4,880.00$ & $\$ 0.00$ & $\$ 0.00$ & $\$ 4,880.00$ \\
\hline & Stack drawing & $1 \mathrm{LS}$ & 80 & $\$ 4,880.00$ & $\$ 0.00$ & $\$ 0.00$ & $\$ 4,880.00$ \\
\hline & Electrical drawings & $1 \mathrm{LS}$ & 80 & $\$ 4,880.00$ & $\$ 0.00$ & $\$ 0.00$ & $\$ 4,880.00$ \\
\hline & Work Platform & $1 \mathrm{LS}$ & 80 & $\$ 4,880.00$ & $\$ 0.00$ & $\$ 0.00$ & $\$ 4,880.00$ \\
\hline & Total WBS 1.1.2.3.1 & & 320 & $\$ 19,520.00$ & $\$ 0.00$ & $\$ 0.00$ & $\$ 19,520.00$ \\
\hline \multirow[t]{4}{*}{$1.1,2.3 .2$} & Design Calculations & & & & & & \\
\hline & Preliminary Stack Calcs & $1 \mathrm{LS}$ & 40 & $\$ 2,920.00$ & $\$ 0.00$ & $\$ 0.00$ & $\$ 2,920.00$ \\
\hline & Platform Calcs & $1 \mathrm{LS}$ & 30 & $\$ 2,190.00$ & $\$ 0.00$ & $\$ 0.00$ & $\$ 2,190.00$ \\
\hline & Total WBS 1.1.2.3.2 & & 70 & $\$ 5,110.00$ & $\$ 0.00$ & $\$ 0.00$ & $\$ 5,110.00$ \\
\hline \multirow[t]{5}{*}{1.1 .2 .3 .3} & Specifications & & & & & & \\
\hline & Stack Monitor Data Sheet & $1 \mathrm{LS}$ & 10 & $\$ 730.00$ & $\$ 0.00$ & $\$ 0.00$ & $\$ 730.00$ \\
\hline & Stack Specification & $1 \mathrm{LS}$ & 40 & $\$ 2,920.00$ & $\$ 0.00$ & $\$ 0.00$ & $\$ 2,920.00$ \\
\hline & Platform Specification & $1 \mathrm{LS}$ & 30 & $\$ 2,190.00$ & $\$ 0.00$ & $\$ 0.00$ & $\$ 2,190.00$ \\
\hline & Total WBS 1.1.2.3.3 & & 80 & $\$ 5,840.00$ & $\$ 0.00$ & $\$ 0.00$ & $\$ 5,840.00$ \\
\hline & TOTAL 1.1.2.3 & & 470 & $\$ 30,470.00$ & $\$ 0.00$ & $\$ 0.00$ & $\$ 30,470.00$ \\
\hline
\end{tabular}




\section{Project W-420}

Stack Monitoring System Upgrades

Estimate Details for Detailed Design Activities (296-T-18)

\begin{tabular}{|c|c|c|c|c|c|c|c|}
\hline WBS & Activity & Quantity & $\begin{array}{l}\text { Man } \\
\text { Hours }\end{array}$ & Labor & $\begin{array}{l}\text { Equipment/ } \\
\text { Material }\end{array}$ & $\begin{array}{c}\text { Overhead } \\
\text { Profit }\end{array}$ & Total Cost \\
\hline \multirow[t]{6}{*}{$\mid 1.1 .2 .4 .1$} & Drawings & & & & & & \\
\hline & Site Plan & $1 \mathrm{LS}$ & 80 & $\$ 4,880.00$ & $\$ 0.00$ & $\$ 0.00$ & $\$ 4,880.00$ \\
\hline & Stack drawing & $1 \mathrm{LS}$ & 80 & $\$ 4,880.00$ & $\$ 0.00$ & $\$ 0.00$ & $\$ 4,880.00$ \\
\hline & Electrical drawings & $1 \mathrm{LS}$ & 80 & $\$ 4,880.00$ & $\$ 0.00$ & $\$ 0.00$ & $\$ 4,880.00$ \\
\hline & Work Platform & $1 \mathrm{LS}$ & 80 & $\$ 4,880.00$ & $\$ 0.00$ & $\$ 0.00$ & $\$ 4,880.00$ \\
\hline & Total WBS 1.1.2.4.1 & & 320 & $\$ 19,520.00$ & $\$ 0.00$ & $\$ 0.00$ & $\$ 19,520.00$ \\
\hline \multirow[t]{4}{*}{1.1 .2 .4 .2} & Design Calculations & & & & & & \\
\hline & Preliminary Stack Calcs & $1 \mathrm{LS}$ & 40 & $\$ 2,920.00$ & $\$ 0.00$ & $\$ 0.00$ & $\$ 2,920.00$ \\
\hline & Platform Calcs & $1 \mathrm{LS}$ & 30 & $\$ 2,190.00$ & $\$ 0.00$ & $\$ 0.00$ & $\$ 2,190,00$ \\
\hline & Total WBS 1.1.2.4.2 & & 70 & $\$ 5,110.00$ & $\$ 0.00$ & $\$ 0.00$ & $\$ 5,110.00$ \\
\hline \multirow[t]{5}{*}{ 1.1.2.4.3 } & Specifications & & & & & & \\
\hline & Stack Monitor Data Sheet & $1 \mathrm{LS}$ & 10 & $\$ 730.00$ & $\$ 0.00$ & $\$ 0.00$ & $\$ 730.00$ \\
\hline & Stack Specification & $1 \mathrm{LS}$ & 40 & $\$ 2,920.00$ & $\$ 0.00$ & $\$ 0.00$ & $\$ 2,920.00$ \\
\hline & Platform Specification & $1 \mathrm{LS}$ & 30 & $\$ 2,190.00$ & $\$ 0.00$ & $\$ 0.00$ & $\$ 2,190.00$ \\
\hline & Total WBS 1.1.2.4.3 & & 80 & $\$ 5,840.00$ & $\$ 0.00$ & $\$ 0.00$ & $\$ 5,840.00$ \\
\hline & TOTAL 1.1.2.4 & & 470 & $\$ 30,470.00$ & $\$ 0.00$ & $\$ 0.00$ & $\$ 30,470.00$ \\
\hline
\end{tabular}


HNF-SD-W420-CDR-001, Rev. 0

\section{Project $W-420$}

Stack Monitoring System Upgrades

Estimate Details for Detailed Design Activities (296-C-05)

\begin{tabular}{|c|c|c|c|c|c|c|c|}
\hline WBS & Activity & Quantity & $\begin{array}{l}\text { Man } \\
\text { Hours } \\
\end{array}$ & Labor & $\begin{array}{c}\text { Equipment/ } \\
\text { Material }\end{array}$ & $\begin{array}{c}\text { Overhead } \\
\text { Profit }\end{array}$ & Total Cost \\
\hline \multirow[t]{6}{*}{1.1 .2 .5 .1} & Drawings & & & & & & \\
\hline & Site Plan & $1 \mathrm{LS}$ & 80 & $\$ 4,880.00$ & $\$ 0.00$ & $\$ 0.00$ & $\$ 4,880.00$ \\
\hline & Stack modification drawing & $1 \mathrm{LS}$ & 80 & $\$ 4,8$ & $\$ 0.00$ & $\$ 0.00$ & $\$ 4,880.00$ \\
\hline & Electrical drawings & $1 \mathrm{LS}$ & 80 & $\$ 4,880.00$ & $\$ 0.00$ & $\$ 0.00$ & $\$ 4,880.00$ \\
\hline & Work Platform & $1 \mathrm{LS}$ & 80 & $\$ 4,880.00$ & $\$ 0.00$ & $\$ 0.00$ & $\$ 4,880.00$ \\
\hline & Total WBS 1.1.2.5.1 & & 320 & $\$ 19.520 .00$ & $\$ 0.00$ & $\$ 0.00$ & $\$ 19,520.00$ \\
\hline \multirow[t]{4}{*}{1.1 .2 .5 .2} & Design Calculations & & & & & & \\
\hline & Stack Mod. Calcs & $1 \mathrm{LS}$ & 60 & $\$ 4,380.00$ & $\$ 0.00$ & $\$ 0.00$ & $\$ 4,380.00$ \\
\hline & Platform Calcs & 1 & 40 & & & & 0.00 \\
\hline & Total WBS 1.1.2.5.2 & & 100 & $\$ 7,300.00$ & $\$ 0.00$ & $\$ 0.00$ & $\$ 7,300.00$ \\
\hline \multirow[t]{5}{*}{1.1 .2 .5 .3} & Specifications & & & & & & \\
\hline & Stack Monitor Data Sheet & $1 \mathrm{LS}$ & 20 & $\$ 1,460.00$ & $\$ 0.00$ & $\$ 0.00$ & $\$ 1,460.00$ \\
\hline & Platform Specification & $1 \mathrm{LS}$ & 50 & .00 & $\$ 0.00$ & $\$ 0.00$ & 50.00 \\
\hline & Total WBS 1.1.2.5.3 & & 70 & $\$ 5.110 .00$ & $\$ 0.00$ & $\$ 0.00$ & $\$ 5,110.00$ \\
\hline & TOTAL 1.1.2.5 & & 490 & $\$ 31,930.00$ & $\$ 0.00$ & $\$ 0.00$ & $\$ 31,930.00$ \\
\hline
\end{tabular}




\section{Project W-420}

Stack Monitoring System Upgrades

Estimate Details for Detailed Design Activities (296-P-16)

\begin{tabular}{|c|c|c|c|c|c|c|c|}
\hline WBS & Activity & Quantity & $\begin{array}{l}\text { Man } \\
\text { Hours }\end{array}$ & Labor & $\begin{array}{c}\text { Equipment } \\
\text { Material }\end{array}$ & $\begin{array}{c}\text { Overhead } \\
\text { Profit }\end{array}$ & Total Cost \\
\hline \multirow[t]{6}{*}{1.1 .2 .6 .1} & Drawings & & & & & & \\
\hline & Site Plan & $1 \mathrm{LS}$ & 80 & $\$ 4,880.00$ & $\$ 0.00$ & $\$ 0.00$ & $\$ 4,880.00$ \\
\hline & Stack drawing & 1 LS & 120 & $\$ 7,320.00$ & $\$ 0.00$ & $\$ 0.00$ & $\$ 7,320.00$ \\
\hline & Electrical drawings & $1 \mathrm{LS}$ & 80 & $\$ 4,880.00$ & $\$ 0.00$ & $\$ 0.00$ & $\$ 4,880.00$ \\
\hline & Work Platform & $1 \mathrm{LS}$ & 80 & $\$ 4,880.00$ & $\$ 0.00$ & $\$ 0.00$ & $\$ 4,880.00$ \\
\hline & Total WBS 1.1.2.6.1 & & 360 & $\$ 21,960.00$ & $\$ 0.00$ & $\$ 0.00$ & $\$ 21,960.00$ \\
\hline \multirow[t]{4}{*}{1.1 .2 .6 .2} & Design Calculations & & & & & & \\
\hline & Stack Mod. Calcs & $1 \mathrm{LS}$ & 40 & $\$ 2,920.00$ & $\$ 0.00$ & $\$ 0.00$ & $\$ 2,920.00$ \\
\hline & Platform Calcs & $1 \mathrm{LS}$ & 30 & $\$ 2,190.00$ & $\$ 0.00$ & $\$ 0.00$ & $\$ 2,190.00$ \\
\hline & Total WBS 1.1.2.6.2 & & 70 & $\$ 5,110.00$ & $\$ 0.00$ & $\$ 0.00$ & $\$ 5,110.00$ \\
\hline \multirow[t]{5}{*}{1.1 .2 .6 .3} & Specifications & & & & & & \\
\hline & Stack Monitor Data Sheet & $1 \mathrm{LS}$ & 20 & $\$ 1,460.00$ & $\$ 0.00$ & $\$ 0.00$ & $\$ 1,460.00$ \\
\hline & Stack Specification & $1 \mathrm{LS}$ & 80 & $\$ 5,840.00$ & $\$ 0.00$ & $\$ 0.00$ & $\$ 5,840.00$ \\
\hline & Platform Specification & $1 \mathrm{LS}$ & 30 & $\$ 2,190.00$ & $\$ 0.00$ & $\$ 0.00$ & $\$ 2,190.00$ \\
\hline & Total WBS 1.1.2.6.3 & & 130 & $\$ 9,490.00$ & $\$ 0.00$ & $\$ 0.00$ & $\$ 9,490.00$ \\
\hline & TOTAL 1.1.2.6 & & 560 & $\$ 36,560.00$ & $\$ 0.00$ & $\$ 0.00$ & $\$ 36,560.00$ \\
\hline
\end{tabular}


HNF-SD-W420-CDR-001, Rev. 0

\section{Project W-420}

Stack Monitoring System Upgrades

Estimate Details for Detailed Design Activities (296-S-15)

\begin{tabular}{|c|c|c|c|c|c|c|c|}
\hline WBS & Activity & Quantity & $\begin{array}{c}\text { Man } \\
\text { Hours } \\
\end{array}$ & Labor & $\begin{array}{c}\text { Equipment/ } \\
\text { Material }\end{array}$ & $\begin{array}{c}\text { Overhead } \\
\text { Profit } \\
\end{array}$ & Total Cost \\
\hline 1.1 .2 .7 .1 & \begin{tabular}{|l} 
Drawings \\
Site Plan \\
Stack drawing \\
Electrical drawings \\
Work Platform \\
Total WBS 1.1.2.1.
\end{tabular} & $\begin{array}{l}1 \mathrm{LS} \\
1 \mathrm{LS} \\
1 \mathrm{LS} \\
1 \mathrm{LS}\end{array}$ & $\begin{array}{c}80 \\
120 \\
80 \\
80 \\
360\end{array}$ & $\begin{array}{r}\$ 4,880.00 \\
\$ 7,320.00 \\
\$ 4,880.00 \\
\$ 4,880.00 \\
21,960.00\end{array}$ & $\begin{array}{l}\$ 0.00 \\
\$ 0.00 \\
\$ 0.00 \\
\$ 0.00 \\
\$ 0.00\end{array}$ & $\begin{array}{l}\$ 0.00 \\
\$ 0.00 \\
\$ 0.00 \\
\$ 0.00 \\
\$ 0.00\end{array}$ & $\begin{array}{r}\$ 4,880.00 \\
\$ 7,320.00 \\
\$ 4,880.00 \\
\$ 4,880.00 \\
\$ 21,960.00\end{array}$ \\
\hline 1.1 .2 .7 .2 & $\begin{array}{l}\text { Design Calculations } \\
\text { Preliminary Stack Calcs } \\
\text { Platform Calcs } \\
\text { Total WBS 1.1.2.7.2 }\end{array}$ & $\begin{array}{l}1 \mathrm{LS} \\
1 \mathrm{LS}\end{array}$ & $\begin{array}{l}60 \\
40 \\
100\end{array}$ & $\begin{array}{l}\$ 4,380.00 \\
\$ 2,920.00 \\
\$ 7,300.00\end{array}$ & $\begin{array}{l}\$ 0.00 \\
\$ 0.00 \\
\$ 0.00\end{array}$ & $\begin{array}{l}\$ 0.00 \\
\$ 0.00 \\
\$ 0.00\end{array}$ & $\begin{array}{l}\$ 4,380.00 \\
\$ 2,920.00 \\
\$ 7,300.00\end{array}$ \\
\hline 1.1 .2 .7 .3 & $\begin{array}{l}\text { Specifications } \\
\text { Stack Monitor Data Sheet } \\
\text { Stack Specification } \\
\text { Platform Specification } \\
\text { TotalWBS 1.1.2.7.3 }\end{array}$ & $\begin{array}{l}1 \mathrm{LS} \\
1 \mathrm{LS} \\
1 \mathrm{LS}\end{array}$ & $\begin{array}{l}20 \\
80 \\
50 \\
150\end{array}$ & $\begin{array}{r}\$ 1,460.00 \\
\$ 5,840.00 \\
\$ 3,650.00 \\
\$ 10,950.00\end{array}$ & $\begin{array}{l}\$ 0.00 \\
\$ 0.00 \\
\$ 0.00 \\
\$ 0.00\end{array}$ & $\begin{array}{l}\$ 0.00 \\
\$ 0.00 \\
\$ 0.00 \\
\$ 0.00\end{array}$ & $\begin{array}{r}\$ 1,460.00 \\
\$ 5,840.00 \\
\$ 3,650.00 \\
\$ 10,950.00\end{array}$ \\
\hline & TOTAL 1.1.2.7 & & 610 & $\$ 40,210.00$ & $\$ 0.00$ & $\$ 0.00$ & $\$ 40,210.00$ \\
\hline 1.1 .2 & Design Review & $1 \mathrm{LS}$ & 400 & $\$ 29,200.00$ & $\$ 0.00$ & $\$ 0.00$ & $\$ 29,200.00$ \\
\hline & TOTAL 1.1.2 & & 3940 & $\$ 259,780.00$ & $\$ 0.00$ & $\$ 0.00$ & $\$ 259,780.00$ \\
\hline
\end{tabular}

Notes:

1) All drawings determined at 80 hrs. per sheet, and will primarily be Engineering Change Notices.

2) Procurement specifications are prorated between stacks.

3) Design Review assumes 5 engineers for two weeks. 
HNF-SD-W420-CDR-001, Rev. 0

\section{Project W-420}

Stack Monitoring System Upgrades

Estimate Details for Field Engineering and Inspection Activities

\begin{tabular}{|c|c|c|c|c|c|c|c|}
\hline WBS & Activity & Quantity & $\begin{array}{l}\text { Man } \\
\text { Hours } \\
\end{array}$ & Labor & $\begin{array}{l}\text { Equipment/ } \\
\text { Material }\end{array}$ & $\begin{array}{c}\text { Overhead/ } \\
\text { Profit }\end{array}$ & Total Cost \\
\hline \multirow[t]{2}{*}{1.1 .3} & $\begin{array}{l}\text { Field Engineiring and Insp. } \\
\text { Field Engineer } \\
\text { A } 1\end{array}$ & $\begin{array}{l}1 \mathrm{LS} \\
1 \mathrm{LS}\end{array}$ & $\begin{array}{c}1400 \\
120\end{array}$ & $\begin{array}{r}\$ 102,200.00 \\
\$ 3,840.00\end{array}$ & $\begin{array}{l}\$ 0.00 \\
\$ 0.00\end{array}$ & $\begin{array}{r}\$ 0.00 \\
\$ 4,262.40\end{array}$ & $\begin{array}{r}\$ 102,200,00 \\
\$ 8,102.40\end{array}$ \\
\hline & Total WBS 1.1.3 & & 1520 & $\$ 106,040.00$ & $\$ 0.00$ & $\$ 4,262.40$ & $\$ 110,302.40$ \\
\hline & OTAL WBS 1.1 & & 5880 & $\$ 396,480.00$ & $\$ 0.00$ & $\$ 79,262.40$ & $\$ 475$ \\
\hline
\end{tabular}




\section{Project $W-420$}

Stack Monitoring System Upgrades

Procurement Activities

\begin{tabular}{|c|c|c|c|c|c|c|c|}
\hline WBS & Activity & Quantity & $\begin{array}{l}\text { Man } \\
\text { Hours }\end{array}$ & Labor & $\begin{array}{c}\text { Equipment/ } \\
\text { Material }\end{array}$ & Subcontract & Total Cost \\
\hline \multirow[t]{2}{*}{1.2 .1} & Procure Stack Monitors & $1 \mathrm{LS}$ & & & & $\$ 585,280.00$ & $\$ 585,280.00$ \\
\hline & Total WBS 1.2.1 & & & & & $\$ 585,280.00$ & $\$ 585,280.00$ \\
\hline 1.2 .2 & Procure Work Platforms & & & & & & \\
\hline 1.2 .2 .1 & 296-A-25 & $1 \mathrm{LS}$ & & & & $\$ 3,658.26$ & $\$ 3,658.26$ \\
\hline 1.2 .2 .2 & $296-B-28$ & $1 \mathrm{LS}$ & & & & $\$ 4,071.36$ & $\$ 4,071.36$ \\
\hline 1.2 .2 .3 & $296-S-22$ & $1 \mathrm{LS}$ & & & & $\$ 4,071.36$ & $\$ 4,071.36$ \\
\hline 1.2 .2 .4 & 296-T-18 & $1 \mathrm{LS}$ & & & & $\$ 4,071.36$ & $\$ 4,071.36$ \\
\hline 1.2 .2 .5 & $296-C-05$ & $1 \mathrm{LS}$ & & & & $\$ 7,066.17$ & $\$ 7,066.17$ \\
\hline 1.2 .2 .6 & 296-P-16 & $1 \mathrm{LS}$ & & & & $\$ 4,970.52$ & $\$ 4,970.52$ \\
\hline \multirow[t]{2}{*}{ 1.2.2.7 } & $296-S-15$ & $1 \mathrm{LS}$ & & & & $\$ 7,066.17$ & $\$ 7,066.17$ \\
\hline & Total WBS 1.2 .2 & & & & & $\$ 34,975.22$ & $\$ 34,975.22$ \\
\hline 1.2 .3 & Procure Stack Sections & & & & & & \\
\hline 1.2.3.1 & $296-A-25$ & $1 \mathrm{LS}$ & & & & $\$ 2,281.88$ & $\$ 2,281.88$ \\
\hline 1.2 .3 .2 & 296-B-28 & $1 \mathrm{LS}$ & & & & $\$ 2,281.88$ & $\$ 2,281.88$ \\
\hline 1.2 .3 .3 & $296-S-22$ & $1 \mathrm{LS}$ & & & & $\$ 2,281,88$ & $\$ 2,281.88$ \\
\hline 1.2 .3 .4 & $296-\mathrm{T}-18$ & $1 \mathrm{LS}$ & & & & $\$ 2,281.88$ & $\$ 2,281.88$ \\
\hline 1.2 .3 .6 & $296-P-16$ & $1 \mathrm{LS}$ & & & & $\$ 4,371.17$ & $\$ 4,371.17$ \\
\hline \multirow[t]{2}{*}{ 1.2.3.7 } & $296-\mathrm{S}-15$ & $1 \mathrm{LS}$ & & & & $\$ 5,495.71$ & $\$ 5,495.71$ \\
\hline & Total WBS 1.2 .3 & & & & & $\$ 18,994.40$ & $\$ 18,994,40$ \\
\hline & TOTAL 1.2 & & & & & $\$ 639,249.62$ & $\$ 639,249.62$ \\
\hline
\end{tabular}

Notes:

1) Cost of Stack Monitors includes recommended alpha monitors. Cost is based on stack monitor procured from vendor. 


\section{Project $W-420$}

Stack Monitoring System Upgrades

Estimate Details for Construction Activities (296-A-25)

\begin{tabular}{|c|c|c|c|c|c|c|c|}
\hline WBS & Activity & Quantity & $\begin{array}{l}\text { Man } \\
\text { Hours }\end{array}$ & Labor & $\begin{array}{c}\text { Equipment } \\
\text { Material }\end{array}$ & $\begin{array}{c}\text { Overhead } \\
\text { Profit }\end{array}$ & Total Cost \\
\hline 1.3 .1 .1 & $\begin{array}{l}\text { Site Work/Demolition } \\
\text { Deenergize and tagout equip. } \\
\text { Remove Existing Monitor } \\
\text { Remove Existing Stack } \\
\text { TotalWBS } 1.3 .1 .1\end{array}$ & $\begin{array}{l}1 \text { LS } \\
1 \text { LS } \\
1 \text { LS }\end{array}$ & $\begin{array}{c}8 \\
24 \\
24 \\
56\end{array}$ & $\begin{array}{r}\$ 256.00 \\
\$ 768.00 \\
\$ 768.00 \\
\$ 1,792.00\end{array}$ & $\begin{array}{l}\$ 0.00 \\
\$ 0.00 \\
\$ 0.00 \\
\$ 0.00\end{array}$ & $\begin{array}{l}\$ 284.16 \\
\$ 852.48 \\
\$ 852.48 \\
1,989.12\end{array}$ & $\begin{array}{r}\$ 540.16 \\
\$ 1,620.48 \\
\$ 1,620.48 \\
\$ 3,781.12\end{array}$ \\
\hline 1.3 .1 .2 & $\begin{array}{l}\text { Support Pad - 5'x7' } \\
\text { Excavation } \\
\text { Form Work } \\
\text { Pour cement } \\
\text { Finish Work } \\
\text { Hilti-Bolt Embeds } \\
\text { Total WBS 1.3.1.2 }\end{array}$ & $\begin{array}{l}1 \mathrm{CY} \\
24 \mathrm{LF} \\
1 \mathrm{CY} \\
35 \mathrm{SF} \\
1 \mathrm{LS}\end{array}$ & $\begin{array}{c}16 \\
24 \\
8 \\
8 \\
24 \\
80\end{array}$ & $\begin{array}{r}\$ 512.00 \\
\$ 768.00 \\
\$ 256.00 \\
\$ 256.00 \\
\$ 768.00 \\
\$ 2,560.00\end{array}$ & $\begin{array}{r}\$ 0.00 \\
\$ 15.00 \\
\$ 60.00 \\
\$ 0.00 \\
\$ 81.00 \\
\$ 156.00\end{array}$ & $\begin{array}{r}\$ 568.32 \\
\$ 855.18 \\
\$ 294.96 \\
\$ 284.16 \\
\$ 867.06 \\
2,869.68\end{array}$ & $\begin{array}{r}\$ 1,080.32 \\
\$ 1,638.18 \\
\$ 610.96 \\
\$ 540.16 \\
\$ 1,716.06 \\
\$ 5,585.68\end{array}$ \\
\hline 1.3 .1 .3 & $\begin{array}{l}\text { Stack Modifications } \\
\text { Install new stack } \\
\text { Total WBS 1.3.1.3 }\end{array}$ & $1 \mathrm{LS}$ & $\frac{32}{32}$ & $\frac{\$ 1,024.00}{\$ 1,024.00}$ & $\frac{\$ 0.00}{\$ 0.00}$ & $\frac{\$ 1,136.64}{\$ 1,136.64}$ & $\frac{\$ 2,160.64}{\$ 2,160.64}$ \\
\hline 1.3 .1 .4 & $\begin{array}{l}\text { Equipment/Platform } \\
\text { Installation } \\
\text { Install Work Platform } \\
\text { Install Stack Monitor } \\
\text { Install Stack Instrumentation } \\
\text { Install Tubing - } 1 / 2304 \mathrm{~L} \\
\text { Total WBS 1.3.1.4 }\end{array}$ & $\begin{array}{l}1 \mathrm{LS} \\
1 \mathrm{LS} \\
1 \mathrm{LS} \\
34 \mathrm{LF}\end{array}$ & $\begin{array}{l}64 \\
80 \\
16 \\
16 \\
176\end{array}$ & $\begin{array}{r}\$ 2,048.00 \\
\$ 2,560.00 \\
\$ 512.00 \\
\$ 512.00 \\
\$ 5,632.00\end{array}$ & $\begin{array}{r}\$ 1,000.00 \\
\$ 1,000.00 \\
\$ 0.00 \\
\$ 116.00 \\
\$ 2,116.00\end{array}$ & $\begin{array}{r}\$ 2,453.28 \\
\$ 3,021.60 \\
\$ 568.32 \\
\$ 589.20 \\
\$ 6,632.40\end{array}$ & $\begin{array}{r}\$ 5,501.28 \\
\$ 6,581.60 \\
\$ 1,080.32 \\
\$ 1,217.20 \\
\$ 14,380.40\end{array}$ \\
\hline 1.3 .1 .5 & $\begin{array}{l}\text { Electrical } \\
\text { 3/4" RGS Conduit } \\
3 \mathrm{C}, 10 \text { AWG, THHN } \\
30 \mathrm{~A}, 1 \text { pole, breaker } \\
\text { Stack Monitor Terminations } \\
\text { Reconfigure CASS } \\
\text { Remove existing alarms } \\
\text { Total WBS } 1.3 .1 .5\end{array}$ & $\begin{array}{l}15 \mathrm{LF} \\
25 \mathrm{LF} \\
1 \text { ea } \\
1 \mathrm{LS} \\
1 \mathrm{LS} \\
1 \mathrm{LS}\end{array}$ & $\begin{array}{c}16 \\
8 \\
8 \\
16 \\
8 \\
32 \\
88\end{array}$ & $\begin{array}{r}\$ 512.00 \\
\$ 256.00 \\
\$ 256.00 \\
\$ 512.00 \\
\$ 584.00 \\
\$ 1,024.00 \\
\$ 3,144.00\end{array}$ & $\begin{array}{r}\$ 30.00 \\
\$ 6.00 \\
\$ 16.00 \\
\$ 0.00 \\
\$ 0.00 \\
\$ 0.00 \\
\$ 52.00\end{array}$ & $\begin{array}{r}\$ 573.72 \\
\$ 285.24 \\
\$ 287.04 \\
\$ 568.32 \\
\$ 648.24 \\
\$ 1,136.64 \\
\$ 3,499.20\end{array}$ & $\begin{array}{r}\$ 1,115.72 \\
\$ 547.24 \\
\$ 559.04 \\
\$ 1,080.32 \\
\$ 1,232.24 \\
\$ 2,160.64 \\
\$ 6,695.20\end{array}$ \\
\hline 1.3 .1 .6 & \begin{tabular}{|l|} 
Waste Disposal \\
Tubing and Stack - LLW \\
Survey Cabinet/Equipment \\
Dispose of Cabinet/Equip. \\
Dispose of clean const. matls \\
Excavation dirt - LLW \\
Dispose of LLW const. matls \\
\end{tabular} & $\begin{array}{l}27 \mathrm{CF} \\
1 \mathrm{LS} \\
2 \mathrm{CY} \\
0.4 \mathrm{CY} \\
1 \mathrm{CY} \\
5 \mathrm{CF}\end{array}$ & $\begin{array}{l}8 \\
8 \\
4 \\
4 \\
4 \\
4\end{array}$ & $\begin{array}{l}\$ 256.00 \\
\$ 256.00 \\
\$ 128.00 \\
\$ 128.00 \\
\$ 128.00 \\
\$ 128.00\end{array}$ & $\begin{array}{r}\$ 972.27 \\
\$ 0.00 \\
\$ 70.00 \\
\$ 14.00 \\
\$ 972.27 \\
\$ 180.05 \\
\end{array}$ & $\begin{array}{l}\$ 459.17 \\
\$ 284.16 \\
\$ 154.68 \\
\$ 144.60 \\
\$ 317.09 \\
\$ 174.49\end{array}$ & $\begin{array}{r}\$ 1,687.44 \\
\$ 540.16 \\
\$ 352.68 \\
\$ 286.60 \\
\$ 1,417.36 \\
\$ 482.54\end{array}$ \\
\hline & Total WBS 1.3.1.6 & & 32 & $\$ 1,024.00$ & $\$ 2,208.59$ & $\$ 1,534.19$ & $\$ 4,766.78$ \\
\hline 1.3 .1 .7 & \begin{tabular}{|l|} 
Conduct ATP \\
Total WBS 1.3.1.7 \\
\end{tabular} & $1 \mathrm{LS}$ & 64 & $\begin{array}{l}\$ 2,048.00 \\
\$ 2,048.00 \\
\end{array}$ & $\begin{array}{r}\$ 0.00 \\
\$ 0.00\end{array}$ & $\begin{array}{l}\$ 2,273.28 \\
\$ 2,273.28 \\
\end{array}$ & $\begin{array}{l}\$ 4,321.28 \\
\$ 4,321.28 \\
\end{array}$ \\
\hline & \begin{tabular}{|l|} 
SUB TOTAL 1.3 .1 \\
$35 \%$ adder for SWP Work \\
SUB TOTAL 1.3.1 \\
$30 \%$ adder for Const. Suppor
\end{tabular} & & $\begin{array}{l}528 \\
185 \\
713 \\
214\end{array}$ & $\begin{array}{r}\$ 17,224.00 \\
\$ 6,028.40 \\
\$ 23,252.40 \\
\$ 6,975.72\end{array}$ & $\begin{array}{r}\$ 4,532.59 \\
\$ 0.00 \\
\$ 4,532.59 \\
\$ 0.00\end{array}$ & $\begin{array}{r}\$ 19,934.51 \\
\$ 0.00 \\
\$ 19,934.51 \\
\$ 0.00\end{array}$ & $\begin{array}{r}\$ 41,691.10 \\
\$ 6,028.40 \\
\$ 47,719.50 \\
\$ 6,975.72\end{array}$ \\
\hline & Total 1.3.1 & & 927 & $\$ 30,228.12$ & $\$ 4,532.59$ & $\$ 19,934.51$ & $\$ 54,695.22$ \\
\hline
\end{tabular}




\section{Project $W-420$}

Stack Monitoring System Upgrades

Estimate Details for Construction Activities (296-B-28)

\begin{tabular}{|c|c|c|c|c|c|c|c|}
\hline WBS & Activity & Quantity & $\begin{array}{c}\text { Man } \\
\text { Hours } \\
\end{array}$ & Labor & $\begin{array}{l}\text { Equipment/ } \\
\text { Material }\end{array}$ & $\begin{array}{c}\text { Overhead } \\
\text { Profit }\end{array}$ & Total Cost \\
\hline \multirow[t]{5}{*}{1.3 .2 .1} & Site Work/Demolition & & & & & & \\
\hline & Deenergize and tagout equip. & $1 \mathrm{LS}$ & 8 & $\$ 256.00$ & $\$ 0.00$ & $\$ 284.16$ & $\$ 540.16$ \\
\hline & Remove Existing Monitor & $1 \mathrm{LS}$ & 24 & $\$ 768.00$ & $\$ 0.00$ & $\$ 852.48$ & $\$ 1,620.48$ \\
\hline & Remove Existing Stack & $1 \mathrm{LS}$ & 24 & $\$ 768.00$ & $\$ 0.00$ & $\$ 852.48$ & $\$ 1,620.48$ \\
\hline & Total WBS 1.3.2.1 & & 56 & $\$ 1,792.00$ & $\$ 0.00$ & $\$ 1,989.12$ & $\$ 3,781.12$ \\
\hline \multirow{9}{*}{1.3 .2 .2} & Support Pads - 3'6"x & & & & & & \\
\hline & $3 \times 7^{\prime}$ & & & & & & \\
\hline & Excavation & $2 \mathrm{CY}$ & 24 & $\$ 768.00$ & $\$ 0.00$ & $\$ 852.48$ & $\$ 1,620.48$ \\
\hline & Form Work & $40 \mathrm{LF}$ & 40 & $\$ 1,280.00$ & $\$ 30.00$ & $\$ 1,426.20$ & $\$ 2,736.20$ \\
\hline & Pour cement & $2 \mathrm{CY}$ & 16 & $\$ 512.00$ & $\$ 120.00$ & $\$ 589.92$ & $\$ 1,221.92$ \\
\hline & Finish Work & $44 \mathrm{SF}$ & 16 & $\$ 512.00$ & $\$ 0.00$ & $\$ 568.32$ & $\$ 1,080.32$ \\
\hline & Hilti-Bolt Embeds & $1 \mathrm{LS}$ & 24 & $\$ 768.00$ & $\$ 81.00$ & $\$ 867.06$ & $\$ 1,716.06$ \\
\hline & Move Existing Fence $3^{\prime}$ & $1 \mathrm{LS}$ & 32 & $\$ 1,024,00$ & $\$ 30.00$ & $\$ 1,142.04$ & $\$ 2,196.04$ \\
\hline & Total WBS 1.3.2.2 & & 152 & $\$ 4,864.00$ & $\$ 261.00$ & $\$ 5,446.02$ & $\$ 10,571.02$ \\
\hline \multirow[t]{3}{*}{1.3 .2 .3} & Stack Modifications & & & & & & \\
\hline & install & $1 \mathrm{LS}$ & $\frac{32}{3 n}$ & $\$ 1,024.00$ & $\$ 0.00$ & $\$ 1,136.64$ & $\$ 2,160.64$ \\
\hline & Total WBS 1.3 .2 .3 & & 32 & $\$ 1,024.00$ & $\$ 0.00$ & .64 & \\
\hline \multirow[t]{6}{*}{1.3 .2 .4} & Equipment/Platform & & & & & & \\
\hline & Install Work Platform & $1 \mathrm{LS}$ & 64 & $\$ 2,048.00$ & $\$ 1,000.00$ & $\$ 2,453.28$ & $\$ 5,501.28$ \\
\hline & Install Stack Monitor & $1 \mathrm{LS}$ & 80 & $\$ 2,560.00$ & $\$ 1,000.00$ & $\$ 3,021.60$ & $\$ 6,581,60$ \\
\hline & Install Stack Instrumentation & $1 \mathrm{LS}$ & 8 & $\$ 256.00$ & $\$ 0.00$ & $\$ 284.16$ & $\$ 540.16$ \\
\hline & Install Tubing $-1 / 2304 \mathrm{~L}$ & $40 \mathrm{LF}$ & 8 & $\$ 256.00$ & $\$ 136.00$ & $\$ 308.64$ & $\$ 700.64$ \\
\hline & Total WBS 1.3.2.4 & & 160 & $\$ 5,120.00$ & $\$ 2,136.00$ & $\$ 6,067.68$ & $\$ 13,323.68$ \\
\hline \multirow[t]{8}{*}{1.3 .2 .5} & Electrical & & & & & & \\
\hline & 3/4" RGS Conduit & $15 \mathrm{LF}$ & 16 & $\$ 512.00$ & $\$ 30.00$ & $\$ 573.72$ & $\$ 1,115.72$ \\
\hline & WG, THHN & $15 \mathrm{LF}$ & 8 & $\$ 256.00$ & $\$ 4.00$ & $\$ 284.88$ & $\$ 544.88$ \\
\hline & $30 \mathrm{~A}, 1$ pole, breaker & $1 \mathrm{ea}$ & 8 & $\$ 256.00$ & $\$ 16.00$ & $\$ 287.04$ & $\$ 559.04$ \\
\hline & Stack Monitor Terminations & $1 \mathrm{LS}$ & 16 & $\$ 512.00$ & $\$ 0.00$ & $\$ 568.32$ & $\$ 1,080.32$ \\
\hline & Reconfigure CASS & $1 \mathrm{LS}$ & 8 & $\$ 584.00$ & $\$ 0.00$ & $\$ 648.24$ & $\$ 1,232.24$ \\
\hline & Remove existing alarms & $1 \mathrm{LS}$ & 32 & $\$ 1,024.00$ & $\$ 0.00$ & $\$ 1,136.64$ & $\$ 2,160.64$ \\
\hline & Total WBS 1.3.2.5 & & 88 & $\$ 3,144.00$ & $\$ 50.00$ & $\$ 3,498.84$ & $\$ 6,692.84$ \\
\hline \multirow[t]{8}{*}{1.3 .2 .6} & Waste & & & & & & \\
\hline & Tubing and Stack - 1 & $40 \mathrm{CF}$ & 8 & $\$ 256.00$ & $\$ 1,440.40$ & $\$ 543.43$ & $\$ 2,239.83$ \\
\hline & Survey Cabinet/Equipment & $1 \mathrm{LS}$ & 8 & $\$ 256.00$ & $\$ 0.00$ & $\$ 284.16$ & $\$ 540.16$ \\
\hline & Dispose of Cabinet/Equip. & $2 \mathrm{CY}$ & 4 & $\$ 128.00$ & $\$ 70.00$ & $\$ 154.68$ & $\$ 352.68$ \\
\hline & Dispose of clean const. matls & $0.4 \mathrm{CY}$ & 4 & $\$ 128.00$ & $\$ 14.00$ & $\$ 144.60$ & $\$ 286.60$ \\
\hline & Excavation dirt - LLW & $1 \mathrm{Cr}$ & 4 & $\$ 128.00$ & $\$ 972.27$ & $\$ 317.09$ & $\$ 1,417.36$ \\
\hline & Dispose of LLW const. matls & $5 \mathrm{CF}$ & 4 & $\$ 128.00$ & $\$ 180.05$ & $\$ 174.49$ & $\$ 482.54$ \\
\hline & Total WBS 1.3.2.6 & & 32 & $\$ 1,024.00$ & $\$ 2,676.72$ & $\$ 1,618.45$ & $\$ 5,319.17$ \\
\hline \multirow{2}{*}{1.3 .2 .7} & Condu & TLS & 64 & $\$ 2,048.00$ & $\$ 0.00$ & $\$ 2,273.28$ & $\$ 4,321.28$ \\
\hline & Total WBS 1.3.2.7 & & 64 & $\$ 2,048.00$ & $\$ 0.00$ & $\$ 2,273.28$ & $\$ 4,321.28$ \\
\hline & SUB TOTAL 1.3 .2 & & 584 & $\$ 19,016.00$ & $\$ 5,123.72$ & $\$ 22,030.03$ & $\$ 46,169.75$ \\
\hline & $30^{\circ}$ & & 175 & $\$ 5,7$ & $\$ 0.00$ & 0 & 80 \\
\hline & Total 1.3.2 & & 759 & $\$ 24,720.80$ & $\$ 5,123.72$ & $\$ 22,030.03$ & $\$ 51,874.55$ \\
\hline
\end{tabular}




\section{Project W-420}

Stack Monitoring System Upgrades

Estimate Details for Construction Activities (296-S-22)

\begin{tabular}{|c|c|c|c|c|c|c|c|}
\hline WBS & Activity & Quantity & $\begin{array}{l}\text { Man } \\
\text { Hours }\end{array}$ & Labor & $\begin{array}{c}\text { Equipment } \\
\text { Material }\end{array}$ & $\begin{array}{l}\text { Overhead } \\
\text { Profit }\end{array}$ & Total Cost \\
\hline \multirow[t]{2}{*}{1.3 .3 .1} & $\begin{array}{l}\text { Site Work/Demolition } \\
\text { Deenergize and tagout equip. } \\
\text { Remove Existing Monitor } \\
\text { Remove Existing Stack }\end{array}$ & $\begin{array}{l}1 \text { LS } \\
1 \text { LS } \\
1 \text { LS }\end{array}$ & $\begin{array}{c}8 \\
24 \\
24\end{array}$ & $\begin{array}{l}\$ 256.00 \\
\$ 768.00 \\
\$ 768.00\end{array}$ & $\begin{array}{l}\$ 0.00 \\
\$ 0.00 \\
\$ 0.00\end{array}$ & $\begin{array}{l}\$ 284.16 \\
\$ 852.48 \\
\$ 852.48\end{array}$ & $\begin{array}{r}\$ 540.16 \\
\$ 1,620.48 \\
\$ 1,620.48\end{array}$ \\
\hline & Total WBS 1.3.3.1 & & 56 & $\$ 1,792.00$ & $\$ 0.00$ & $\$ 1,989.12$ & $\$ 3,781.12$ \\
\hline 1.3 .3 .2 & $\begin{array}{l}\text { Support Pad - } 5 \times 7^{\prime} \\
\text { Excavation } \\
\text { Form Work } \\
\text { Pour cement } \\
\text { Finish Work } \\
\text { Hilti-Bolt Embeds } \\
\end{array}$ & $\begin{array}{c}1 \mathrm{CY} \\
24 \mathrm{LF} \\
1 \mathrm{CY} \\
35 \mathrm{SF} \\
1 \mathrm{LS}\end{array}$ & $\begin{array}{c}16 \\
24 \\
8 \\
8 \\
24 \\
80\end{array}$ & $\begin{array}{r}\$ 512.00 \\
\$ 768.00 \\
\$ 256.00 \\
\$ 256.00 \\
\$ 768.00 \\
\$ 256000\end{array}$ & $\begin{array}{r}\$ 0.00 \\
\$ 30.00 \\
\$ 60.00 \\
\$ 0.00 \\
\$ 81.00 \\
\$ 171.00\end{array}$ & $\begin{array}{l}\$ 568.32 \\
\$ 857.88 \\
\$ 294.96 \\
\$ 284.16 \\
\$ 867.06 \\
287238\end{array}$ & $\begin{array}{r}\$ 1,080.32 \\
\$ 1,655.88 \\
\$ 510.96 \\
\$ 540.16 \\
\$ 1,716.06 \\
\$ 560338\end{array}$ \\
\hline 1.3 .3 .3 & $\begin{array}{l}\text { Stack Modifications } \\
\text { Install new stack } \\
\text { Total WBS } 1.3 .3 .3\end{array}$ & $1 \mathrm{LS}$ & $\frac{32}{32}$ & $\frac{\$ 1,024.00}{\$ 1,02400}$ & $\frac{\$ 0.00}{\$ 0.00}$ & $\frac{\$ 1,136.64}{\$ 1,136.64}$ & $\frac{\$ 2,160.64}{\$ 216064}$ \\
\hline 1.3 .3 .4 & $\begin{array}{l}\text { Equipment/Platform } \\
\text { Installation } \\
\text { Install Work Platform } \\
\text { Install Stack Monitor } \\
\text { Install Stack Instrumentation } \\
\text { Install Tubing - } 1 / 2 \text { 304L } \\
\text { Total WBS } 1.3 .3 .4\end{array}$ & $\begin{array}{l}1 \text { LS } \\
1 \text { LS } \\
1 \text { LS } \\
40 \text { LF }\end{array}$ & $\begin{array}{c}64 \\
80 \\
8 \\
8 \\
160\end{array}$ & $\begin{array}{r}\$ 2,048.00 \\
\$ 2,560.00 \\
\$ 256.00 \\
\$ 256.00 \\
\$ 5,120.00\end{array}$ & $\begin{array}{r}\$ 1,000.00 \\
\$ 1,000.00 \\
\$ 0.00 \\
\$ 136.00 \\
\$ 2.136 .00\end{array}$ & $\begin{array}{r}\$ 2,453.28 \\
\$ 3,021.60 \\
\$ 284.16 \\
\$ 308.64 \\
\$ 6.067 .68\end{array}$ & $\begin{array}{r}\$ 5,501.28 \\
\$ 6,581.60 \\
\$ 540.16 \\
\$ 700.64 \\
\$ 1332368\end{array}$ \\
\hline 1.3 .3 .5 & $\begin{array}{l}\text { Electrical } \\
3 / 4 " \text { RGS Conduit } \\
3 \mathrm{C}, 10 \mathrm{AWG}, \text { THHN } \\
30 \mathrm{~A}, 1 \text { pole, breaker } \\
\text { Stack monitor terminations } \\
\text { Reconfigure CASS } \\
\text { Remove existing alarms } \\
\text { Total WBS } 1.3 .3 .5\end{array}$ & $\begin{array}{l}15 \mathrm{LF} \\
15 \mathrm{LF} \\
1 \mathrm{ea} \\
1 \mathrm{LS} \\
1 \mathrm{LS} \\
1 \mathrm{LS}\end{array}$ & $\begin{array}{c}16 \\
8 \\
8 \\
16 \\
8 \\
32 \\
88\end{array}$ & $\begin{array}{r}\$ 512.00 \\
\$ 256.00 \\
\$ 256.00 \\
\$ 512.00 \\
\$ 584.00 \\
\$ 1,024.00 \\
\$ 3,144.00\end{array}$ & $\begin{array}{r}\$ 30.00 \\
\$ 4.00 \\
\$ 16.00 \\
\$ 0.00 \\
\$ 0.00 \\
\$ 0.00 \\
\$ 50.00\end{array}$ & $\begin{array}{r}\$ 573.72 \\
\$ 284.88 \\
\$ 287.04 \\
\$ 568.32 \\
\$ 648.24 \\
\$ 1,136.64 \\
\$ 3,498.84\end{array}$ & $\begin{array}{r}\$ 1,115.72 \\
\$ 544.88 \\
\$ 559.04 \\
\$ 1,080.32 \\
\$ 1,232.24 \\
\$ 2,160.64 \\
\$ 6,692.84\end{array}$ \\
\hline \multirow[t]{2}{*}{1.3 .3 .6} & $\begin{array}{l}\text { Waste Disposal } \\
\text { Tubing and Stack - LLW } \\
\text { Survey Cabinet/Equipment } \\
\text { Dispose of Cabinet/Equip. } \\
\text { Dispose of clean const. matls } \\
\text { Excavation dirt - LLW } \\
\text { Dispose of LLW const. matls }\end{array}$ & $\begin{array}{l}40 \mathrm{CF} \\
1 \mathrm{LS} \\
2 \mathrm{CY} \\
0.4 \mathrm{CY} \\
1 \mathrm{CY} \\
5 \mathrm{CF}\end{array}$ & $\begin{array}{l}8 \\
8 \\
4 \\
4 \\
4 \\
4\end{array}$ & $\begin{array}{l}\$ 256.00 \\
\$ 256.00 \\
\$ 128.00 \\
\$ 128.00 \\
\$ 128.00 \\
\$ 128.00\end{array}$ & $\begin{array}{r}\$ 1,440.40 \\
\$ 0.00 \\
\$ 70.00 \\
\$ 14.00 \\
\$ 972.27 \\
\$ 180.05\end{array}$ & $\begin{array}{l}\$ 543.43 \\
\$ 284.16 \\
\$ 154.68 \\
\$ 144.60 \\
\$ 317.09 \\
\$ 174.49\end{array}$ & $\begin{array}{r}\$ 2,239.83 \\
\$ 540.16 \\
\$ 352.68 \\
\$ 286.60 \\
\$ 1,417.36 \\
\$ 482.54 \\
\end{array}$ \\
\hline & Total WBS 1.3.3.6 & & 32 & $\$ 1,024.00$ & $\$ 2,676.72$ & $\$ 1,618.45$ & $\$ 5,319.17$ \\
\hline \multirow[t]{3}{*}{1.3 .3 .7} & \begin{tabular}{|l} 
Conduct ATP \\
Total WBS 1.3.3.7
\end{tabular} & $1 \mathrm{LS}$ & $\frac{64}{64}$ & $\begin{array}{l}\$ 2,048.00 \\
\$ 2,048.00\end{array}$ & $\begin{array}{l}\$ 0.00 \\
\$ 0.00\end{array}$ & $\begin{array}{l}\$ 2,273.28 \\
\$ 2,273.28\end{array}$ & $\begin{array}{l}\$ 4,321.28 \\
\$ 4,321.28\end{array}$ \\
\hline & $\begin{array}{l}\text { SUB TOTAL } 1.3 .3 \\
30 \% \text { adder for Const. Suppor }\end{array}$ & & $\begin{array}{l}512 \\
154\end{array}$ & $\begin{array}{r}\$ 16,712.00 \\
\$ 5,013.60 \\
\end{array}$ & $\begin{array}{r}\$ 5,033.72 \\
\$ 0.00\end{array}$ & $\begin{array}{r}\$ 19,456.39 \\
\$ 0.00 \\
\end{array}$ & $\begin{array}{r}\$ 41,202.11 \\
\$ 5,013.60\end{array}$ \\
\hline & Total 1.3.3 & & 666 & $\$ 21,725.60$ & $\$ 5,033.72$ & $\$ 19,456.39$ & $\$ 46,215.71$ \\
\hline
\end{tabular}




\section{Project $\mathbf{W}-420$}

\section{Stack Monitoring System Upgrades}

Estimate Details for Construction Activities (296-T-18)

\begin{tabular}{|c|c|c|c|c|c|c|c|}
\hline WBS & Activity & Quantity & $\begin{array}{l}\text { Man } \\
\text { Hours }\end{array}$ & Labor & $\begin{array}{c}\text { Equipment/ } \\
\text { Material }\end{array}$ & $\begin{array}{l}\text { Overhead } \\
\text { Profit }\end{array}$ & Total Cost \\
\hline 1.3 .4 .1 & \begin{tabular}{l|} 
Site Work/Demolition \\
Deenergize and tagout equip. \\
Remove Existing Monitor \\
Remove Existing Stack \\
Total WBS 1.3.4.1
\end{tabular} & $\begin{array}{l}1 \text { LS } \\
1 \text { LS } \\
1 \text { LS }\end{array}$ & $\begin{array}{c}8 \\
24 \\
24 \\
56\end{array}$ & $\begin{array}{r}\$ 256.00 \\
\$ 768.00 \\
\$ 768.00 \\
\$ 1,792.00\end{array}$ & $\begin{array}{l}\$ 0.00 \\
\$ 0.00 \\
\$ 0.00 \\
\$ 0.00\end{array}$ & $\begin{array}{r}\$ 284.16 \\
\$ 852.48 \\
\$ 852.48 \\
\$ 1,989.12\end{array}$ & $\begin{array}{r}\$ 540.16 \\
\$ 1,620.48 \\
\$ 1,620.48 \\
\$ 3,781.12\end{array}$ \\
\hline 1.3 .4 .2 & \begin{tabular}{|l|} 
Support Pads $-3^{\prime} 6^{\prime \prime} \times 6^{\prime} 6^{\prime \prime}$ and \\
$3^{\prime} \times 7^{\prime}$ \\
Excavation \\
Form Work \\
Pour cement \\
Finish Work \\
Hilti-Bolt Embeds \\
Total WBS 1.3.4.2
\end{tabular} & $\begin{array}{l}2 \mathrm{CY} \\
40 \mathrm{LF} \\
2 \mathrm{CY} \\
45 \mathrm{SF} \\
1 \mathrm{LS}\end{array}$ & $\begin{array}{l}24 \\
40 \\
16 \\
16 \\
24 \\
120\end{array}$ & $\begin{array}{r}\$ 768.00 \\
\$ 1,280.00 \\
\$ 512.00 \\
\$ 512.00 \\
\$ 768.00 \\
\$ 3,840.00\end{array}$ & $\begin{array}{r}\$ 0.00 \\
\$ 30.00 \\
\$ 120.00 \\
\$ 0.00 \\
\$ 81.00 \\
\$ 231.00\end{array}$ & $\begin{array}{r}\$ 852.48 \\
\$ 1,426.20 \\
\$ 589.92 \\
\$ 568.32 \\
\$ 867.06 \\
\$ 4,303.98\end{array}$ & $\begin{array}{l}\$ 1,620.48 \\
\$ 2,736.20 \\
\$ 1,221.92 \\
\$ 1,080.32 \\
\$ 1,716.06 \\
\$ 8,374.98\end{array}$ \\
\hline 1.3 .4 .3 & $\begin{array}{l}\text { Stack Modifications } \\
\text { Install new stack } \\
\text { Total WBS 1.3.4.3 }\end{array}$ & $1 \mathrm{LS}$ & $\frac{32}{32}$ & $\begin{array}{l}\$ 1,024.00 \\
\$ 1,024.00\end{array}$ & $\frac{\$ 0.00}{\$ 0.00}$ & $\begin{array}{l}\$ 1,136.64 \\
1,136.64\end{array}$ & $\begin{array}{l}\$ 2,160.64 \\
\$ 2,160.64\end{array}$ \\
\hline 1.3 .4 .4 & $\begin{array}{l}\text { Equipment/Platform } \\
\text { Installation } \\
\text { Install Work Platform } \\
\text { Install Stack Monitor } \\
\text { Install Stack Instrumentation } \\
\text { Install Tubing }-1 / 2304 \mathrm{~L} \\
\text { Total WBS } 1.3 .4 .4\end{array}$ & $\begin{array}{l}1 \text { LS } \\
1 \text { LS } \\
1 \text { LS } \\
40 \mathrm{LF}\end{array}$ & $\begin{array}{c}64 \\
80 \\
8 \\
8 \\
160\end{array}$ & $\begin{array}{r}\$ 2,048.00 \\
\$ 2,560.00 \\
\$ 256.00 \\
\$ 256.00 \\
\$ 5,120.00\end{array}$ & $\begin{array}{r}\$ 1,000.00 \\
\$ 1,000.00 \\
\$ 0.00 \\
\$ 136.00 \\
\$ 2,136.00\end{array}$ & $\begin{array}{r}\$ 2,453.28 \\
\$ 3,021.60 \\
\$ 284.16 \\
\$ 308.64 \\
\$ 6,067.68\end{array}$ & $\begin{array}{r}\$ 5,501.28 \\
\$ 6,581.60 \\
\$ 540.16 \\
\$ 700.64 \\
13,323.68\end{array}$ \\
\hline 1.3 .4 .5 & $\begin{array}{l}\text { Electrical } \\
\text { 3/4" RGS Conduit } \\
3 \mathrm{C}, 10 \text { AWG, THHN } \\
30 \mathrm{~A}, 1 \text { pole, breaker } \\
\text { Stack monitor terminations } \\
\text { Reconfigure CASS } \\
\text { Remove existing alarms } \\
\text { TotalWBS } 13.45\end{array}$ & $\begin{array}{l}15 \mathrm{LF} \\
15 \mathrm{LF} \\
1 \text { ea } \\
1 \mathrm{LS} \\
1 \mathrm{LS} \\
1 \mathrm{LS}\end{array}$ & $\begin{array}{c}16 \\
8 \\
8 \\
16 \\
8 \\
32 \\
88\end{array}$ & $\begin{array}{r}\$ 512.00 \\
\$ 256.00 \\
\$ 256.00 \\
\$ 512.00 \\
\$ 584.00 \\
\$ 1,024.00 \\
\$ 3144.00\end{array}$ & $\begin{array}{r}\$ 30.00 \\
\$ 4.00 \\
\$ 16.00 \\
\$ 0.00 \\
\$ 0.00 \\
\$ 0.00 \\
50.00\end{array}$ & $\begin{array}{r}\$ 573.72 \\
\$ 284.88 \\
\$ 287.04 \\
\$ 568.32 \\
\$ 648.24 \\
\$ 1,136.64 \\
\$ 3.498 .84\end{array}$ & $\begin{array}{r}\$ 1,115.72 \\
\$ 544.88 \\
\$ 559.04 \\
\$ 1,080.32 \\
\$ 1,232.24 \\
\$ 2,160.64 \\
\$ 669284\end{array}$ \\
\hline 1.3 .4 .6 & $\begin{array}{l}\text { Waste Disposal } \\
\text { Tubing and Stack - LLW } \\
\text { Survey Cabinet/Equipment } \\
\text { Dispose of Cabinet/Equip. } \\
\text { Dispose of clean const. matls } \\
\text { Excavation dirt - LLW } \\
\text { Dispose of LLW const. matls }\end{array}$ & $\begin{array}{l}40 \mathrm{CF} \\
1 \mathrm{LS} \\
2 \mathrm{CY} \\
0.4 \mathrm{CY} \\
1 \mathrm{CY} \\
5 \mathrm{CF} \\
\end{array}$ & $\begin{array}{l}8 \\
8 \\
4 \\
4 \\
4 \\
4\end{array}$ & $\begin{array}{l}\$ 256.00 \\
\$ 256.00 \\
\$ 128.00 \\
\$ 128.00 \\
\$ 128.00 \\
\$ 128.00 \\
\end{array}$ & $\begin{array}{r}\$ 1,440.40 \\
\$ 0.00 \\
\$ 70.00 \\
\$ 14.00 \\
\$ 972.27 \\
\$ 180.05 \\
\end{array}$ & $\begin{array}{l}\$ 543.43 \\
\$ 284.16 \\
\$ 154.68 \\
\$ 144.60 \\
\$ 317.09 \\
\$ 174.49 \\
\end{array}$ & $\begin{array}{r}\$ 2,239.83 \\
\$ 540.16 \\
\$ 352.68 \\
\$ 286.60 \\
\$ 1,417.36 \\
\$ 482.54 \\
\end{array}$ \\
\hline & Total WBS 1.3.4.6 & & 32 & $\$ 1,024.00$ & $\$ 2,676.72$ & $\$ 1,618.45$ & $\$ 5,319.17$ \\
\hline 1.3 .4 .7 & \begin{tabular}{|l} 
Conduct ATP \\
Total WBS 1.3.4.7 \\
\end{tabular} & $1 \mathrm{LS}$ & $\begin{array}{l}64 \\
64 \\
\end{array}$ & $\begin{array}{l}\$ 2,048.00 \\
\$ 2,048.00\end{array}$ & $\begin{array}{l}\$ 0.00 \\
\$ 0.00\end{array}$ & $\begin{array}{l}\$ 2,273.28 \\
\$ 2,273.28\end{array}$ & $\begin{array}{l}\$ 4,321.28 \\
\$ 4,321.28\end{array}$ \\
\hline & $\begin{array}{l}\text { SUB TOTAL } 1.3 .4 \\
35 \% \text { Adder for SWP work } \\
\text { SUB TOTAL } 1.3 .4 \\
30 \% \text { adder for Const. Suppor }\end{array}$ & & $\begin{array}{l}552 \\
193 \\
745 \\
224\end{array}$ & $\begin{array}{r}\$ 17,992.00 \\
\$ 6,297.20 \\
\$ 24,289.20 \\
\$ 7,286.76 \\
\end{array}$ & $\begin{array}{r}\$ 5,093.72 \\
\$ 0.00 \\
\$ 5,093.72 \\
\$ 0.00\end{array}$ & $\begin{array}{r}\$ 20,887.99 \\
\$ 0.00 \\
\$ 20,887.99 \\
\$ 0.00\end{array}$ & $\begin{array}{r}\$ 43,973.71 \\
\$ 6,297.20 \\
\$ 50,270.91 \\
\$ 7,286.76 \\
\end{array}$ \\
\hline & Total 1.3.4 & & 969 & $\$ 31,575.96$ & $\$ 5,093.72$ & $\$ 20,887.99$ & $\$ 57,557.67$ \\
\hline
\end{tabular}


FNF-SD-W420-CDR-001, Rev. 0

\section{Project $W-420$}

Stack Monitoring System Upgrades

Estimate Details for Construction Activities (296-C-05)

\begin{tabular}{|c|c|c|c|c|c|c|c|}
\hline WBS & Activity & Quantity & $\begin{array}{c}\text { Man } \\
\text { Hours } \\
\end{array}$ & Labor & $\begin{array}{l}\text { Equipment/ } \\
\text { Material }\end{array}$ & $\begin{array}{c}\text { Overhead } \\
\text { Profit }\end{array}$ & Total Cost \\
\hline \multirow[t]{4}{*}{1.3 .5 .1} & Site Work/Demolition & & & & & & \\
\hline & Deenergize and tagout equip. & $1 \mathrm{LS}$ & 8 & $\$ 256.00$ & $\$ 0.00$ & $\$ 284.16$ & $\$ 540.16$ \\
\hline & Remove Existing Monitor & $1 \mathrm{LS}$ & 24 & $\$ 768.00$ & $\$ 0.00$ & $\$ 852.48$ & $\$ 1,620.48$ \\
\hline & Total WBS 1.3.5.1 & & 32 & $\$ 1,024.00$ & $\$ 0.00$ & $\$ 1,136.64$ & $\$ 2,160.64$ \\
\hline \multirow[t]{7}{*}{1.3 .5 .2} & Support Pad - 7×12 & & & & & & \\
\hline & Excavation & $2 \mathrm{Cr}$ & 48 & $\$ 1,536.00$ & $\$ 0.00$ & $\$ 1,704.96$ & $\$ 3,240.96$ \\
\hline & Form Work & $38 \mathrm{LF}$ & 32 & $\$ 1,024.00$ & $\$ 45.00$ & $\$ 1,144.74$ & $\$ 2,213.74$ \\
\hline & Pour cement & $2 \mathrm{CY}$ & 16 & $\$ 512.00$ & $\$ 100.00$ & $\$ 586.32$ & $\$ 1,198.32$ \\
\hline & Finish Work & $84 \mathrm{SF}$ & 16 & $\$ 512.00$ & $\$ 0.00$ & $\$ 568.32$ & $\$ 1,080.32$ \\
\hline & Hilti-Bolt Embeds & $1 \mathrm{LS}$ & 24 & $\$ 768.00$ & $\$ 81.00$ & $\$ 867.06$ & $\$ 1,716.06$ \\
\hline & Total WBS 1.3.5.2 & & 136 & $\$ 4,352.00$ & $\$ 226.00$ & $\$ 4,871.40$ & $\$ 9,449.40$ \\
\hline \multirow[t]{4}{*}{1.3 .5 .3} & Stack Modifications & & & & & & \\
\hline & Drill 1" holes & $1 \mathrm{LS}$ & 8 & $\$ 256.00$ & $\$ 0.00$ & $\$ 284.16$ & $\$ 540.16$ \\
\hline & Weld 1" Nipples & 6 & 24 & $\$ 768.00$ & $\$ 1,036.00$ & $\$ 1,038.96$ & $\$ 2,842.96$ \\
\hline & Total WBS 1.3.5.3 & & 32 & $\$ 1,024.00$ & $\$ 1,036.00$ & $\$ 1,323.12$ & $3,383.12$ \\
\hline \multirow[t]{6}{*}{1.3 .5 .4} & Equipment/Platform & & & & & & \\
\hline & Install Work Platform & $1 \mathrm{LS}$ & 100 & $\$ 3,200.00$ & $\$ 1,000.00$ & $\$ 3,732.00$ & $\$ 7,932.00$ \\
\hline & Install Stack Monitor & $1 \mathrm{LS}$ & 80 & $\$ 2,560.00$ & $\$ 1,000.00$ & $\$ 3,021,60$ & $\$ 6,581.60$ \\
\hline & Install Stack Instrumentation & $1 \mathrm{LS}$ & 16 & $\$ 512.00$ & $\$ 0.00$ & $\$ 568.32$ & $\$ 1,080.32$ \\
\hline & Install Tubing $-1 / 2304 \mathrm{~L}$ & $50 \mathrm{LF}$ & 16 & $\$ 512.00$ & $\$ 170.00$ & $\$ 598.92$ & $\$ 1,280.92$ \\
\hline & Total WBS 1.3.5.4 & & 212 & $\$ 6,784.00$ & $\$ 2,170.00$ & $\$ 7,920.84$ & $\$ 16,874,84$ \\
\hline \multirow[t]{8}{*}{1.3 .5 .5} & Electrical & & & & & & \\
\hline & 3/4" RGS Conduit & $15 \mathrm{LF}$ & 16 & $\$ 512.00$ & $\$ 30.00$ & $\$ 573.72$ & $\$ 1,115.72$ \\
\hline & $3 C, 10$ AWG, THHN & $15 \mathrm{LF}$ & 8 & $\$ 256.00$ & $\$ 45.00$ & $\$ 292.26$ & $\$ 593.26$ \\
\hline & $30 \mathrm{~A}, 1$ pole, Breaker & 1 ea & 8 & $\$ 256.00$ & $\$ 16.00$ & $\$ 287.04$ & $\$ 559.04$ \\
\hline & Stack Monitor Terminations & $1 \mathrm{LS}$ & 16 & $\$ 512.00$ & $\$ 0.00$ & $\$ 568.32$ & $\$ 1,080.32$ \\
\hline & Reconfigure CASS & $1 \mathrm{LS}$ & 8 & $\$ 584.00$ & $\$ 0.00$ & $\$ 648.24$ & $\$ 1,232.24$ \\
\hline & Remove existing alarms & $1 \mathrm{LS}$ & 32 & $\$ 1,024.00$ & $\$ 0.00$ & & $\$ 2,160.64$ \\
\hline & Total WBS 1.3.5.5 & & 88 & $\$ 3,144.00$ & $\$ 91.00$ & $\$ 3,506.22$ & $\$ 6,741.22$ \\
\hline \multirow[t]{8}{*}{1.3 .5 .6} & Waste Disposal & & & & & & \\
\hline & Tubing - LLW & $5 \mathrm{CF}$ & 8 & $\$ 256.00$ & $\$ 180.05$ & $\$ 316.57$ & $\$ 752.62$ \\
\hline & Survey Cabinet/Eq & 1 LS & 8 & $\$ 256.00$ & $\$ 0.00$ & & $\$ 540.16$ \\
\hline & Dispose of Cabinet/Equip. & $2 \mathrm{CY}$ & 4 & $\$ 128.00$ & $\$ 70.00$ & $\$ 154.68$ & $\$ 352.68$ \\
\hline & Dispose of clean const. matls & $0.4 \mathrm{CY}$ & 4 & $\$ 128.00$ & $\$ 14.00$ & $\$ 144.60$ & $\$ 286.60$ \\
\hline & Excavation dirt - LLW & $2 \mathrm{CY}$ & 4 & $\$ 128.00$ & $\$ 1,944.54$ & $\$ 492.10$ & $\$ 2,564.64$ \\
\hline & Dispose of LLW const. matls & $5 \mathrm{CF}$ & 4 & $\$ 128.00$ & $\$ 180.05$ & $\$ 174.49$ & $\$ 482.54$ \\
\hline & Total WBS 1.3 .5 .6 & & 32 & $\$ 1,024.00$ & $\$ 2,388.64$ & $\$ 1,566.60$ & $\$ 4,979.24$ \\
\hline \multirow[t]{2}{*}{1.3 .5 .7} & Conduct ATP & $1 \mathrm{LS}$ & 64 & $\$ 2,048.00$ & $\$ 0.00$ & $\$ 2,273.28$ & $\$ 4,321.28$ \\
\hline & Total WBS 1.3.5.7 & & 64 & $\$ 2,048.00$ & $\$ 0.00$ & $\$ 2,273.28$ & $\$ 4,321.28$ \\
\hline & SUB TOTAL 1.3 .5 & & 596 & $\$ 19,400.00$ & & & \\
\hline & $35 \%$ Adder for SWP work & & 209 & $\$ 6,790.00$ & $\$ 0.00$ & $\$ 0.00$ & $\$ 6,790.00$ \\
\hline & SUB TOTAL 1.3 .5 & & 805 & $\$ 26,190.00$ & $\$ 5,911,64$ & $\$ 22,598.10$ & $\$ 54,699.74$ \\
\hline & $30 \%$ adder for Const. Suppor & & 241 & $\$ 7,857.00$ & $\$ 0.00$ & $\$ 0.00$ & $\$ 7,857.00$ \\
\hline & | Total 1.3.5 & & 1046 & $\$ 34,047.00$ & $\$ 5,911.64$ & $\$ 22,598.10$ & $\$ 62,556.74$ \\
\hline
\end{tabular}




\section{Project $W-420$}

Stack Monitoring System Upgrades

Estimate Details for Construction Activities (296-P-16)

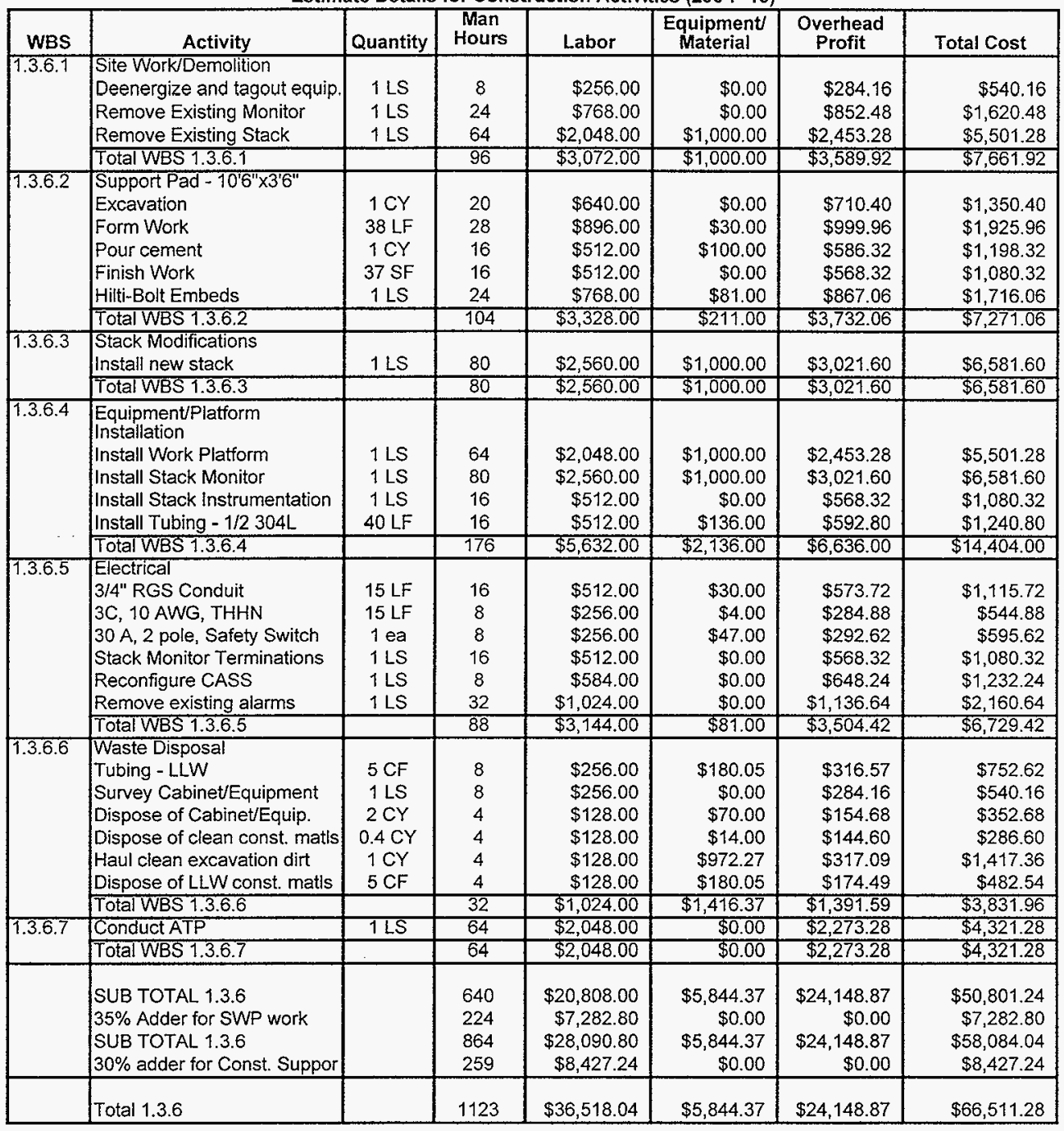




\section{Project W-420}

\section{Stack Monitoring System Upgrades}

Estimate Details for Construction Activities (296-S-15)

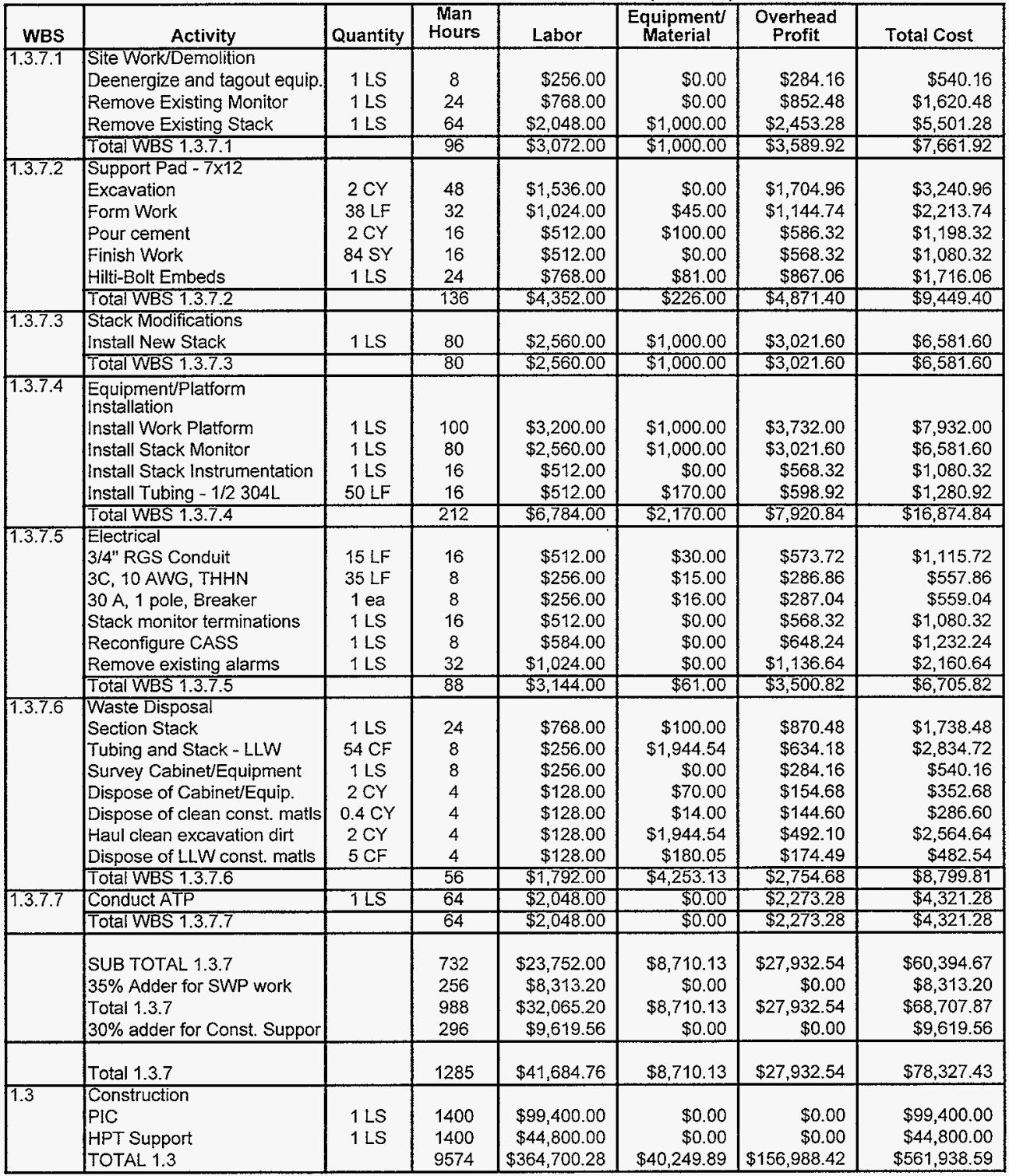

Note: $\quad$ PIC and HPT support included as fulitime support during 175 days of construction. 
HNF-SD-W420-CDR-001, Rev. 0

\section{Project $W-420$}

Stack Monitoring System Upgrades

Estimate Details for Project Management Activities

\begin{tabular}{|c|c|c|c|c|c|c|c|}
\hline WBS & Activity & Quantity & $\begin{array}{c}\text { Man } \\
\text { Hours }\end{array}$ & Labor & $\begin{array}{c}\text { Equipment } \\
\text { Material }\end{array}$ & $\begin{array}{l}\text { Overhead } \\
\text { Profit }\end{array}$ & Total Cost \\
\hline \multirow[t]{3}{*}{1.4 .1} & $\begin{array}{l}\text { Project Mgmt \& Integration } \\
\text { Project Management }\end{array}$ & $1 \mathrm{LS}$ & 430 & $\$ 32,680.00$ & $\$ 0.00$ & $\$ 0.00$ & $\$ 32,680.00$ \\
\hline & Project Engineer & $1 \mathrm{LS}$ & 1680 & $\$ 122,640.00$ & $\$ 0.00$ & $\$ 0.00$ & $\$ 122,640.00$ \\
\hline & Total WBS 1.4 .1 & & 2110 & $\$ 155,320.00$ & $\$ 0.00$ & $\$ 0.00$ & $\$ 155,320.00$ \\
\hline \multirow[t]{2}{*}{1.4 .2} & Business Management & $1 \mathrm{LS}$ & 624 & $\$ 45,552.00$ & $\$ 0.00$ & $\$ 0.00$ & $\$ 45,552.00$ \\
\hline & Total WBS 1.4.2 & & 624 & $\$ 45,552.00$ & $\$ 0.00$ & $\$ 0.00$ & $\$ 45,552.00$ \\
\hline \multirow[t]{2}{*}{1.4 .3} & Configuration Management & $1 \mathrm{LS}$ & 200 & $\$ 5,600.00$ & $\$ 0.00$ & $\$ 0.00$ & $\$ 5,600.00$ \\
\hline & Total WBS 1.4.3 & & 200 & $\$ 5,600.00$ & $\$ 0.00$ & $\$ 0.00$ & $\$ 5,600.00$ \\
\hline \multirow[t]{2}{*}{1.4 .4} & Quality Assurance & $1 \mathrm{LS}$ & 200 & $\$ 14,600.00$ & $\$ 0.00$ & $\$ 0.00$ & $\$ 14,600.00$ \\
\hline & Total WBS 1.4.4 & & 200 & $\$ 14,600.00$ & $\$ 0.00$ & $\$ 0.00$ & $\$ 14,600.00$ \\
\hline \multirow[t]{2}{*}{1.4 .5} & Test \& Eval. Management & $1 \mathrm{LS}$ & 200 & $\$ 14,600.00$ & $\$ 0.00$ & $\$ 0.00$ & $\$ 14,600,00$ \\
\hline & Total WBS 1.4 .5 & & 200 & $\$ 14,600.00$ & $\$ 0.00$ & $\$ 0.00$ & $\$ 14,600.00$ \\
\hline & TOTAL 1.4 & & 3334 & $\$ 235,672.00$ & $\$ 0.00$ & $\$ 0.00$ & $\$ 235,672.00$ \\
\hline
\end{tabular}

\section{Notes:}

1) Assumes a project duration from detailed design of 18 months with a $1 / 8$ FTE Project Manager plus 40 hours for project validation. Also includes $1 / 2$ time Project Engineer with 120 hours for validation work.

2) Assumes cost account manager and administrative assistance 8 hours per week during project duration.

3) Assumes a configuration control clerk 8 hours per week during design, and 40 hours after that.

4) Assumes 1/16 FTE for QA during 18 month project duration.

5) Assumes 200 manhours to review test data and resolve discrepancies. 
Project $W-420$

Stack Monitoring System Upgrades

Estimate Details for Other Project Support Activities

\begin{tabular}{|c|c|c|c|c|c|c|c|}
\hline WBS & Activity & Quantity & $\begin{array}{l}\text { Man } \\
\text { Hours }\end{array}$ & Labor & $\begin{array}{c}\text { Equipment } \\
\text { Material }\end{array}$ & $\begin{array}{c}\text { Overhead } \\
\text { Profit }\end{array}$ & Total Cost \\
\hline \multirow[t]{10}{*}{1.5 .1} & Engineering & & & & & & \\
\hline & FDC Preparation & $1 \mathrm{LS}$ & 160 & $\$ 11,680.00$ & $\$ 0.00$ & $\$ 0.00$ & $\$ 11,680.00$ \\
\hline & Validation Support & $1 \mathrm{LS}$ & 400 & $\$ 29,200.00$ & $\$ 0.00$ & $\$ 0.00$ & $\$ 29,200.00$ \\
\hline & Contract Support & $1 \mathrm{LS}$ & 520 & $\$ 37,960.00$ & $\$ 0.00$ & $\$ 0.00$ & $\$ 37,960.00$ \\
\hline & Operating Procedure Prep. & $1 \mathrm{LS}$ & 320 & $\$ 23,360.00$ & $\$ 0.00$ & $\$ 0.00$ & $\$ 23,360.00$ \\
\hline & Environmental Checklist & $1 \mathrm{LS}$ & 40 & $\$ 2,920.00$ & $\$ 0.00$ & $\$ 0.00$ & $\$ 2,920.00$ \\
\hline & Probe Location Verif. (shop) & $1 \mathrm{LS}$ & 160 & $\$ 11,680.00$ & $\$ 1,000.00$ & $\$ 0.00$ & $\$ 12,680.00$ \\
\hline & Probe Location Verif. (field) & $1 \mathrm{LS}$ & 80 & $\$ 5,840.00$ & $\$ 1,000.00$ & $\$ 0.00$ & $\$ 6,840.00$ \\
\hline & Factory Acceptance Test & $1 \mathrm{LS}$ & 160 & $\$ 11,680.00$ & $\$ 3,670.00$ & $\$ 0.00$ & $\$ 15,350.00$ \\
\hline & Total WBS 1.5.1 & & 1840 & $\$ 134,320.00$ & $\$ 5,670.00$ & $\$ 0.00$ & $\$ 139,990.00$ \\
\hline \multirow[t]{6}{*}{1.5 .2} & Environmental/Permits & & & & & & \\
\hline & DOH Notice & $1 \mathrm{LS}$ & 40 & $\$ 2,920.00$ & $\$ 0.00$ & $\$ 0.00$ & $\$ 2,920.00$ \\
\hline & Site Surveys & $1 \mathrm{LS}$ & 168 & $\$ 5,376.00$ & $\$ 0.00$ & $\$ 0.00$ & $\$ 5,376.00$ \\
\hline & Excavation Permits & $1 \mathrm{LS}$ & 40 & $\$ 2,920.00$ & $\$ 0.00$ & $\$ 0.00$ & $\$ 2,920.00$ \\
\hline & Tie-in Permits & $1 \mathrm{LS}$ & 60 & $\$ 4,380.00$ & $\$ 0.00$ & $\$ 0.00$ & $\$ 4,380.00$ \\
\hline & Total WBS 1.5.2 & & 308 & $\$ 15,596.00$ & $\$ 0.00$ & $\$ 0.00$ & $\$ 15,596.00$ \\
\hline \multirow[t]{12}{*}{1.5 .3} & ATP/OTP Support \& Startup & & & & & & \\
\hline & Prepare and Approve ATP & $1 \mathrm{LS}$ & 160 & $\$ 11,680.00$ & $\$ 0.00$ & $\$ 0.00$ & $\$ 11,680.00$ \\
\hline & ATP Engineering Support & $1 \mathrm{LS}$ & 60 & $\$ 4,380.00$ & $\$ 0.00$ & $\$ 0.00$ & $\$ 4,380.00$ \\
\hline & 40CFR52 Test Procedure & $1 \mathrm{LS}$ & 160 & $\$ 11,680.00$ & $\$ 0.00$ & $\$ 0.00$ & $\$ 11,680.00$ \\
\hline & 40CFR52 Test & $1 \mathrm{LS}$ & 840 & $\$ 26,880.00$ & $\$ 0.00$ & $\$ 0.00$ & $\$ 26,880.00$ \\
\hline & 40CFR52 Eng. Support & $1 \mathrm{LS}$ & 160 & $\$ 11,680.00$ & $\$ 0.00$ & $\$ 0.00$ & $\$ 11,680.00$ \\
\hline & 40CFR52 Test Report & $1 \mathrm{LS}$ & 80 & $\$ 5,840.00$ & $\$ 0.00$ & $\$ 0.00$ & $\$ 5,840.00$ \\
\hline & Prepare and Approve OTP & $1 \mathrm{LS}$ & 160 & $\$ 11,680.00$ & $\$ 0.00$ & $\$ 0.00$ & $\$ 11,680.00$ \\
\hline & Conduct OTP & $1 \mathrm{LS}$ & 240 & $\$ 7,680.00$ & $\$ 0.00$ & $\$ 0.00$ & $\$ 7,680.00$ \\
\hline & OTP Engineering Support & $1 \mathrm{LS}$ & 120 & $\$ 8,760.00$ & $\$ 0.00$ & $\$ 0.00$ & $\$ 8,760.00$ \\
\hline & Turnover to Operations & $1 \mathrm{LS}$ & 400 & $\$ 29,200.00$ & $\$ 0.00$ & $\$ 0.00$ & $\$ 29,200.00$ \\
\hline & Total WBS 1.5.3 & & 2380 & $\$ 129,460.00$ & $\$ 0.00$ & $\$ 0.00$ & $\$ 129,460.00$ \\
\hline \multirow[t]{4}{*}{1.5 .4} & Training & & & & & & \\
\hline & Prepare Training Plan & 1 LS & 320 & $\$ 23,360.00$ & $\$ 0.00$ & $\$ 0.00$ & $\$ 23,360.00$ \\
\hline & Conduct Operator Training & $1 \mathrm{LS}$ & 640 & $\$ 20,480.00$ & $\$ 0.00$ & $\$ 0.00$ & $\$ 20,480.00$ \\
\hline & Total WBS 1.5.4 & & 960 & $\$ 43,840.00$ & $\$ 0.00$ & $\$ 0.00$ & $\$ 43,840.00$ \\
\hline \multirow[t]{2}{*}{1.5 .5} & Readiness Review & $1 \mathrm{LS}$ & 240 & $\$ 17,520.00$ & $\$ 0.00$ & $\$ 0.00$ & $\$ 17,520.00$ \\
\hline & Total WBS 1.5 .5 & & 240 & $\$ 17,520.00$ & $\$ 0.00$ & $\$ 0.00$ & $\$ 17,520.00$ \\
\hline \multirow[t]{2}{*}{1.5 .6} & Safety Analysis & $1 \mathrm{LS}$ & 280 & $\$ 20,440.00$ & $\$ 0.00$ & $\$ 0.00$ & $\$ 20,440,00$ \\
\hline & Total WBS 1.5.6 & & 280 & $\$ 20,440.00$ & $\$ 0.00$ & $\$ 0.00$ & $\$ 20,440,00$ \\
\hline & TOTAL 1.5 & & 6008 & $\$ 361,176.00$ & $\$ 5,670.00$ & $\$ 0.00$ & $\$ 366,846.00$ \\
\hline
\end{tabular}

Notes:

1) FDC Preparation - 4 man weeks.

2) Operating procedure assumes 6 engineering man-weeks to prepare and 2 man-weeks for approval.

3) Environmental Checklist assumes 1 man week for preparation.

4) Factory acceptance test assumes two engineers for one week plus travel. Two man weeks for probe location support.

5) Probe location testing assumes 4 man weeks for shop mockup testing and two man weeks for field testing.

6) One engineering man week to prepare DOH notice and resolve questions from regulators.

7) Site surveys assumed a crew of three one shift for each location.

8) ATP preparation assumes 3 engineering man-weeks to prepare and 1 man-week for approval.

9) Conduct of ATP assumes support of an engineer for 60 hours.

10) Stack flow test preparation assumes 3 engineering man-weeks to prepare and 1 man-week for approval.

11) Conduct of stack flow test (40CFR52) assumes a crew of 3 for 40 hours at each location, plus an engineer for 4 weeks.

12) Stack flow test report assumes two engineering man-weeks to prepare.

13) OTP preparation assumes 3 engineering man-weeks to prepare and 1 man-week for approval.

14) Conduct of OTP assumes a crew of 3 for 16 hours at each location, plus an engineer. 
15) Turnover to operations work assumes 20 hours per week for 20 weeks.

16) Training plan assumes 8 engineering man-weeks to prepare and approve

17) Conduct of operator training assumes 40 operators for 16 hours.

18) Operational Readiness review assumes three reviewers for two weeks.

19) Six engineering man weeks for safety assessment preparation and one man week for review and approval. 


\section{Appendix B}

Conceptual Project Schedule 


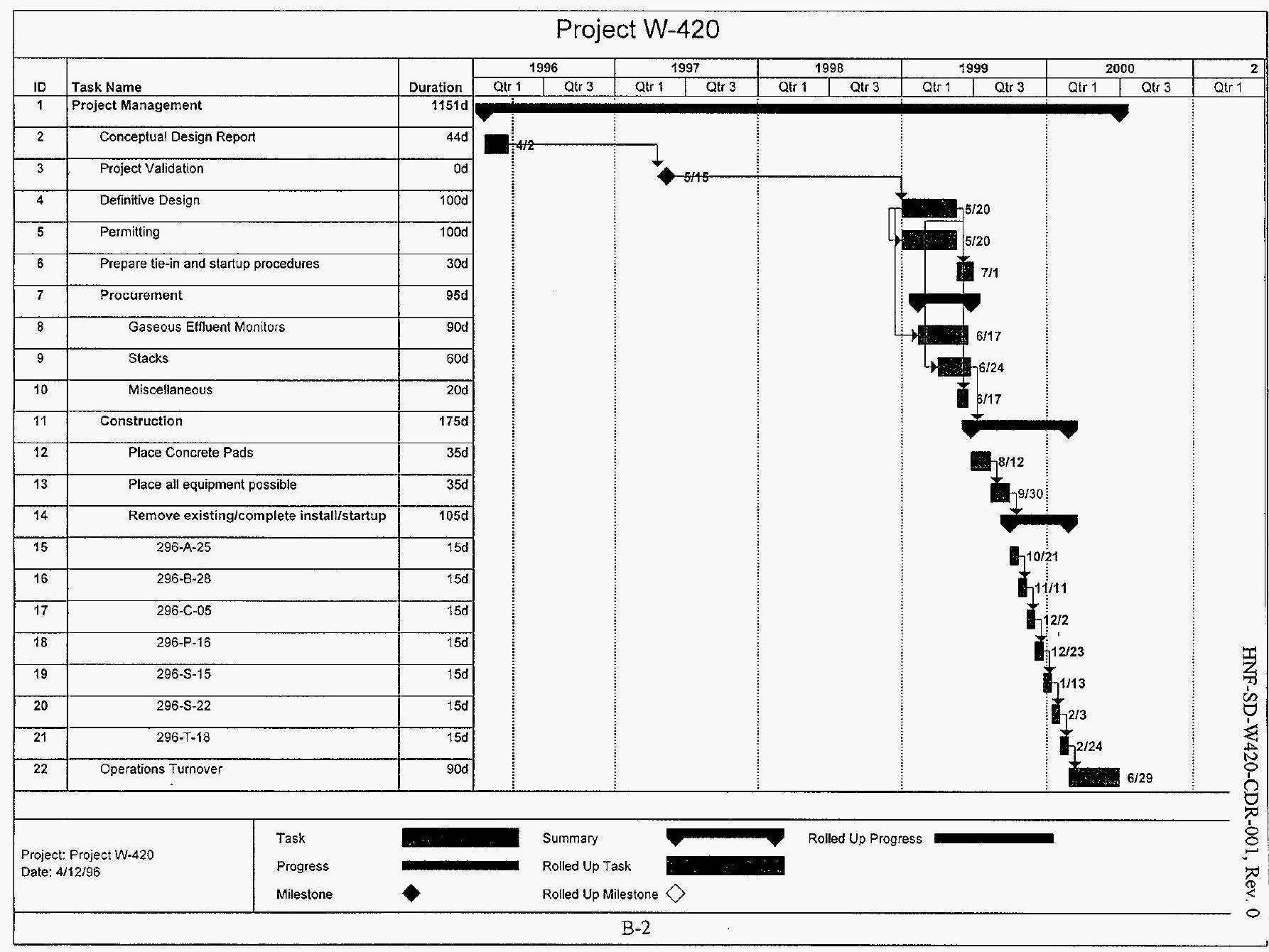




\section{Appendix C Energy Conservation Report}

At the time of the preparation of this report, all electrical load information was not available from the stack monitor vendor. However, for the equipment running full time (vacuum pump, radiation monitor and associated electronics, data collection computer, temperature transmitter, flow transmitter, and humidity probe) the estimated load is approximately $147 \times 10^{6} \mathrm{BTU} / \mathrm{yr}\left(4.3 \times 10^{4}\right.$ $\mathrm{kW}$-hr/yr) for all seven units. This load is considerably less than $500 \times 10^{6} \mathrm{BTU} / \mathrm{yr}\left(1.5 \times 10^{5}\right.$ kW-hr/yr) where DOE Order 6430.1A criteria apply. 10 Code of Federal Regulation (CFR) 435 is also not applicable to this project, as all facilities are unoccupied process equipment enclosures. The instrument cabinets contain small heating units, but no active cooling is required. 


\section{Appendix D \\ Economic Analysis and Life-Cycle Cost Analysis}

A Life-Cycle Cost Analysis (LCCA) was conducted to determine the expected operations and maintenance costs for the life cycle. Because the stack monitor is a required piece of equipment, comparisons with other alternatives were not made. Disposal costs are not calculated. The LCCA was prepared for an average individual unit as the cost differences between locations is very minimal. The average life cycle used was 22.5 years.

\section{Initial Capital Costs}

The average initial capital cost was $\$ 431,000$ per unit.

\section{Annual Operations and Maintenance Costs}

The cost of major electronic equipment in each stack monitor is approximately $\$ 24,000$. Electronic equipment of this nature typically fails and needs replacement every ten years. It was therefore estimated that $\$ 2,400$ of equipment would need to be replaced per unit per year. It was further estimated that 40 man hours would be needed to replace the equipment. Routine maintenance was estimated as 4 man hours per month to replace record sampler filters and to conduct routine monthly checks. In addition, semi-annual calibrations with inspection of the sample probe was estimated to require 32 man hours per year. At a labor rate of $\$ 32 / \mathrm{hr}$ the total annual labor maintenance costs were estimated to be $\$ 3,840$. The total annual Operations and Maintenance costs including labor and materials is $\$ 6,240$.

\section{Annual Energy Costs}

The annual energy use per unit is $6,143 \mathrm{kw}$-hrs per year.

\section{Life-Cycle Cost Determination}

The initial capital costs, annual Operations and Maintenance costs, and the annual energy usage was then entered into BLCC4 which is a life-cycle costing program prepared by the National Institute of Standards and Testing (NIST). BLCC4 uses standard Federal discount rates to determine the total life cycle cost in today's dollars. The BLCC4 input and output files are attached, with the overall life cycle cost for each unit coming to $\$ 513,403$. 
QI filename $=$ GEMS.QI

Analysis type $=$ Federal Analysis--Projects subject to OMB A-94

Project name = Gaseous Effluent Monitors

Base Date of Study $=1996$

Service Date $\quad=1998$

Study Period $=24 / 6$ years $/$ months

Discount rate $=2.7 \%$

Inflation rate $=0.00 \%$

Cap replacements and residual values (if any) NOT included as investment costs.

Residual values NOT calculated for capital components.

Residual values NOT calculated for capital replacements.

Common energy data

Energy type:

Units:

Price per unit:

Escalation type code:
\#1

Electric

(kWh)

$\$ 0.060$

Data for DOE escalation rates:

DOE Escalation Rate File = ENCOST95

Rate Schedule Type $=3$

State Abbreviation = WA

DOE Price escalation rates for Electric

\begin{tabular}{rrrrrrrr} 
Year Rate $(\%)$ & Year Rate $(\%)$ & Year Rate $(\%)$ & Year Rate $(\%)$ & Year Rate $(\%)$ \\
\hline $1996-0.2299$ & 2006 & -0.3269 & 2016 & 0.4070 & & \\
$1997-0.5600$ & 2007 & 0.3275 & 2017 & 0.4052 & & \\
$1998-0.2640$ & 2008 & 0.5896 & 2018 & 0.4347 & & \\
1999 & 0.5632 & 2009 & 0.8762 & 2019 & 0.4328 & & \\
2000 & 0.9563 & 2010 & 0.9050 & 2020 & 0.4002 & & \\
2001 & 0.4916 & 2011 & 0.4155 & & & & \\
2002 & -0.0650 & 2012 & 0.4137 & & & & \\
2003 & 0.0650 & 2013 & 0.4121 & & & & \\
2004 & -0.1303 & 2014 & 0.4103 & & & & \\
$2005-0.4885$ & 2015 & 0.4401 & & &
\end{tabular}

Number of alternatives in file $=1$

Number of groups in file $=1$

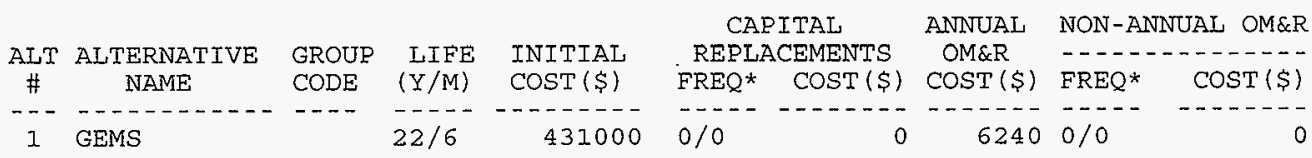

*FREQ $=$ Frequency of occurrence (in years/months)

\begin{tabular}{|c|c|c|c|c|}
\hline $\begin{array}{c}\text { ALT } \\
\#\end{array}$ & $\begin{array}{l}\text { ALTERNATIVE } \\
\text { NAME }\end{array}$ & $\begin{array}{r}\text { GROUP } \\
\text { CODE }\end{array}$ & $\begin{array}{c}\text { ANNUAL } \\
\text { Electric } \\
\text { (kWh) }\end{array}$ & $\begin{array}{l}\text { AN. ELEC. } \\
\text { DEMAND } \\
\text { CHARGE (\$) }\end{array}$ \\
\hline & GEMS & & 6143 & 0 \\
\hline
\end{tabular}


BLCC Quick Input Program (QI2.1-95) 04-01-1996/13:33:43

QI Eilename = GEMS.QI

Analysis type = Federal Analysis--Projects subject to OMB A-94

Project name = Gaseous Effluent Monitors

Base date of study $=1996$

Service date $=\quad 1998$

Study Period $=24 / 6$ years $/$ months

Service Period $=22 / 6$ years $/$ months

Discount rate $=2.7 \%$

Annually recurring costs and energy costs discounted from end of year. DOE energy price escalation rate file = ENCOST95

Number of alternatives in file $=1$

Number of groups in file $=1$

Note: Project alternatives displayed in increasing order of investment cost

Group code:

Alternative

Name

-.-.-......

GEMS

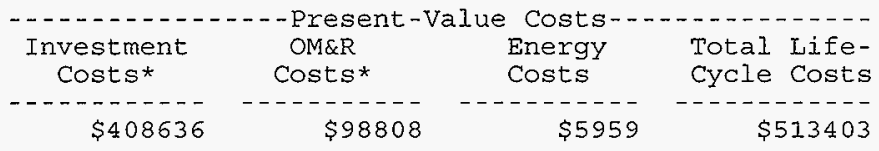

Comparative measures are only calculated for the alternative with lowest LCC relative to alternative with the lowest present-value investment cost. Can't compute comparative economic measures for one alternative only.

* Investment costs include only initial investment. Capital replacements (if any) are included under OM\&R costs.

Residual values are not calculated. 


\section{Appendix E \\ Plant Forces Work Review}

No work by the operating contractor is anticipated for this project, therefore, a Plant Forces Work Review is not required. 
UPGRADES - PROJECT W-420 - Report No. 961129-001, Rev. 0

\section{Appendix F \\ Work Breakdown Structure}




\section{Project W-420}

\section{Work Breakdown Structure}

April 1, 1996

The $X$ designator indicates the stack being modified (i.e $1,2,3$ etc.)

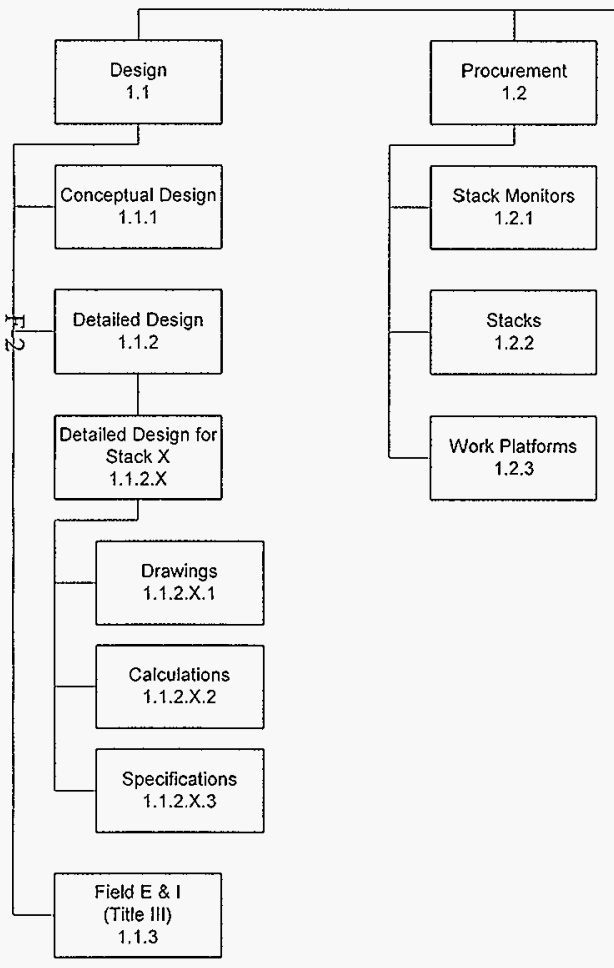

1.0

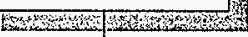

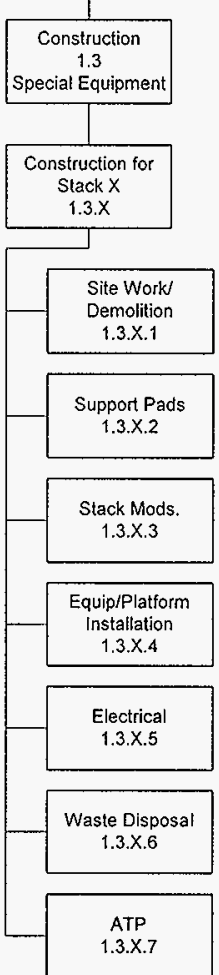

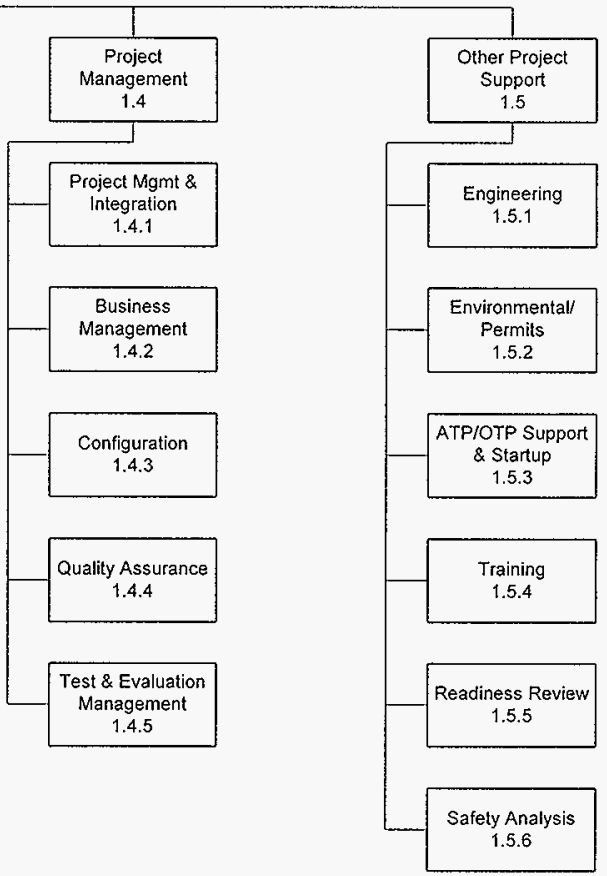

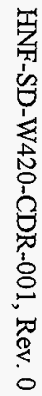


Appendix G

Outline Specifications 


\section{DIVISION 2 - SITE WORK}

Section $02200 \quad$ Earthwork

1. Excavation for underground pipe and wire conduits.

2. Compacted sand bedding for underground pipe and conduits.: ASTMD 653.

3. Plastic sheet marker for buried piping and conduits.

4. Stabilization of disturbed areas.

\section{DIVISION 3 - CONCRETE}

\section{Section $03300 \quad$ Cast-In-Place Concrete}

1. Concrete construction will be in accordance with American Concrete Institute (ACI) 301 .

2. Concrete Minimum Strength: 4000 psi at 28 days for Safety Class 3 .

3. Reinforcing Steel: ASTM A 615, deformed, Grade 60.

4. Welded Wire Fabric: ASTM A 185.

5. Steel Wire: ASTM A 853.

5. Non-Shrink Grout: Nonmetallic type.

6. Concrete Forms: Wood, steel, or plywood or similar.

7. Sampling and testing of concrete per ACI.

8. Tolerances per ACI 117. 


\section{DIVISION 5-METALS}

\section{Section $05500 \quad$ Metal Fabrications}

1. Fabricate in accordance with industry standards.

2. Rolled steel shapes and miscellaneous steel: ASTM A 36.

3. Steel Pipe: ASTM A 53, Schedule 40, Grade B; except straight sections may be ASTM A 120 .

4. Guardrails: galvanized steel pipe conforming to ASTM A 123. Zinc coating not less than 2.8 ounces per square foot.

5. Steel grating: Galvanized, ASTM A 123. Zinc coating not less than 2.8 ounces per square foot.

6. Metal decking: Galvanized steel sheet conforming to ASTM A 526.

7. Steel plate: ASTM A 36 or A 283 .

8. Steel bars and rods: ASTM A 36 .

9. Nuts and Bolts: ASTM A 307, Grade A or B. Nuts shall be hexagon series.

10. Expansion anchors: Hilti "Kwik-Bolt II" or HSL.

11. Weld Studs: ASTM A 108: Nelson Stud Welding Company, Type H4L.

12. Welding and visual examination per AWS D1.1 and AWS D1.3. Visual examination will be performed by CWI.

\section{DIVISION 13 - SPECIAL CONSTRUCTION}

Section 13440

Instrumentation

1. Instrumentation specifications are in accordance with WHC-S-0400, Procurement Specification for the Gaseous Effluent Monitoring System. 


\section{DIVISION 15 - MECHANICAL}

\section{Section 15493 Chemical Process Piping Systems}

1. Specifications for the sample transport and sample return piping are in accordance with WHC-S-0400, Procurement Specification for the Gaseous Effluent Monitoring System.

\section{Section $15500 \quad$ Heating, Ventilation, and Air Conditioning}

1. Exhaust ductwork: ASTM A 527 galvanized steel, fabricated in accordance with Sheet Metal and Air Conditioning Contractors Association, Inc (SMACNA) heating, ventilating and air-conditioning (HVAC) Duct Construction Standards, Metal and Flexible.

2. Duct and equipment supports will be fabricated from ASTM A 36 carbon steel, welded.

3. Stacks: Galvanized steel sheet, or carbon steel pipe.

\section{DIVISION 16 - ELECTRICAL}

\section{Section $16400 \quad$ Service and Distribution}

1. Conductors: Stranded copper with type THWN/THHN insulation.

2. Conduit below grade: PVC coated rigid steel.

3. Exposed Conduit: Galvanized rigid steel.

4. Conduit concealed in concrete: Rigid steel.

5. Connections to motors and lighting fixtures: seal tight flexible metal conduit.

6. Distribution panel boards: Bolt-on type circuit breakers with thermal magnetic strips.

7. Disconnects: NEMA Type I enclosures, fusible locking disconnects (UL approved, CSA certified). 
Appendix H

Sketches and Drawings 


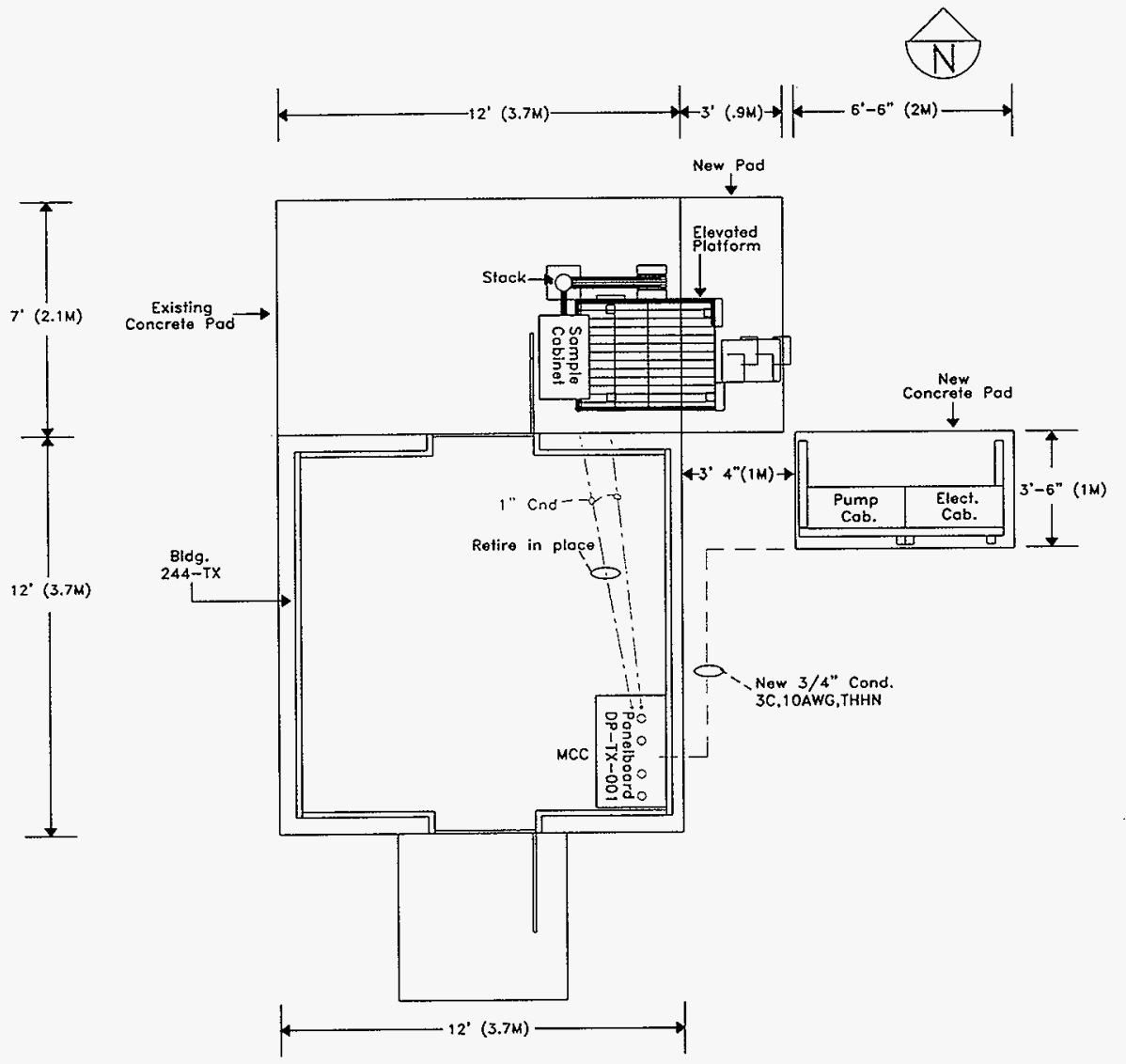

Ref dwg $(H-2-73734)$ \& $(H-2-73794)$

\begin{tabular}{|c|c|c|}
\hline perc & कीin & \multirow{2}{*}{ ARES Corporation } \\
\hline क्ष & & \\
\hline काescos & & \multirow{4}{*}{$\begin{array}{c}\text { EQUIPMENT LAYOUT } \\
\text { PLAN VIEW }\end{array}$} \\
\hline Wric atro & & \\
\hline कास्रCक & & \\
\hline GD GROTH & & \\
\hline 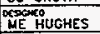 & & fHI WA20 - STACK MONITOR UPGRADE \\
\hline 1 MAR 1996 & & 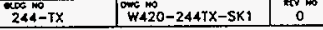 \\
\hline
\end{tabular}




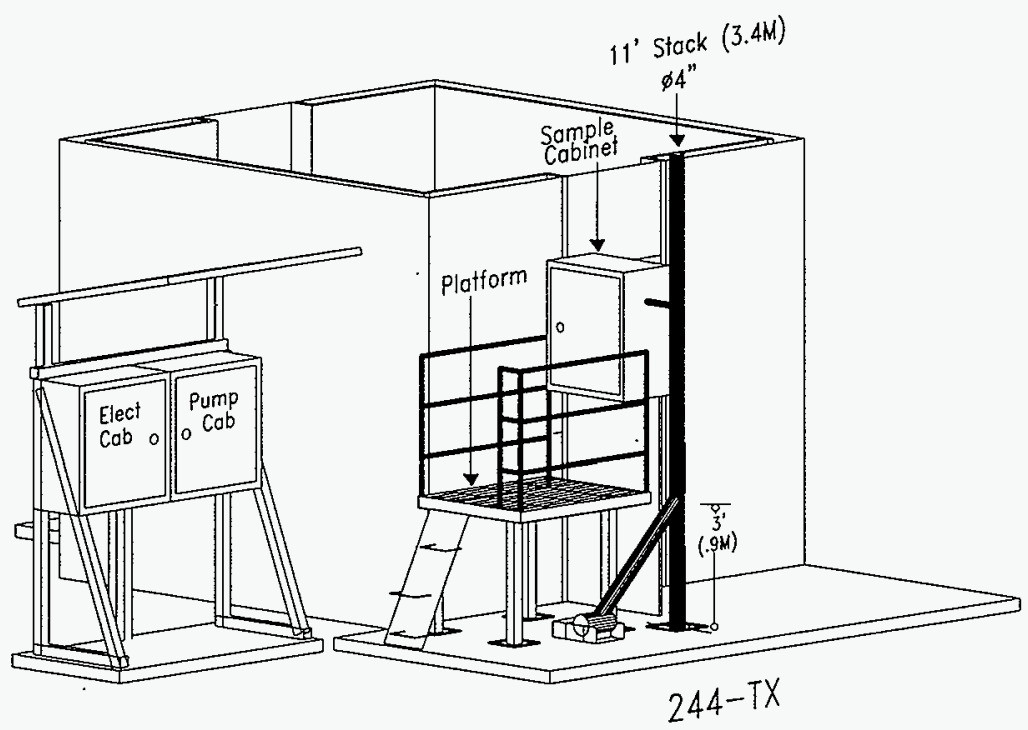

\begin{tabular}{|c|c|c|}
\hline a & aif & Corooration \\
\hline axcas: & & \\
\hline 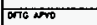 & & \multirow{3}{*}{$\begin{array}{c}\text { EQUIPMENT LAYOUT } \\
\text { VIEW } 1\end{array}$} \\
\hline 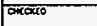 & & \\
\hline GO GROTH & & \\
\hline 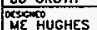 & & FTMU W+2O - STACK MONITOR UPGRAOE \\
\hline ITHAR 1996 & & 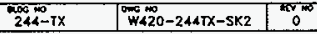 \\
\hline
\end{tabular}




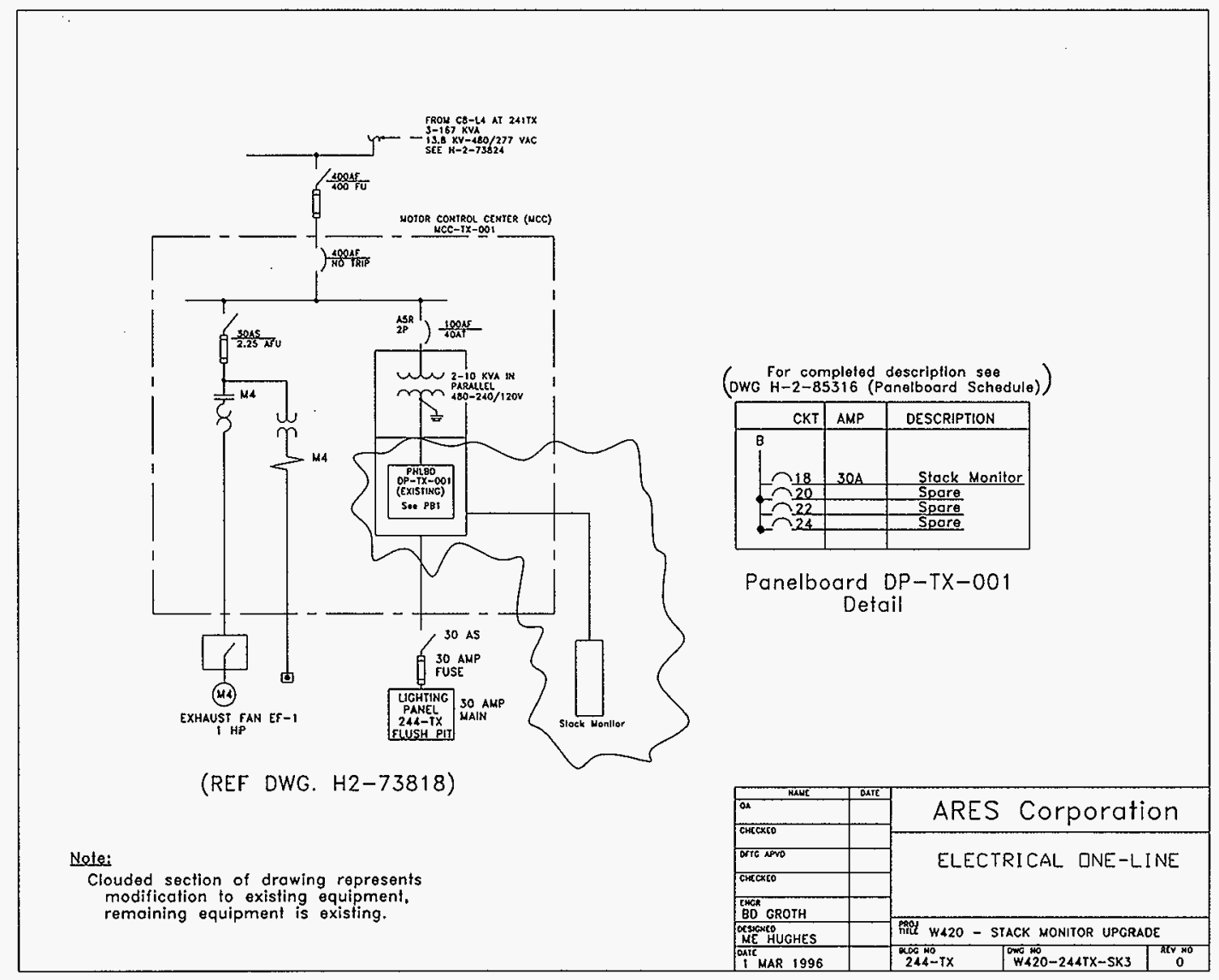

H-4 


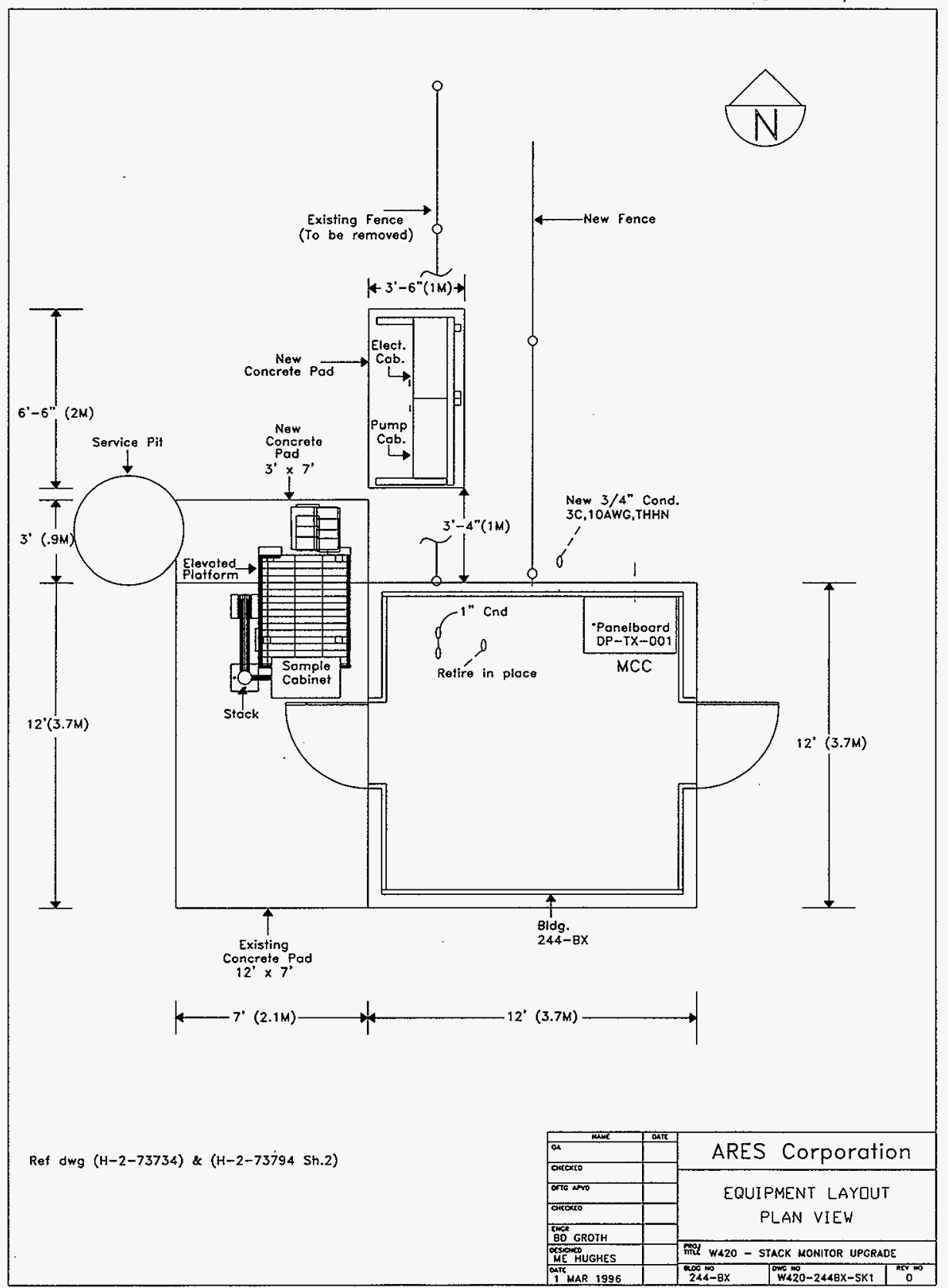




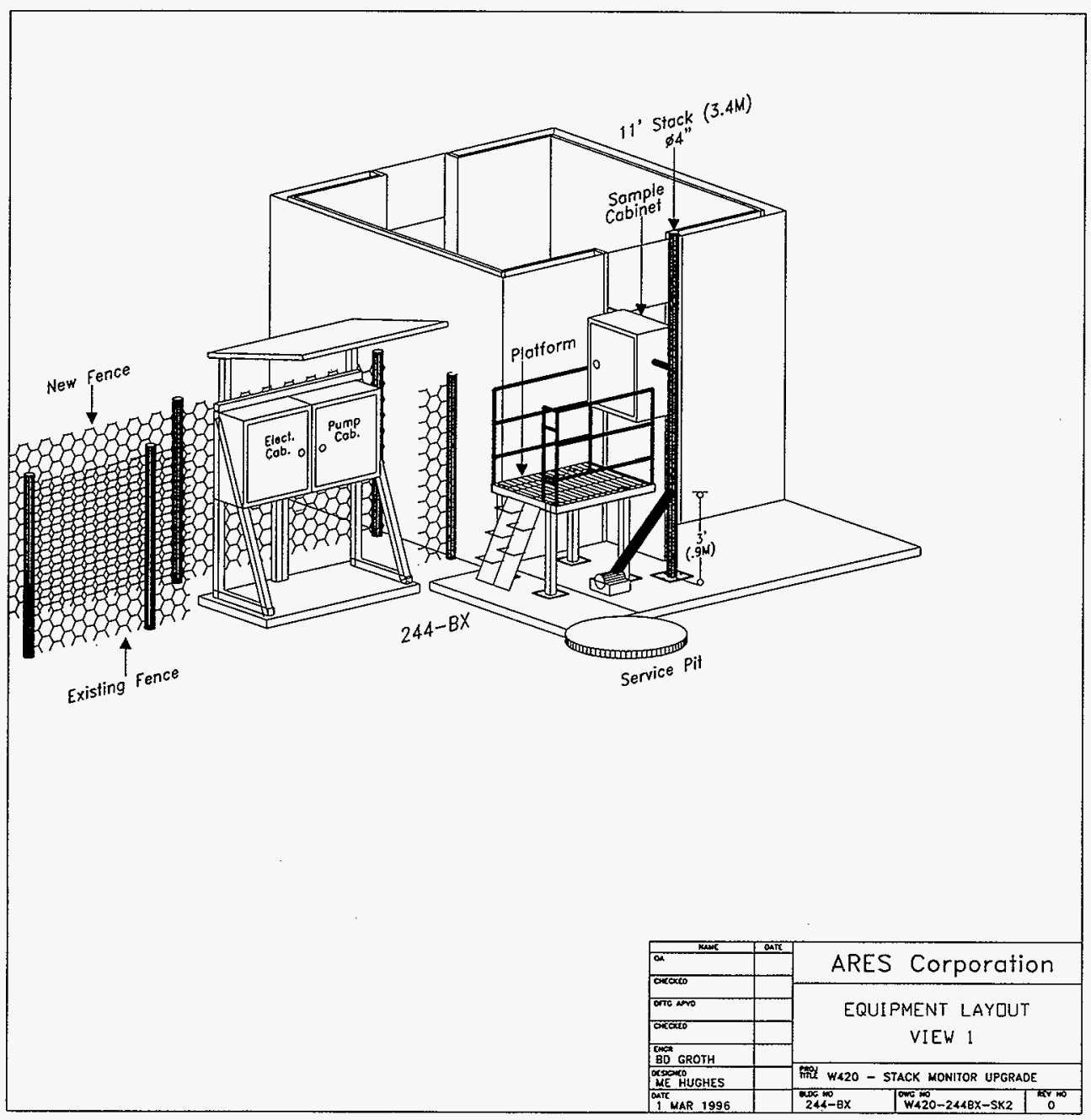




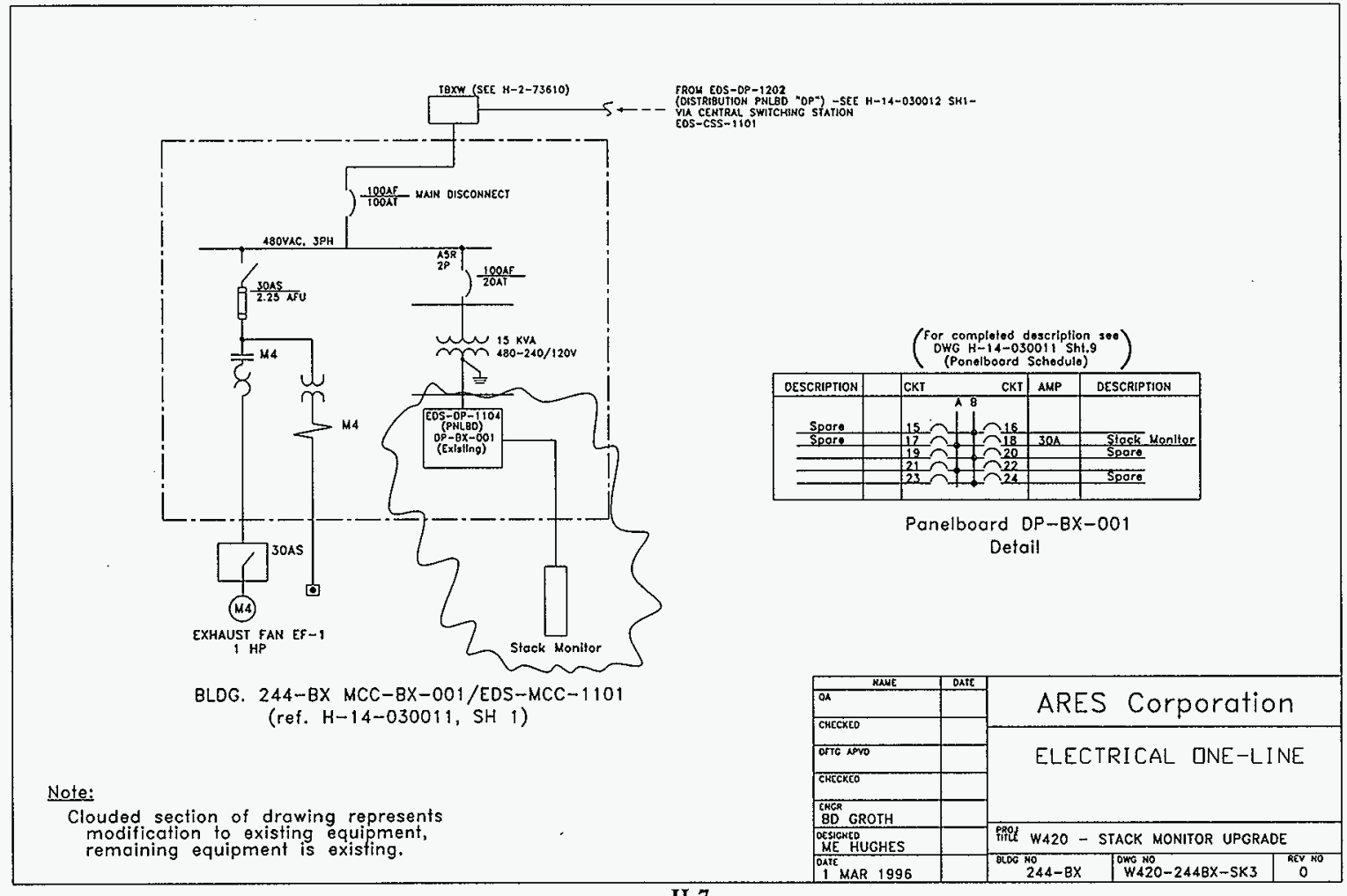




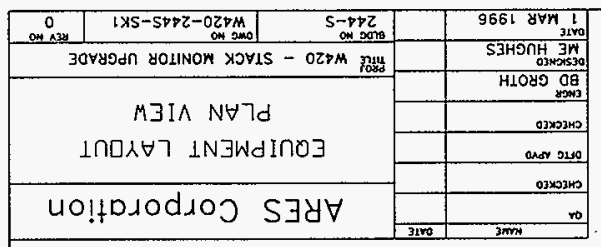

(Z.4S $\square 6 \angle S \angle-Z-H) \cap$

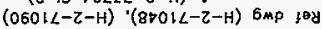

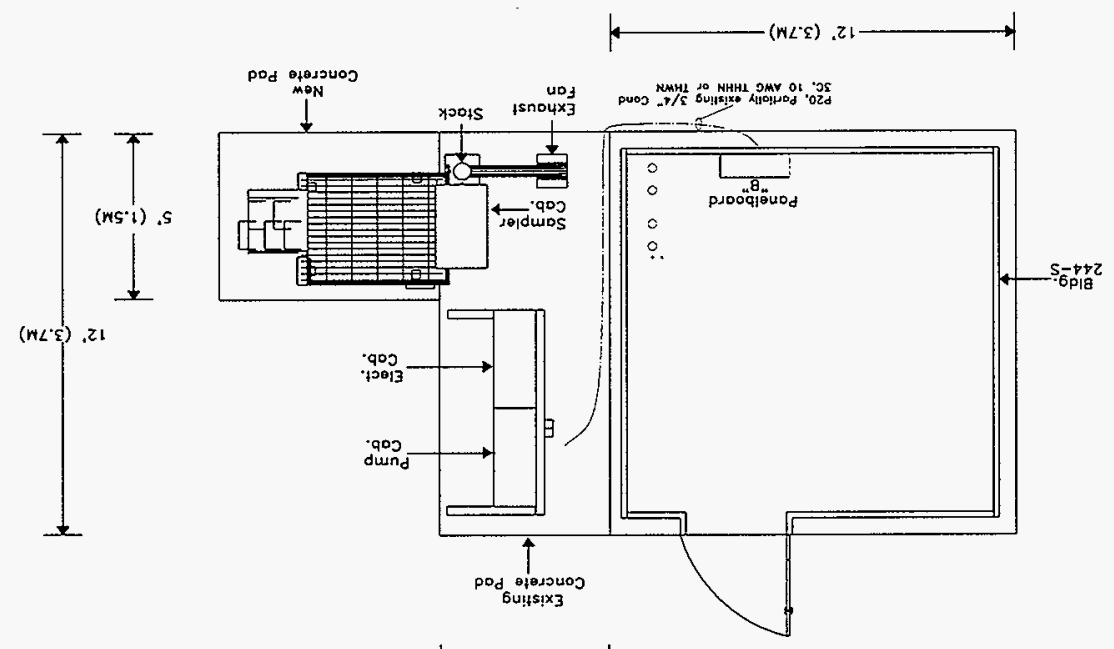

$\longmapsto$ (nz) 


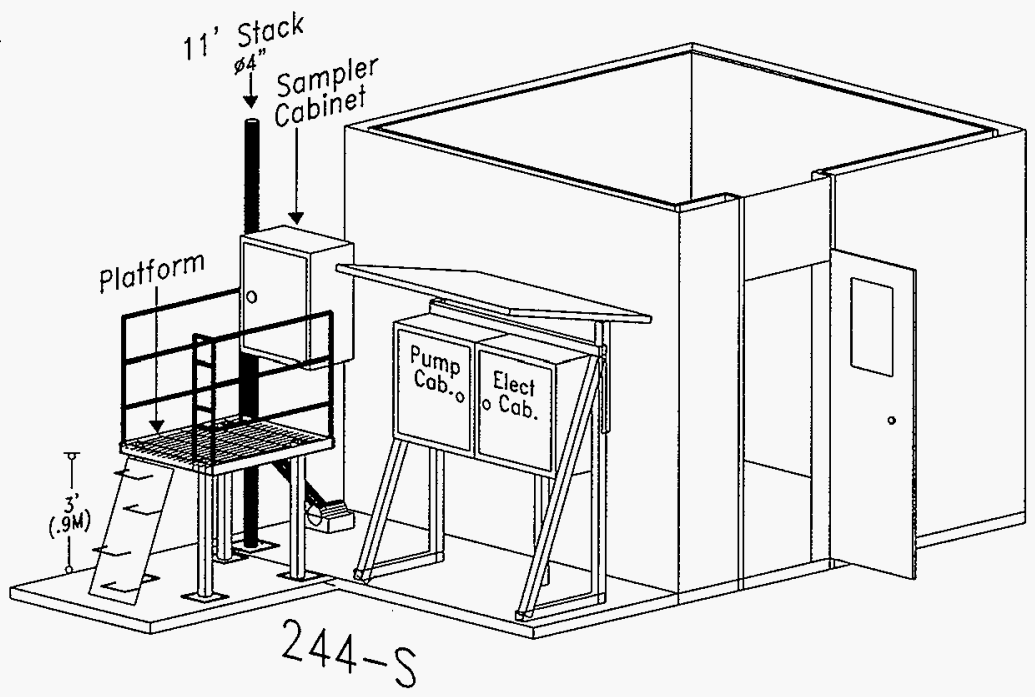

\begin{tabular}{|c|c|c|c|c|}
\hline OA RAME & DARE & \multirow{2}{*}{\multicolumn{3}{|c|}{ ARES Corporation }} \\
\hline ax & & & & \\
\hline circosto & & \multirow{4}{*}{\multicolumn{3}{|c|}{$\begin{array}{c}\text { EQUIPMENT LAYOUT } \\
\text { VIEW } 1\end{array}$}} \\
\hline DFTC NEO & & & & \\
\hline CHECKEO & & & & \\
\hline BO GROTH & & & & \\
\hline $\begin{array}{l}\text { OCSSCNEO } \\
\text { ME HUGHES }\end{array}$ & & \multicolumn{3}{|c|}{ ProO W420 - STACK MONITOR UPGRADE. } \\
\hline 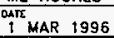 & & $244-5$ & W420-244S-SK2 & $\begin{array}{c}0 \\
\text { ReV } \\
0\end{array}$ \\
\hline
\end{tabular}




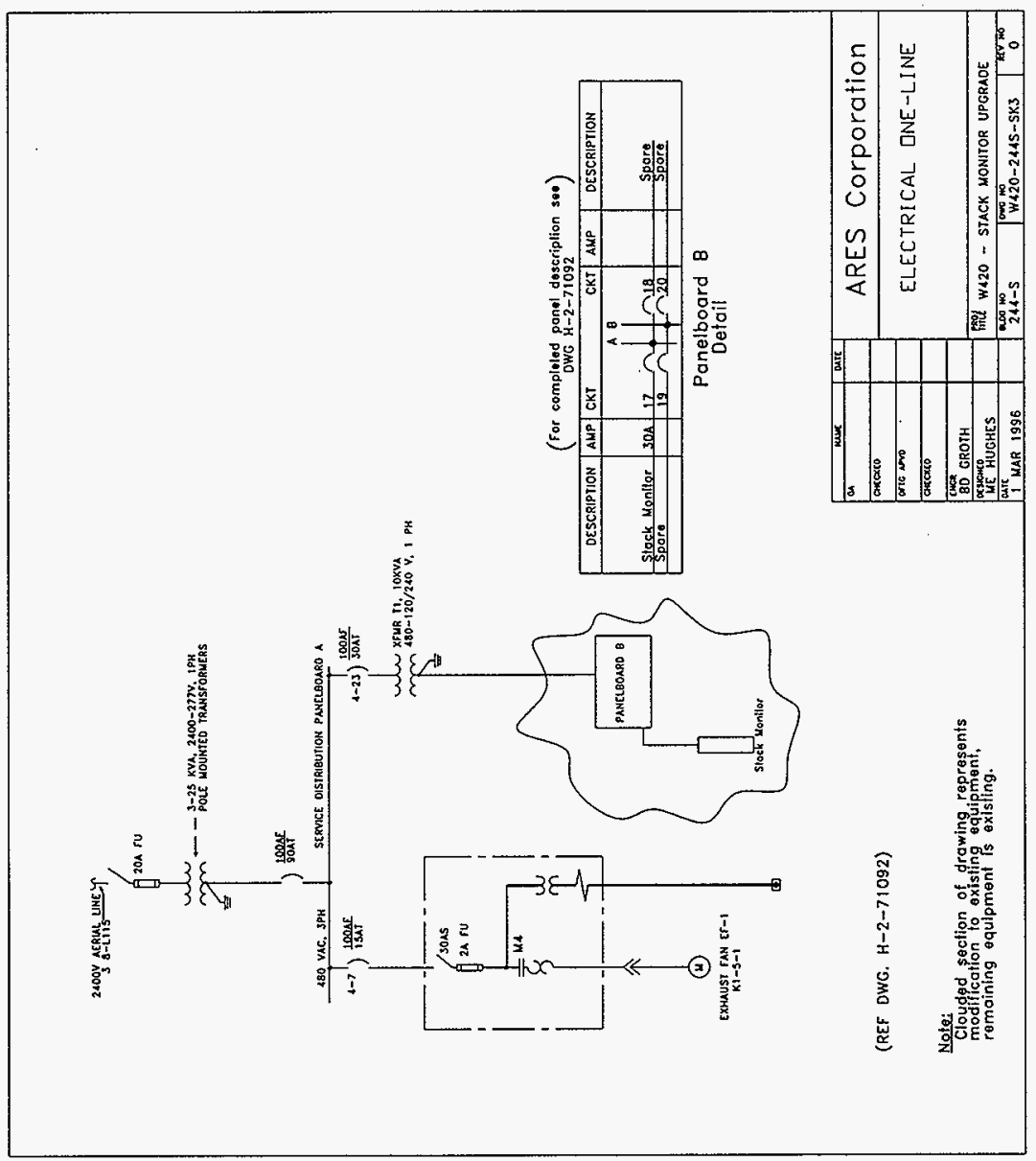




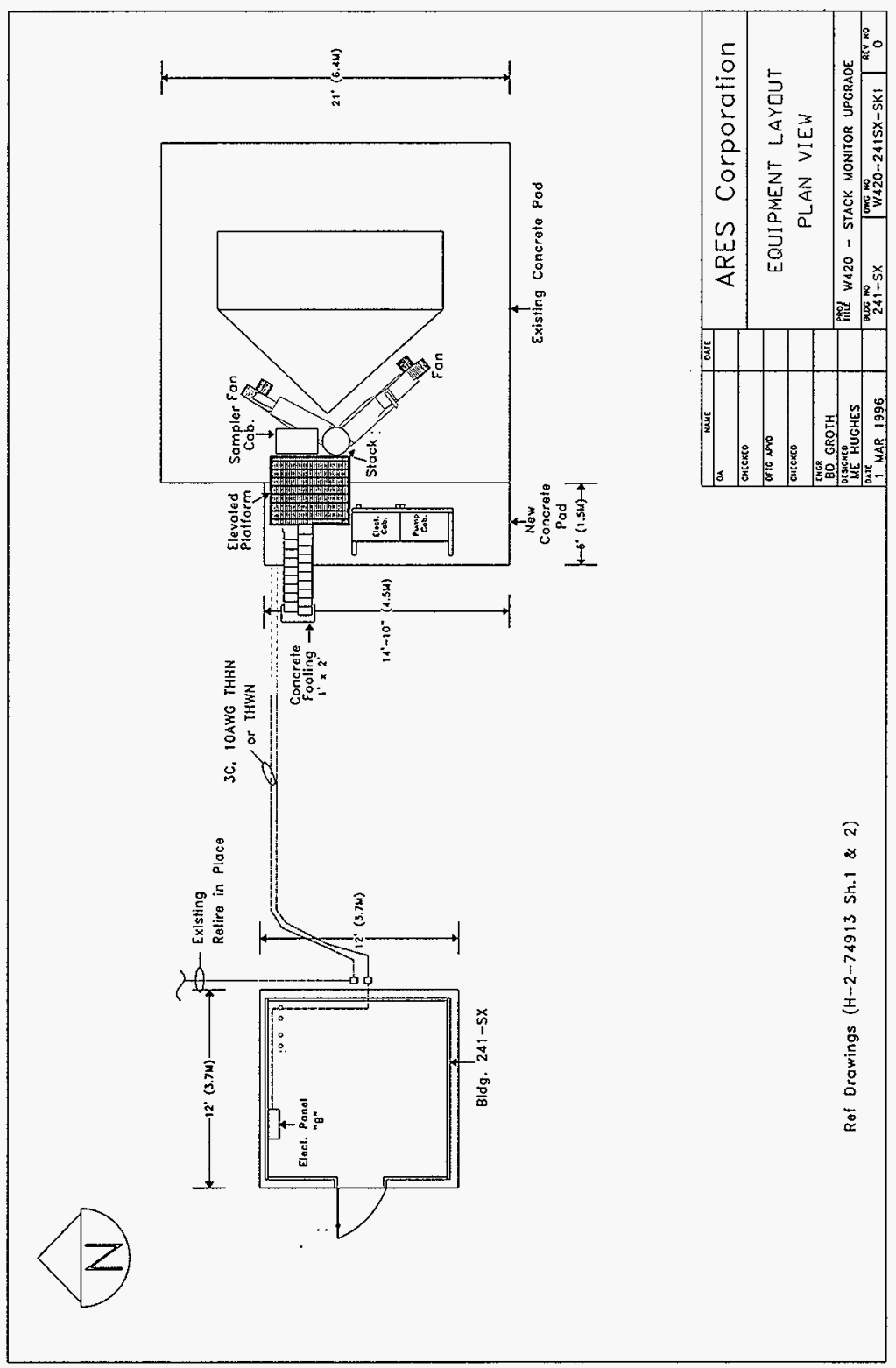




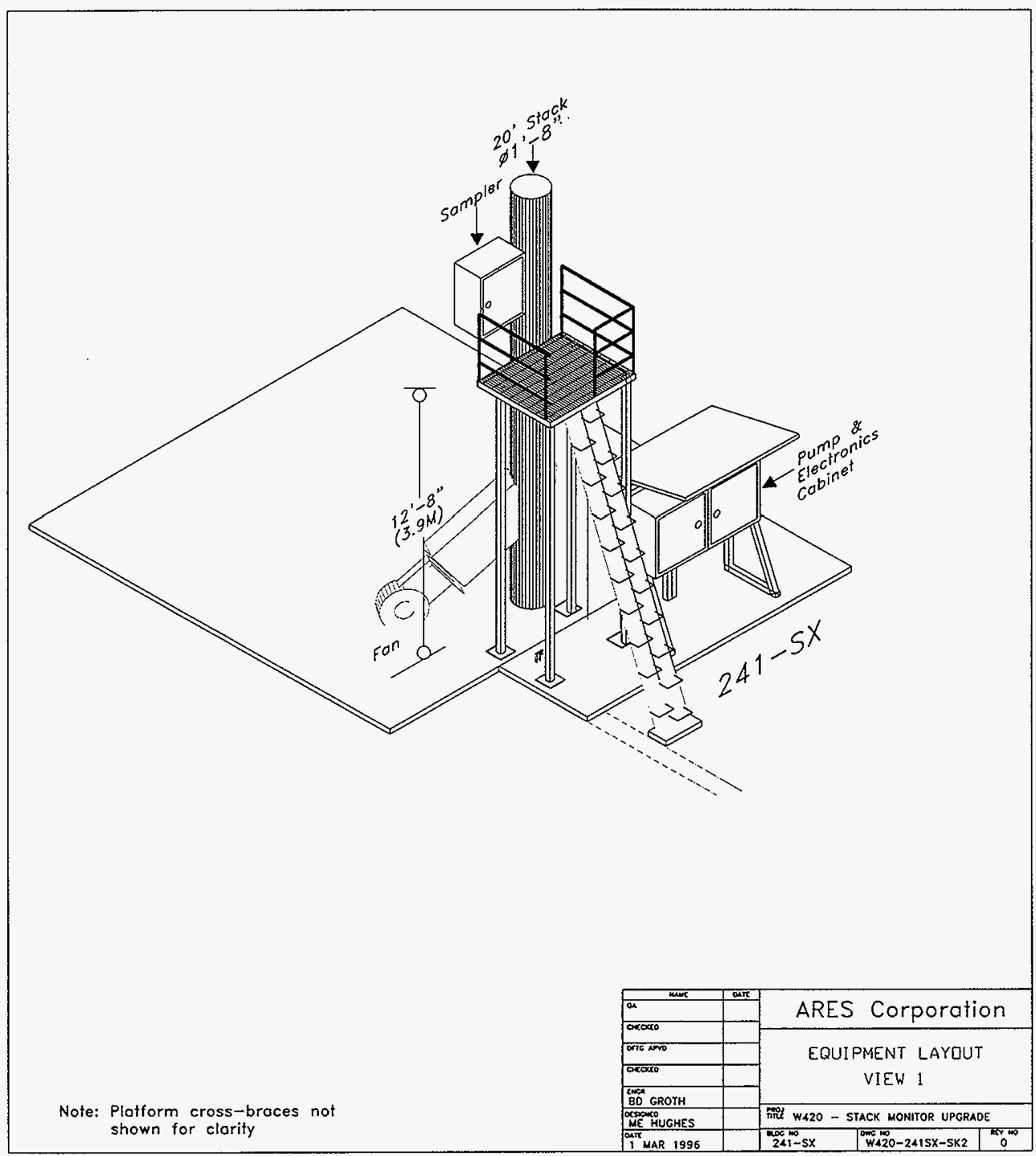




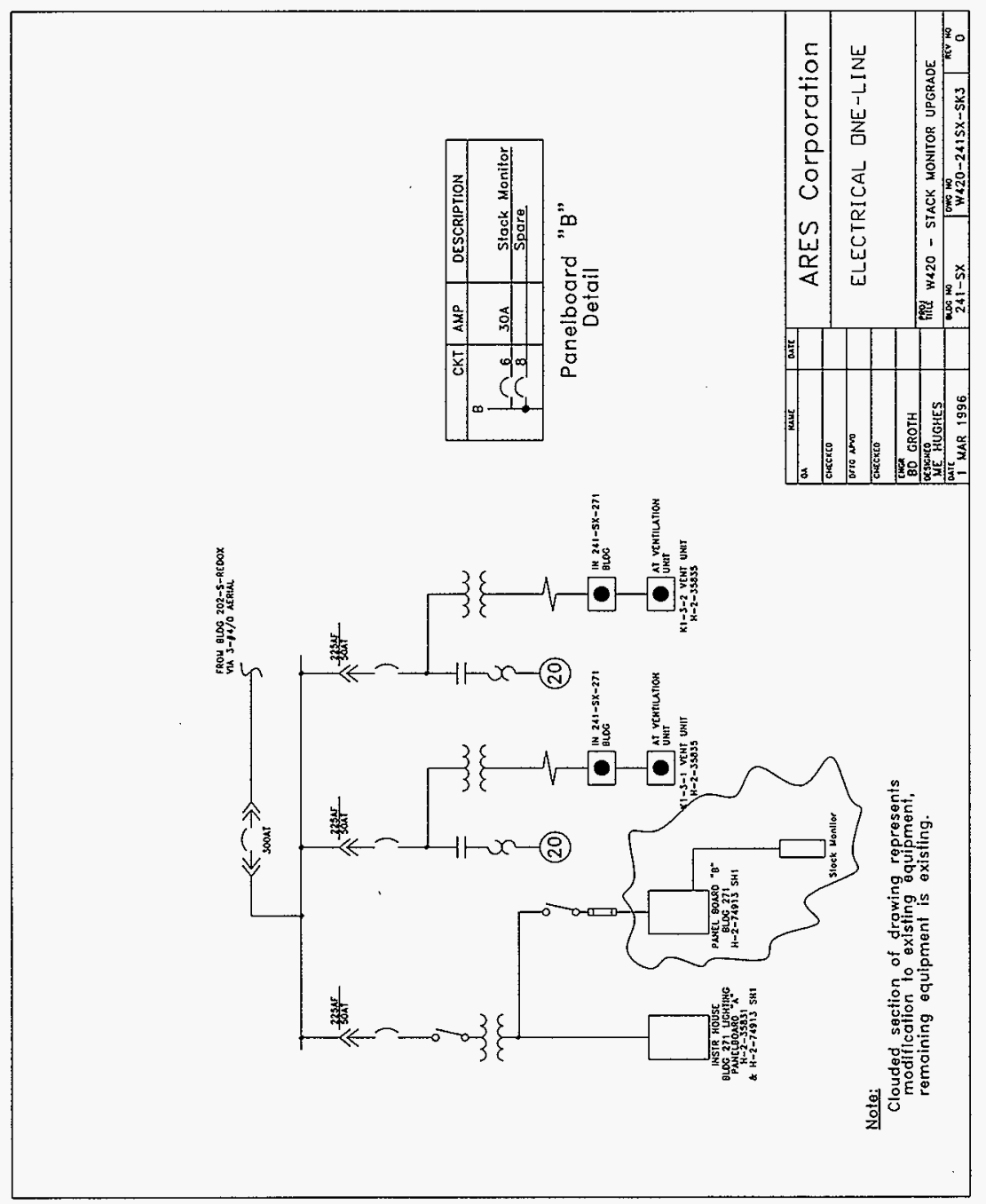




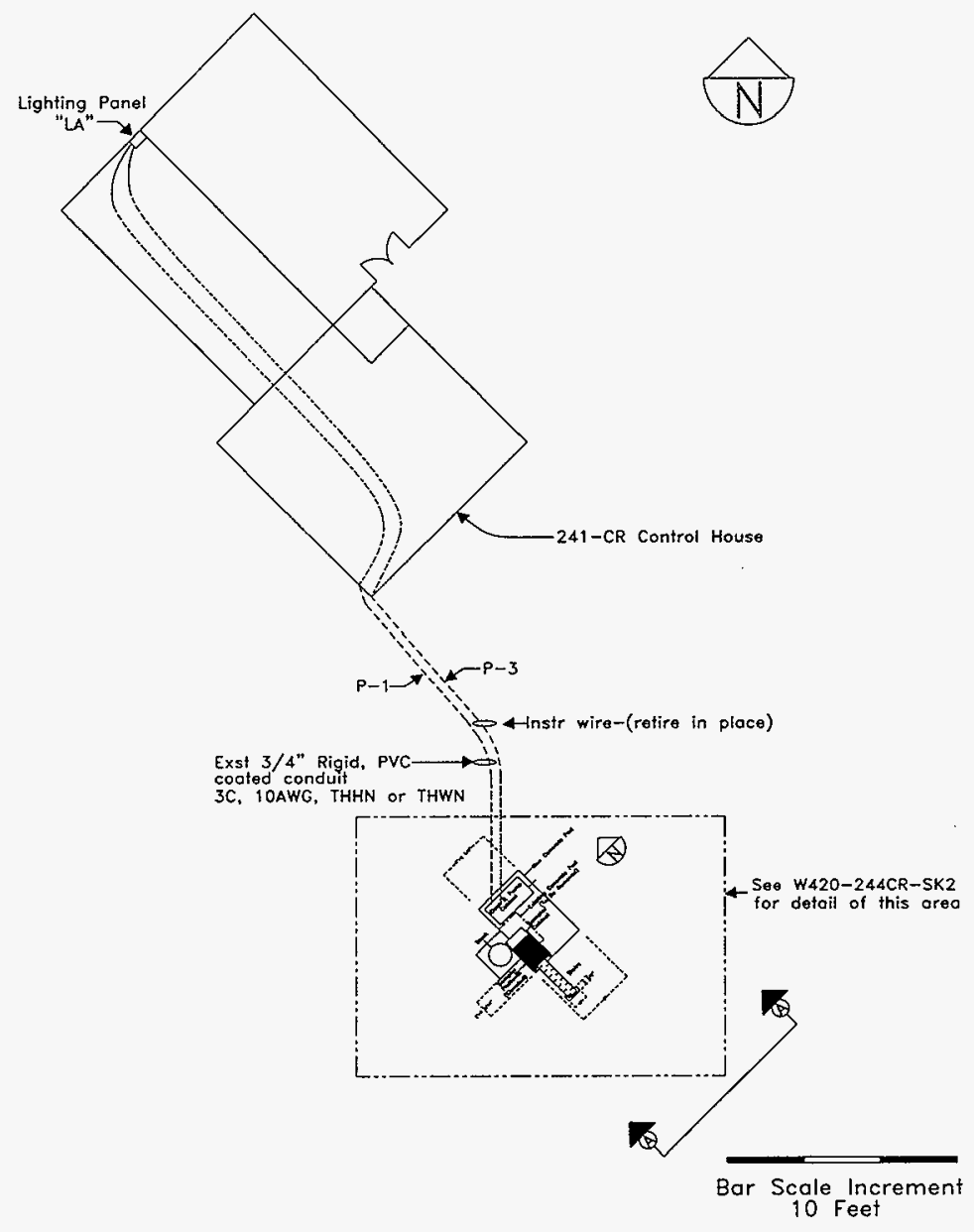

Ref dwg (H-2-92519 Sh. I \& 2). (H-2-41277) \& $(\mathrm{H}-2-73794$ Sh. 2)

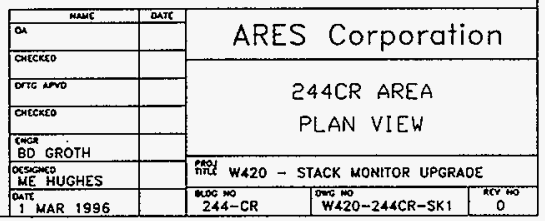




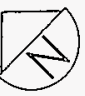

$\stackrel{-6}{\longleftrightarrow}-6^{\prime \prime}(2 M) \longrightarrow$

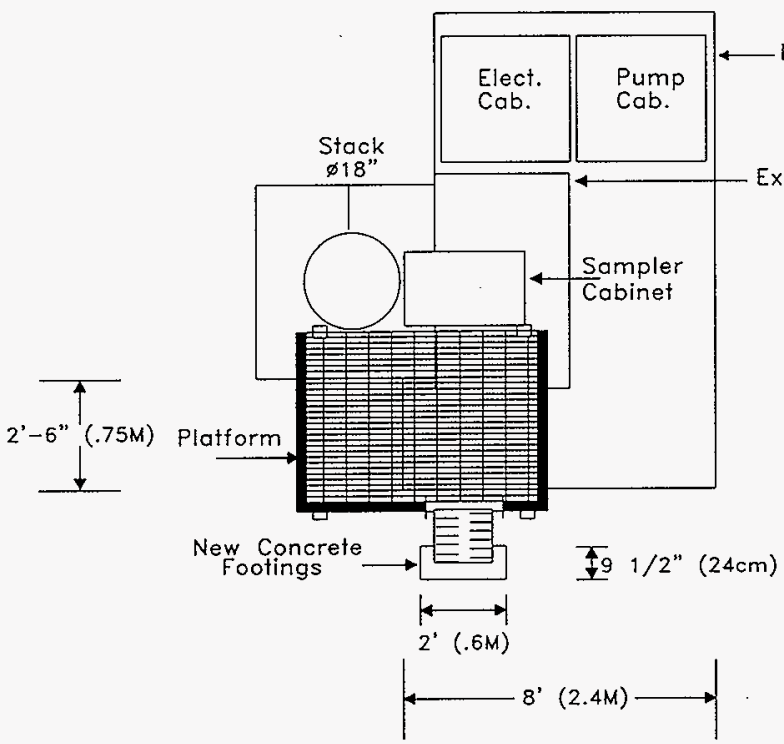

Existing Concrete Pad

(To Be Removed)
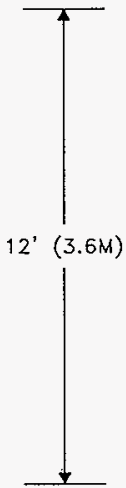

\begin{tabular}{|c|c|c|}
\hline Nex & oats & ARES Corporation \\
\hline xexso & & \multirow{4}{*}{$\begin{array}{l}\text { EQUIPMENT LAYQUT } \\
\text { PLAN VIEW }\end{array}$} \\
\hline 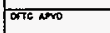 & & \\
\hline सexक & & \\
\hline BD GROTH & & \\
\hline 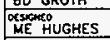 & & mime WAZO - STACK MOMITOR UPGRADE \\
\hline $1_{\text {MAR }}$ & & W420-244CR-SK2 \\
\hline
\end{tabular}




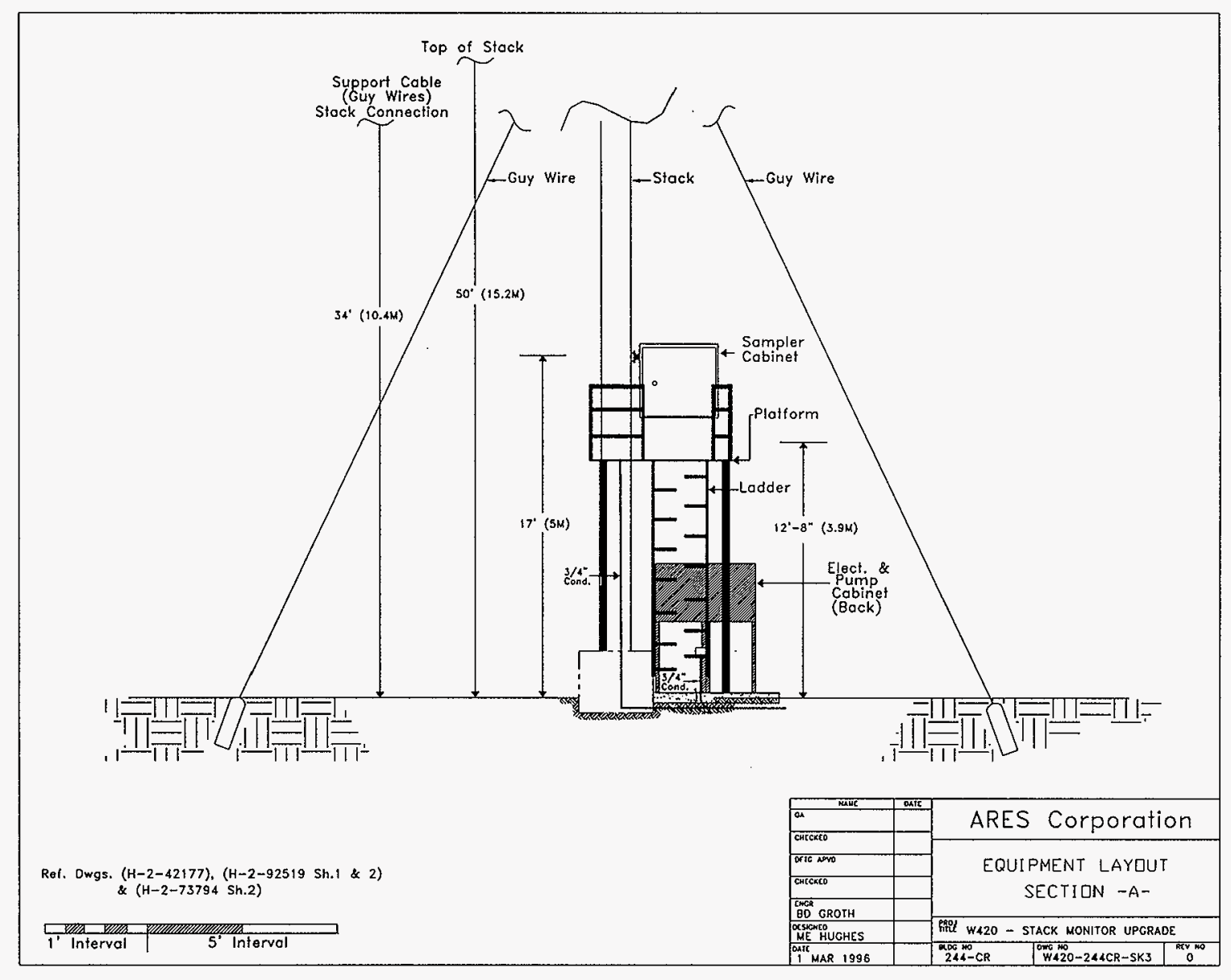

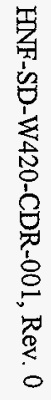




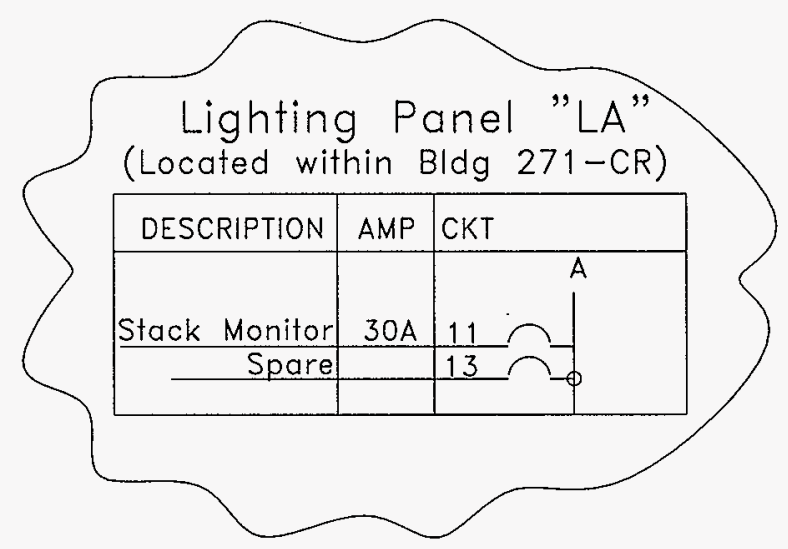

(ref DWG. H-2-41251)

Note:

Clouded section of drawing represents modification to existing equipment,

remaining equipment is existing.

\begin{tabular}{|c|c|c|c|}
\hline HANE & DATE & \multirow{2}{*}{\multicolumn{2}{|c|}{ ARES Corporation }} \\
\hline aA & & & \\
\hline CHECKEO & & \multirow{3}{*}{\multicolumn{2}{|c|}{ ELECTRICAL DNE-LINE }} \\
\hline DFtG $\times 9 \times 0$ & & & \\
\hline CHEC $\times 8 O$ & & & \\
\hline ERGR GROTH & & & \\
\hline DESGMEO HUGHES & & \multicolumn{2}{|l|}{ Fifi WA2O - STACK MONITOR UPGRADE } \\
\hline I MAR 1996 & & $\begin{array}{l}\text { OWG NO } \\
\text { W420-244CR-SK4 }\end{array}$ & $\begin{array}{c}\text { ReV NO } \\
0\end{array}$ \\
\hline
\end{tabular}

H-17 


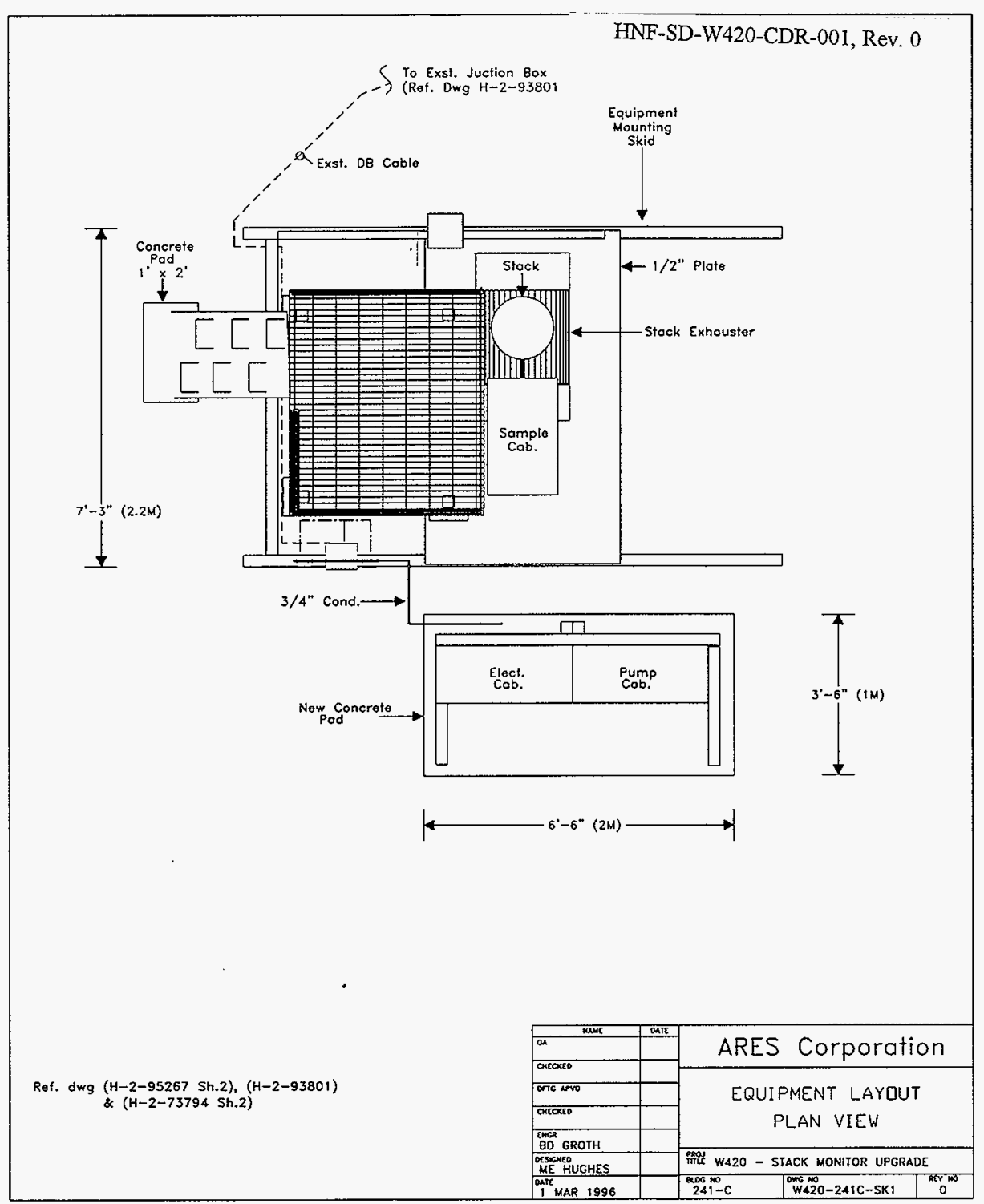




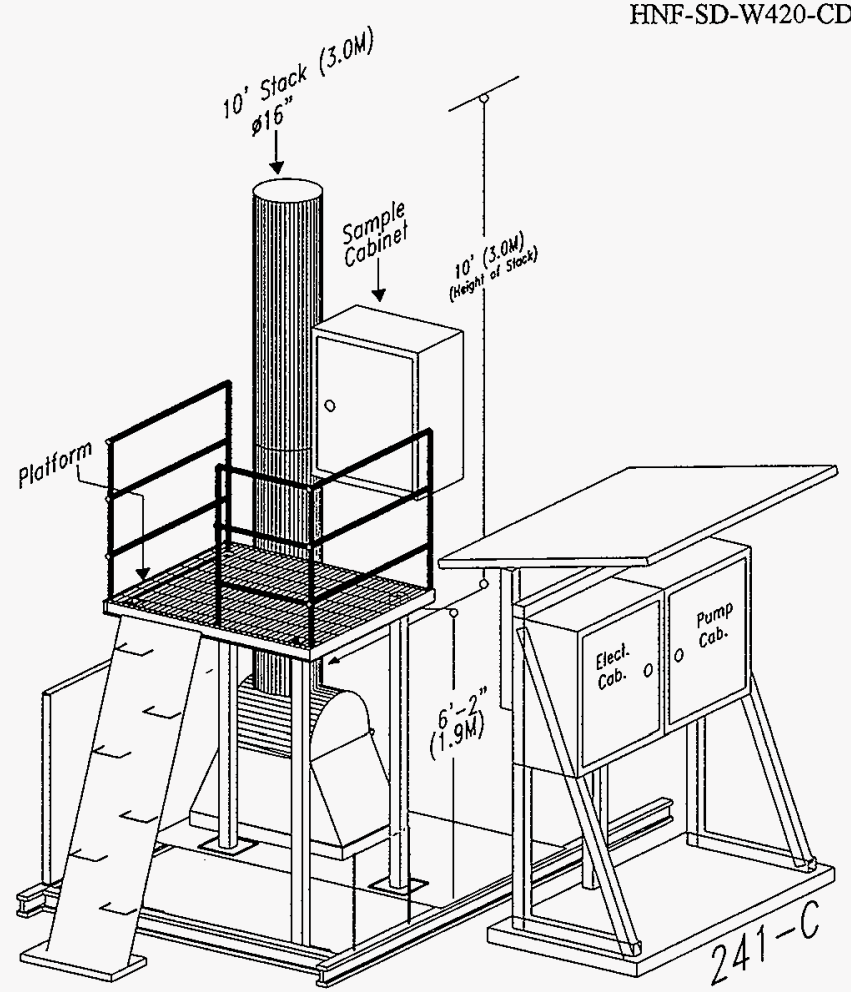

\begin{tabular}{|c|c|c|}
\hline DAC_LAC & Dante & \multirow{2}{*}{ ARES Corporation } \\
\hline काrem & & \\
\hline क्तिक्जण & & \multirow{3}{*}{$\begin{array}{c}\text { EQUIPMENT LAYOUT } \\
\text { VIEW } 1\end{array}$} \\
\hline 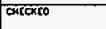 & & \\
\hline $\begin{array}{l}\text { Eman } \\
B D \\
\text { GROTH }\end{array}$ & & \\
\hline $\begin{array}{l}\text { DESCOEED } \\
\text { ME HUGHES }\end{array}$ & & IfFOL WA2O - STACK MONITOR UPGRADE \\
\hline $\begin{array}{ll}\text { OANT } \\
1 \text { MAR } & 1996 \\
\end{array}$ & & $W<20-241 C-5 \times 2$ \\
\hline
\end{tabular}


HNF-SD-W420-CDR-001, Rev. 0

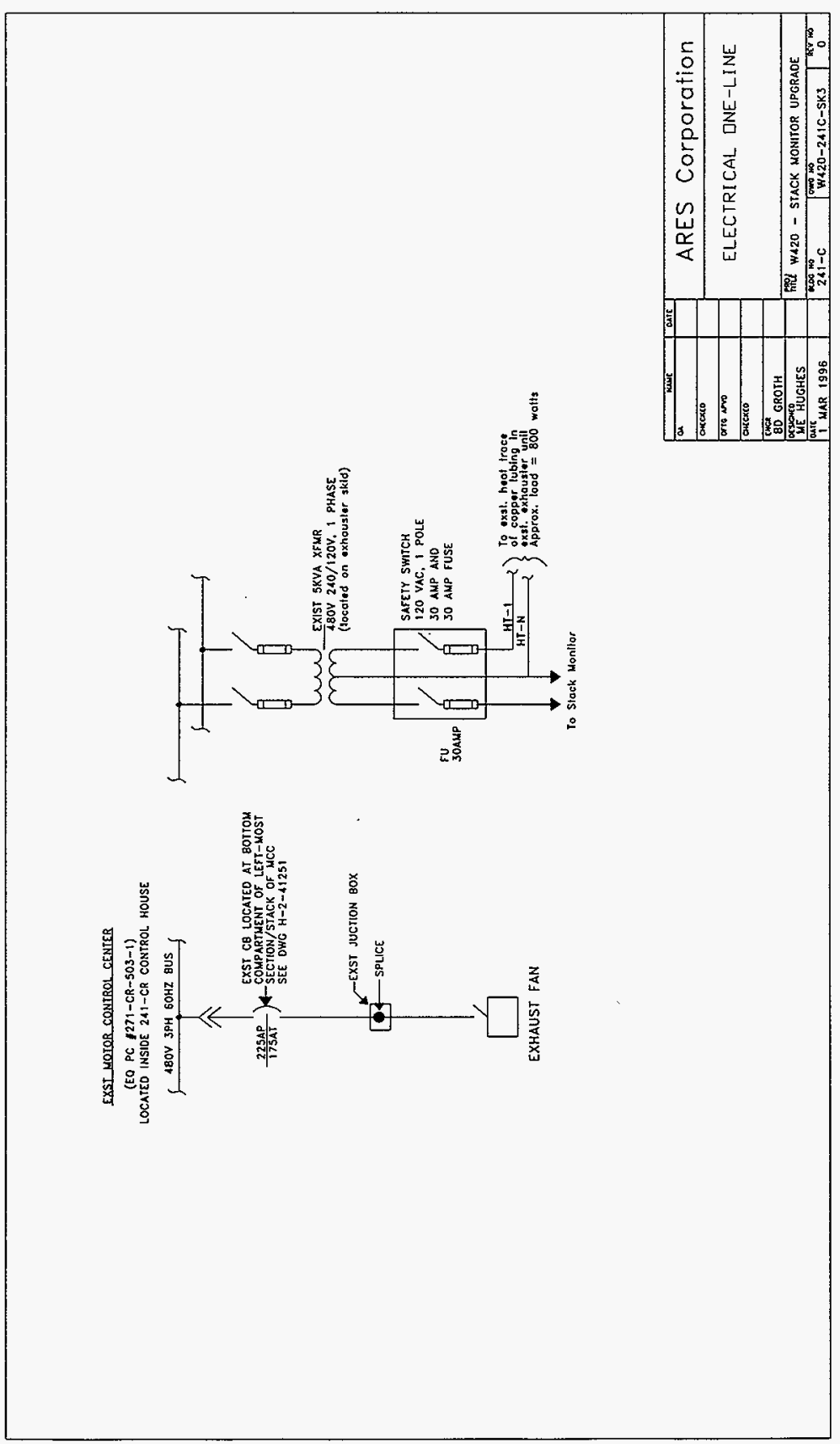



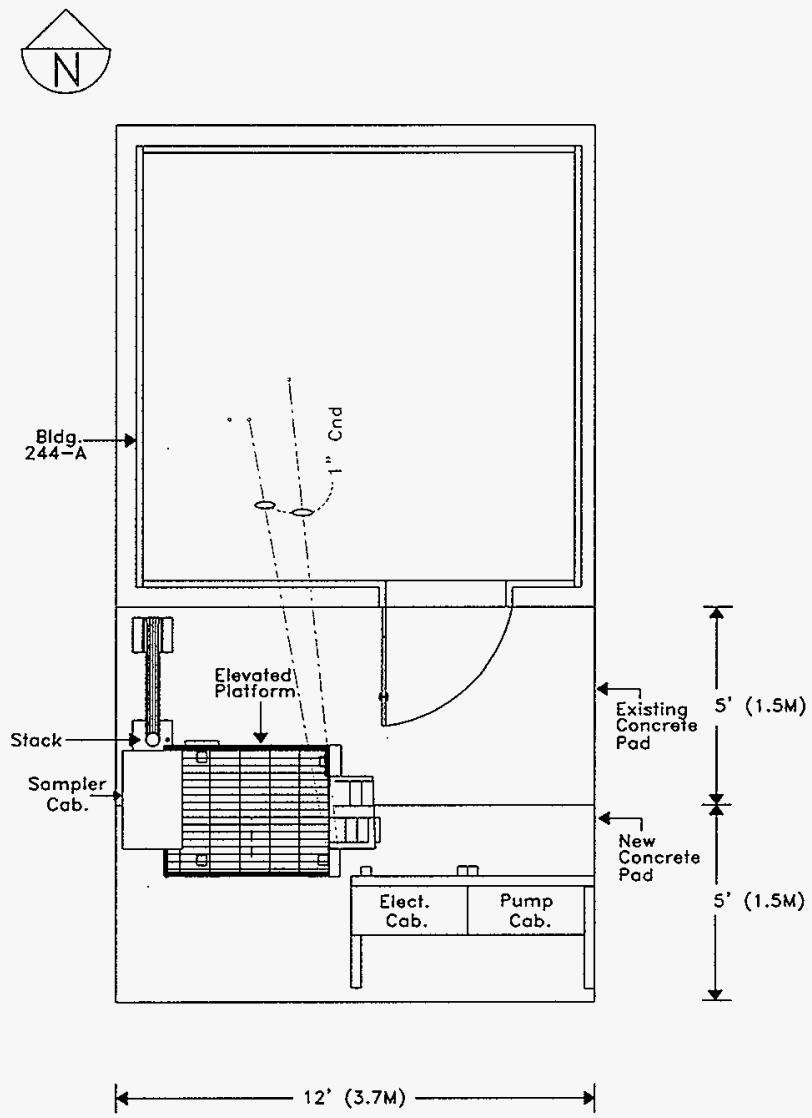

Ref dwg $(\mathrm{H}-2-71048),(\mathrm{H}-2-71090)$

\begin{tabular}{|c|c|c|}
\hline (anda & aniti & \multirow{2}{*}{ ARES Corporation } \\
\hline 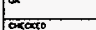 & & \\
\hline $\operatorname{cosecos}$ & & \multirow{3}{*}{$\begin{array}{l}\text { EQUIPMENT LAYOUT } \\
\text { PLAN VIEW }\end{array}$} \\
\hline 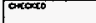 & & \\
\hline GO GROTH & & \\
\hline WE HUGHES & & Finil WA20 - STACK MONITOR UPGRAOE \\
\hline ITAR 1996 & & $\$ 420-244 A-5 K 1$ \\
\hline
\end{tabular}




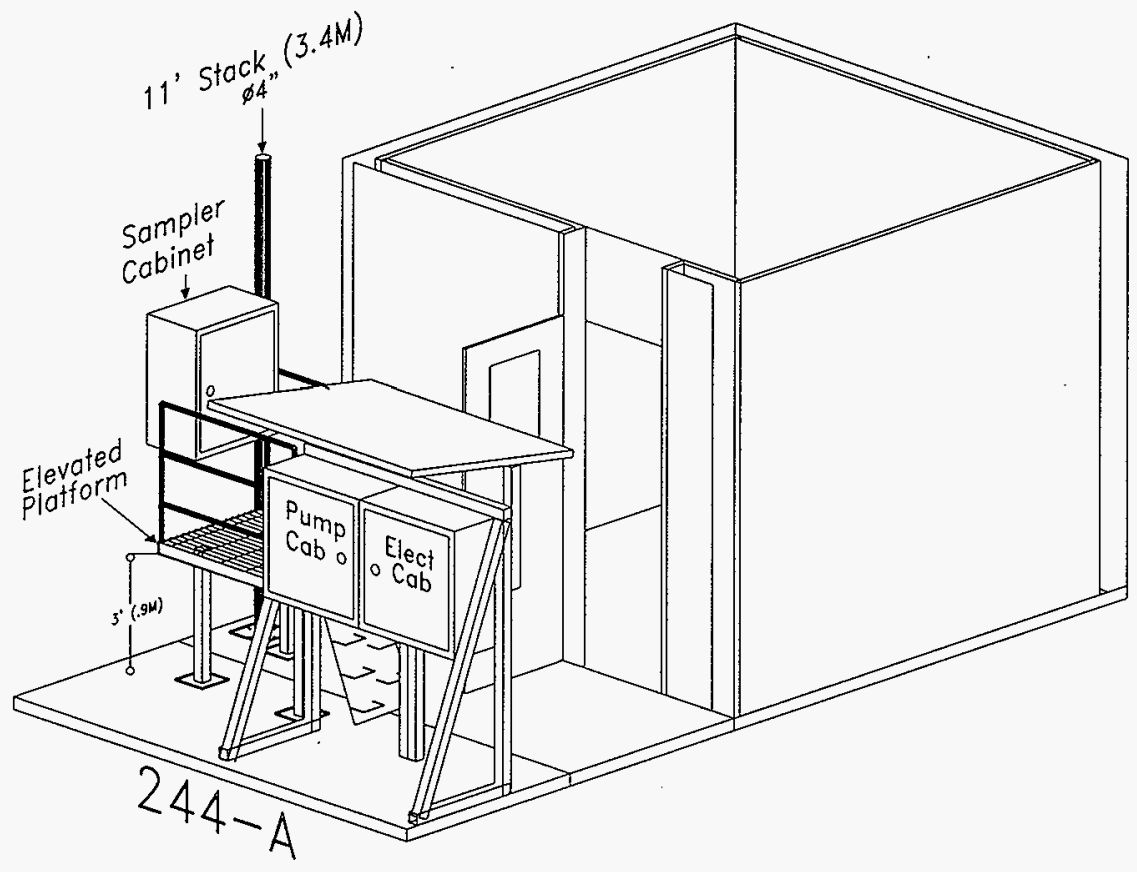

\begin{tabular}{|c|c|c|}
\hline$\alpha$ & ande & ARES Corporation \\
\hline ancosio & & \multirow{4}{*}{$\begin{array}{c}\text { EQUIPMENT LAYOUT } \\
\text { VIEW } 1\end{array}$} \\
\hline काc and & & \\
\hline लात्रण & & \\
\hline BOA GROTH & & \\
\hline 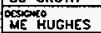 & & TORZE WA20 - STACK MONITOR UPGRADE \\
\hline 19.8 & & W420-244A-SK2 \\
\hline
\end{tabular}




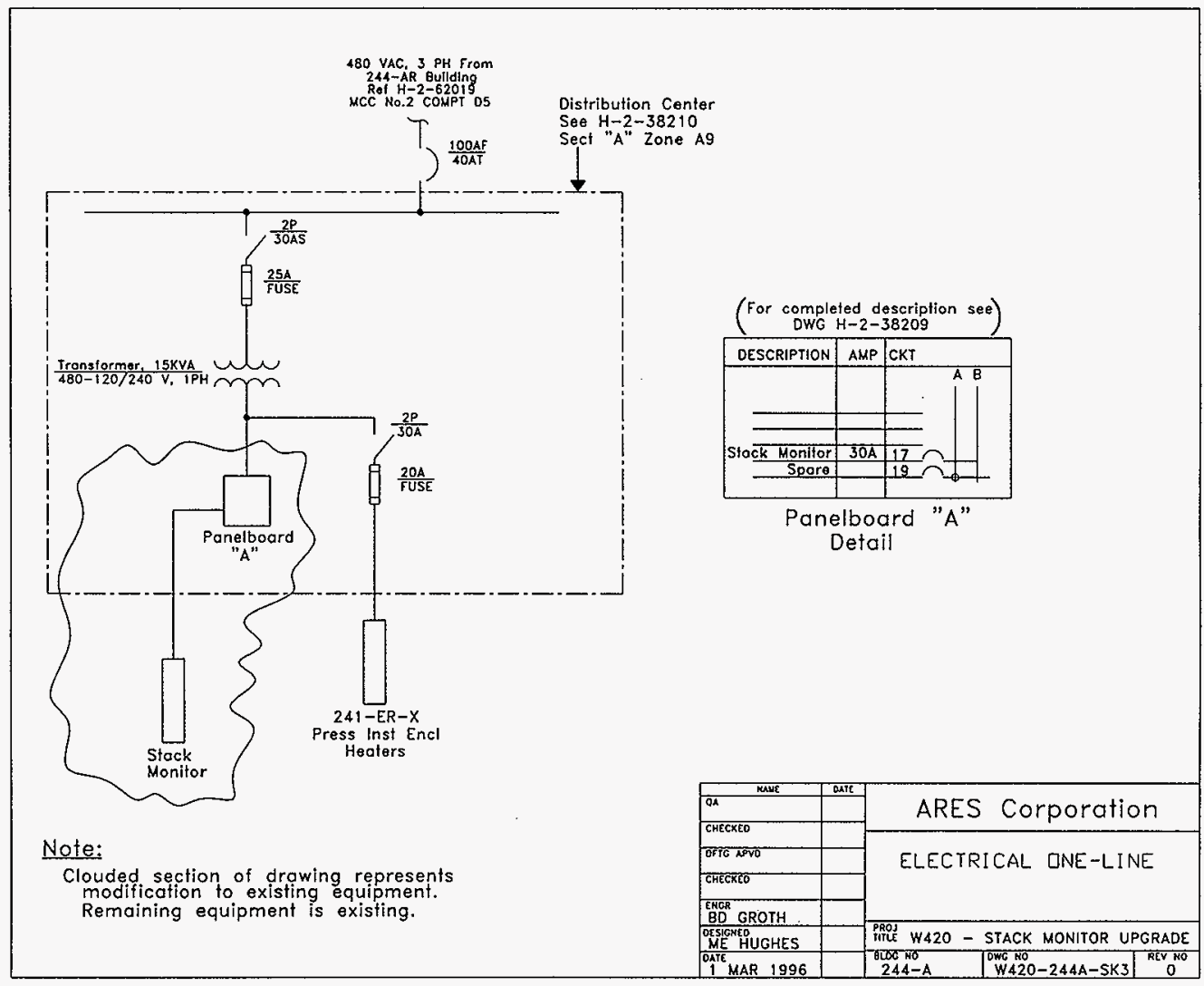




\section{Appendix I}

\section{BA/BO Schedule}


Project $W-420$ BA/BO Schedule

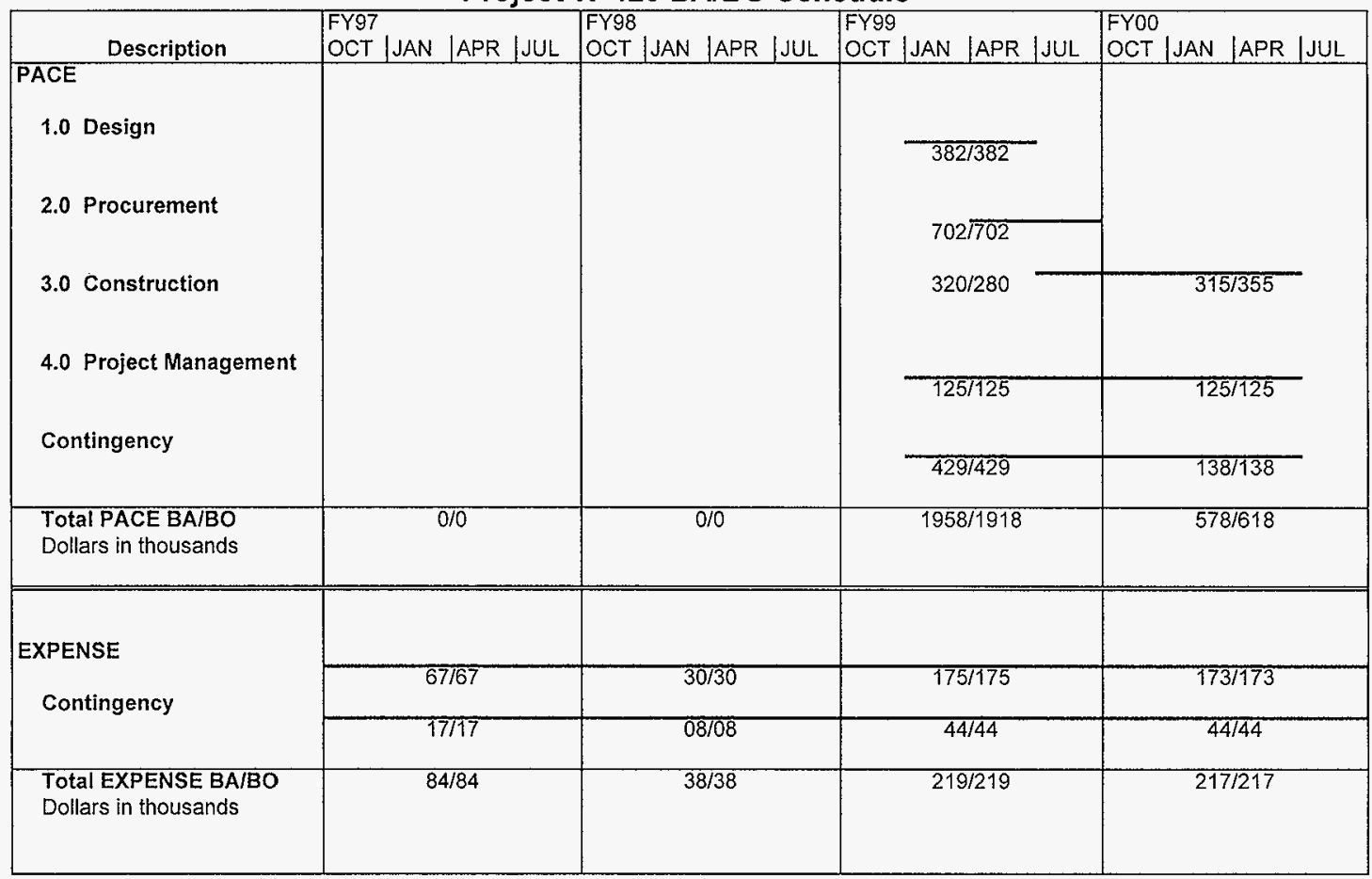




\section{DISTRIBUTION SHEET}

\begin{tabular}{|c|c|c|c|c|c|}
\hline \multirow{2}{*}{$\begin{array}{l}\text { To } \\
\text { Distribution }\end{array}$} & \multirow{2}{*}{\multicolumn{3}{|c|}{$\begin{array}{l}\text { From } \\
\text { D. T. Lott }\end{array}$}} & \multicolumn{2}{|l|}{ Page 1 of 1} \\
\hline & & & & \multicolumn{2}{|l|}{ Date $3 / 6 / 97$} \\
\hline \multirow{2}{*}{\multicolumn{3}{|c|}{$\begin{array}{l}\text { Project Title/Work Order } \\
\text { Conceptual Design Report for Project W-420, Stack Monitoring Upgrade/R4016 }\end{array}$}} & & \multicolumn{2}{|c|}{ EDT No. 614748} \\
\hline & & & & \multicolumn{2}{|l|}{ ECN No. } \\
\hline Name & MSIN & $\begin{array}{c}\text { Text } \\
\text { With All } \\
\text { Attach. }\end{array}$ & Text Only & $\begin{array}{c}\text { Attach./ } \\
\text { Appendix } \\
\text { Only }\end{array}$ & $\begin{array}{c}\text { EDT/ECN } \\
\text { Only }\end{array}$ \\
\hline D. M. Collado & AS-18 & $\mathrm{x}$ & & & \\
\hline G. M. Crummel & Rl-5l & $\mathrm{x}$ & & & \\
\hline W. E. Davis & $\mathrm{H} 6-2 \mathrm{O}$ & $\mathrm{x}$ & & & \\
\hline L.P. Diediker & $\mathrm{H} 6-36$ & $\mathrm{x}$ & & & \\
\hline P. A. Haine & R3-47 & & & & $\mathrm{x}$ \\
\hline L. D. Salsberry & B7.41 & $\mathrm{x}$ & & & \\
\hline M. N. Islam & R3-08 & & & & $\mathrm{x}$ \\
\hline D. T. Lott & R3-25 & $\mathrm{x}$ & & & \\
\hline D. L. Mitchell & H6-29 & $\mathrm{x}$ & & & \\
\hline Central Files & A3-88 & $\mathrm{x}$ & & & \\
\hline
\end{tabular}

